
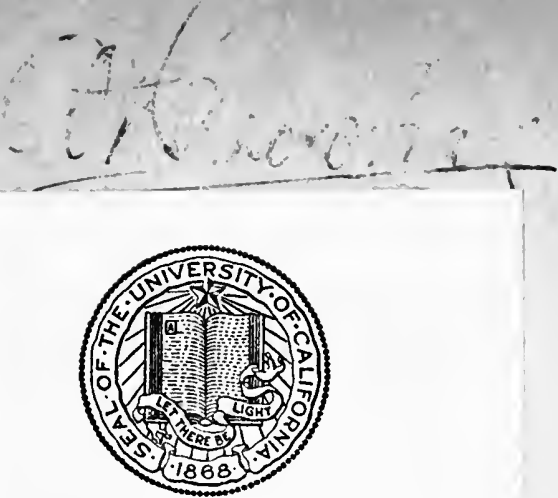

THE LIBRARY

OF

THE UNIVERSITY

OF CALIFORNIA

RIVERSIDE 



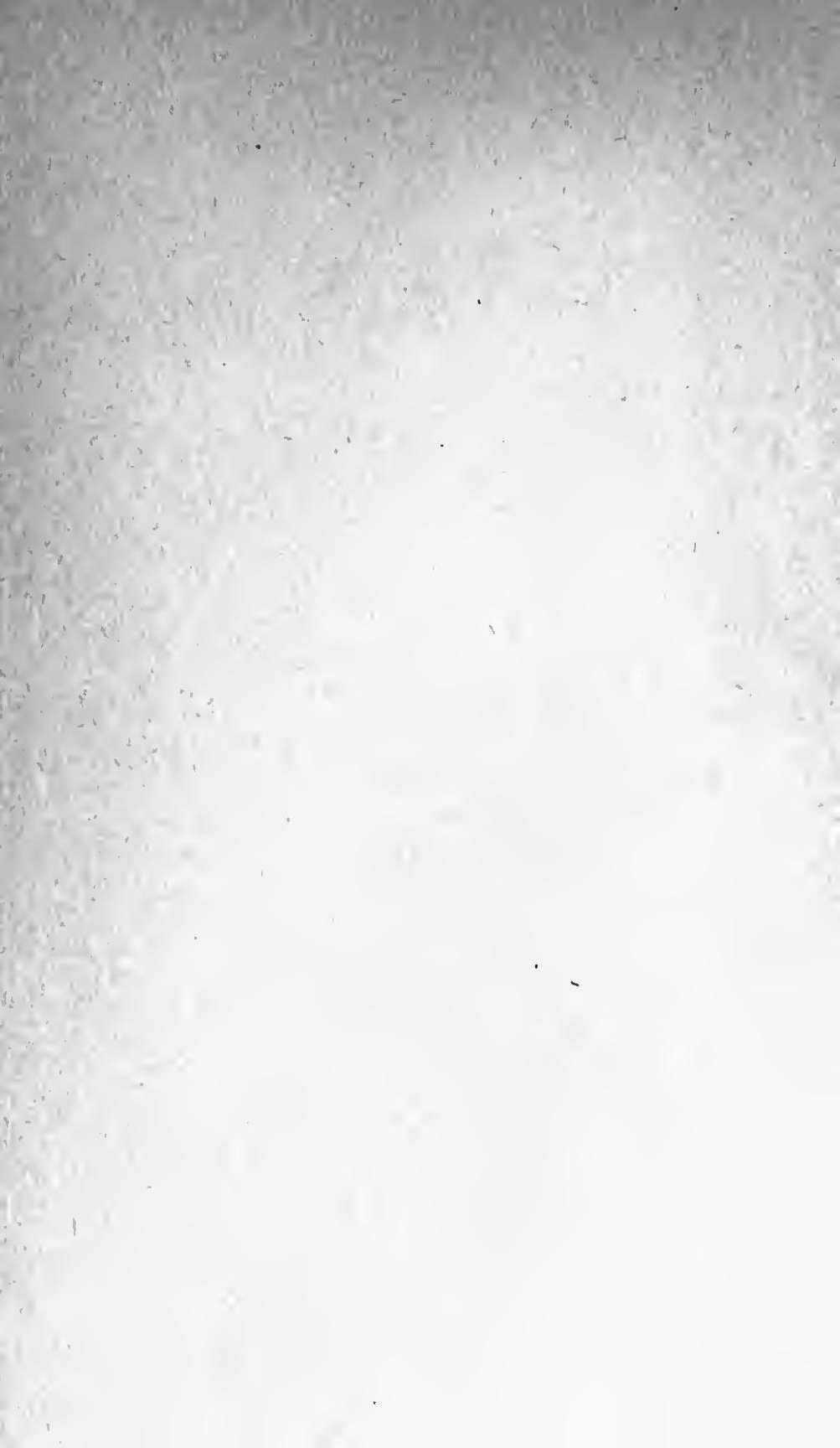




\section{LABOUR AND CAPITAL AFTER THE WAR}


Digitized by the Internet Archive in 2007 with funding from Microsoft Corporation 


\section{LABOUR AND CAPITAL AFTER THE WAR}

\section{BY VARIOUS WRITERS}

WITE AN INTRODUCTION BY

The Right Hon. J. H. Whitley, M.P.

EDITED BY

Sir S. J. CHAPMAN, C.B.E.

PROFASSOR OF POLITICAL HCONOMY IN THE UNIVEREITT OF MANCBISTER

\section{LONDON}

JOHN MURRAY, ALBEMARLE STREET, W. 


$$
\begin{aligned}
& \text { HC256.2 } \\
& \text { C } 5
\end{aligned}
$$

Finst Edition

Reprinted
Feb. 1918

- May 1918 


\section{PREFACE}

Changes in industrial organisation are common, particularly in countries where freedom is a reality, but, after the upheaval caused by the war, we shall probably find the changes of an age packed into a few years. If this should be so, the prospect of disorder will confront us-because things have moved too fast for our powers of adaptation-combined with the fear of misdirected effort, and even the danger of industrial war, because new ideas have been pushed beyond our capacity to assimilate them. With this in view, the design of the present book took shape. It was felt that nothing but benefit could result from frank discussion, in good time, of what was present to the thoughts of representative men and women with regard to the future relations of employers and employed-when the crisis is on us, the time for seeking the rational solution of problems will be passed, so that the best to be hoped for then, if we are unprepared, will be an opportunistic bridging of immediate difficulties. The response to the appeal for writers was gratifying, as the table of contents will at once disclose; but there were others who were only prevented from contributing by their absorption in Governmental activities, and it goes without saying that every limited selection of authorities must leave out many of the highest. For the rest, it is sufficient to say that authors, after having had the 
purpose of the undertaking explained to them, were given an absolutely free hand to deal with what seemed to them of outstanding importance. Some have been drawn by their argument into contact with issues that are at least controversial on sides that do not directly touch the subject-matter of this volume, and none of us, perhaps, can hope to have written entirely without bias, but, nevertheless, there appears to be a notable core of agreement in the opinions here expressed on labour questions even by those whose differences of view on other questions are well known. For a book of this kind, I conceive the task of the editor had best end with indicating its purpose, assembling its contents, and marshalling them with the reader's understanding in view. It may be added, however, in conclusion-as all my collaborators will doubtless agree-that the breaking of the ground, though well begun in these pages, is not complete, and that its tillage yet remains to be carried through.

S. J. Chapman.

January 1918. 


\section{TABLE OF CONTENTS}

Introduction-By The Rt. Hon. J. H. Whitley, M.P., Deputy Speaker of the House of Commons

Paga ix

I. By The Bishop of Birmingham (Dr H. Russell WAKEFIELD). . . . . . Social and Moral Unrest-Immoral Rest-Moral Unrest - Class Union-Sense of Discipline.

II. By.J. R. Clynes, M.P., Parliamentary Secretary of the Ministry of Food and President of the National Union of General Workers . .

Strikes and Lock-Outs - Strikes - Trade Unions Manual Service and Mental Service-Better Conditions for Workmen - Not Peace at any Price - Labour to elevate the Labourer - Works' Committees.

III. By LORd LeverhulMe . • • • .

Equalising Opportunities-Better Conditions of Life

-The Worker and the Drone-Employers and Employees - Service-Enterprise and InitiativeThe State and Commerce-Shorter Hours of Labour - Six-Hours Day - Long Hours and Fatigue Wages System-Co-Partnership-Intensive Production-Responsibility of Employers.

IV. By Adelaide Mary Anderson, M.A. . . Women in Industry in War-time-Substitution of Women for Men-Regulation of Hours of Labour -Women and Army Equipment-Industrial Migration of Women-Women in Men's Trades-Safeguarding Women in Industry - Welfare Department -Women and Education-"Woman-power."

V. By R. H. TAWNeY .

Radical Social Reconstruction-England and Economic Reconstruction-The Industrial Issues-Conditions of Economic Liberty-Industrial Autocracy-Trade Boards - Industrial Constitution - Industrial Reorganisation-Reorganisation of Industry - Industry as a Social Function-Municipalities and Profiteering - National Control of Industry-Efficient Production -Economy and Efficiency.

vil 
VI. By F. Dudley Docker, C.B., Past President of the Federation of British Industries . . Adaptability of British Trade-The Empire and Commercial Supremacy - Housing of the WorkersUnemployment Benefit-The Workman's Lot.

VII. By F. S. Butron, sometime Member of the Executive of the Amalgamated Society of Engineers. Possibilities of Industrial Harmony - Industrial and Works Committees-Ministry of Labour-Co-operation-Workshop Committees-Industrial Councils -District Boards-National Councils-The Strike Weapon-Raising the Status of Labour.

VIII. By Sir Hugh BeLL, Bart.

Legal Limitation of Hours-Minimum RequirementsCommerce implies Co-operation-Standpoint of the Employer-Increased Rates of Wages-Increased Labour Efficiency - Continuous Demand for Capital -Capital in Railway Enterprise-Managing Ability -Growing Demand for Capital-Employers' Attitude to Wages-Reduced Cost of ProductionWages of Furnacemen-Privileged Class among Workmen-Productivity and Wages-Effect of Restriction of Output-Employers and EmployedInterest of the Consumer-Distribution of the Product.

IX. By A. Susan Lawrence, Assistant Secretary of the Women's Trade Union League . . .

Women's Wages-Low Wage Rates-Regulation of Wages-Wages of "Substituted" Women-Legislation regarding Wages-Long Hours-Improved Conditions-Trade Boards.

Х. By B. Seebohm Rowntree . . . . 231 Capital and Labour-Level of Wages-Democratisation of Management-Departmental Councils-General Works Councils-Fixed Day Wage-Piece RatesProfit-sharing - Encouragement of Invention.

XI. By The EDitor

Piece-rates and Premium Systems-Sliding-rates-

Readjustments of Wages-Post-war Prices-Labour and Management-Security of Tenure-State as Mediator-Industrial Progress-Social Progress. 


\section{INTRODUCTION}

I comMEND this book to the attention of all thoughtful and patriotic men and women.

'The question of the capacity of our industries to adapt themselves to after-war conditions is a vital one. Unless in the days to come we can maintain and expand our product of manufactures in such quality and quantity as to provide exchange for our needed foodstuffs and raw materials, as well as to redeem our external war debt, we cannot hope to keep our place in the world.

In the application of science and in the machinery of organisation great strides have been made during the war; but these are dry bones without a solution of the problem of the human factor. The cause for which the war has been fought, and the tragic sacrifices it has involved, give a supreme importance to the human relationships of industry. Liberty will have been won, not by "man-power," but by "spirit-power." Liberty itself is only a foundation: to build on it a worthy and enduring fabric needs the same "spirit-power."

With a new sense of human values, we may hope to link all the workers in industry in a frank partnership for the common good. 'The safety of the State calls for the fullest development in a united purpose of all gifts of brain and hand.

The writers of these Essays approach their subject 
from different standpoints, but with a common aim. If the spirit that inspires them can reach and pervade all industrial leaders and thinkers, we may look with confidence to a new and happier "Industrial Age."

Mr Clynes, Miss Lawrence, Mr Button, and Professor Chapman have been my colleagues on a Reconstruction Committee which has made proposals for the setting up of Joint Industrial Councils and Works Committees representative of employers and employed in each industry and factory: I hope the present volume will do much to further the discussion of these proposals - which are here printed as an appendix.

J. H. WhitLey. 


\section{I}

\section{By The BISHOP OF BIRMINGHAM}

IT is unlikely that a number of writers would have been asked to collaborate in such a volume as this had it not been for the great war in which we are engaged. The scourge which is now being felt by practically every nation in the world has some benefit for mankind, though there will be for ever argument as to whether the evil of this great strife does not over-balance that which is wholesome.

It is well, at any rate, to discover, if possible, the lessons which the war has for us, and to make ourselves, through the teaching we receive, more useful to our fellowcreatures.

It is a great thing that every organisation dealing with the moral and social well-being of the people has been awakened into activity.

Not the least influence, perhaps indeed the greatest, has been exercised upon the religious communities. The various churches are seeking union, the one with the other, in order to promote the general well-being; and even those who are not adherents of any particular faith, but who have real human interest in their hearts, are ready to acknowledge what a force for human happiness and usefulness such union might be. 
Although the war may not end for some time, everyone realises that it has in some cases forced new problems upon our consideration, and in others it has revivified difficulties which, before, had seemed comatose, if not dead, and it is felt universally that preparation should now be made for the time of peace.

Probably our own Empire is the one which, when peace comes, will find itself engaged upon greater tasks than any other Power in the world. Although the United States of America may be regarded as the most youthful and most developing of world forces, the people across the Atlantic are, generally speaking, so far removed from European problems that the demand may not come upon America so much as upon Britain, to mould and fashion the civilisation of to-morrow. No one will deny that the youthfulness of England has been a remarkable characteristic of the last few years, and we islanders, and all our brethren in the various linked-up Dominions, have shown a freshness of outlook and a readiness in action which were hardly expected from us at home, but which may be said, without undue conceit, to fit those who live under the British flag for having a powerful voice in the decisions of the future.

If this be admitted, it behoves us to be thinking out how to face that which lies before. Added responsibilities of an extraordinary kind will be laid upon us, and a great. statesmanship will be necessary in order to deal with them. Our own people, especially our men, will have become imbued with many fresh ideas as to life. Young fellows who never dreamt, four years ago, of seeing much of the world far from their own doors, have learnt to know great countries of the East, as well as the continent of Europe. 'I'hey will have a widened conception of life, and much of their insularity will have been lost. They 
will expect to find the State at home a grander force than it has been in the past.

It is true that very many good lives which might have blessed England have been, and more will be, lost, but they cannot have died without having left some great example for those still amongst us-therefore one may hope that, though in some ways the young of our country seem to be at a loose end, they may. have had planted in them some seeds of noble patriotism, which, if the nation guides them aright, may make of them fine citizens.

But the social edifice is in a disturbed condition even in England. Many people declare that the only throne which will not have been tumbled over within the next few years will be our own, and assuredly, if ever a Sovereign deserved the increasing confidence of his people, it is our own devoted, though perfectly simple, almost over-unobtrusive, King.

But personalities, however admirable, cannot always restrain the feelings of an expectant and yet troubled democracy. The times have moved us all out of routine -we are seeing visions and dreaming dreams. Some of the enthusiasm of people is being exhibited thoughtlessly, and is being expressed in an undisciplined manner. The conditions of life during the past few years have been such as to make people disturbed, and possibly hasty in their ideas as to how their longings shall be satisfied. There is an unrest prevailing, and it is to that one point that this chapter in our book is directed.

My part in this work is to consider unrest from what I may call the moral point of view, and to suggest the kind of disturbance which there is in the minds and hearts of many people, and to try to help us all to satisfy the moral unrest, and to deal with, and defeat, all upheavals which have not a true foundation. 
In considering the moral basis of unrest, it is not out of place to begin by dwelling for a moment upon the immorality of a self-contented restfulness. Rest may be immoral when prosperity, due at least in some measure to the efforts of a great number of workers, is indifferent to everything save its own comfort; when, indeed, it does not strive to ensure that a fair share of its privileges and enjoyments shall be afforded to those who have helped to make prosperity stable and settled.

The bargain between employer and employed is not limited to the relation between work and wage. There must be on both sides a living and continuous interest. The unsatisfactory part of much of our present-day business is that there is no direct touch between those who profit and those who labour. In the olden days, the Head even of a large business had a direct interest in and took constant care of those whom he employed. He chose his apprentices, and treated them as members of his family; he watched the progress of his skilled workmen; he provided them with opportunities for bettering themselves; he made them feel that they were an essential part of the whole. Nowadays, such businesses have been turned into Limited Liability Companies, and the distance between the shareholder and the workman is so great that there is no personal touch whatever. How many of those who profit by our great Industrial Companies trouble their heads about the housing of the workers, the training of the children of their employees, the possibilities of recreation for those who labour, or, indeed, about any part of their life-story?

Such is the immoral rest of those who receive. There is also an immoral rest of those who earn. The man or woman living and working under unsatisfactory conditions, who is content to make no effort after better- 
ment, even when advised to do so, is living in a state of lethargy, bad for him or herself, and dangerous for the progress of the community. How difficult it is to rouse the sense of Divine discontent in the sweated woman worker who, through evil surroundings, has had her mental and physical vitality lowered until she is hardly a sentient being!

A third class of immoral rest is National indifference to social conditions unless immediate personal interest is concerned. We must not disguise from ourselves that it is not the majority of the population of this country that is inspired by the feeling, "I am human, and therefore all that concerns humanity is of interest to me." You have only to notice how careless people are as to political questions unless the shoe pinch. It is not the great moral issues that seem to affect men, it is whether they may have to pay an extra penny in the income tax or may have some restriction placed upon their liberty.

Again, there is the indifference as to national greatness. To many people, that country is the most important which is nationally richest-not over-great care is taken to see that national wealth is acquired by noble means. How many of our citizens base their political conduct upon such a foundation as that suggested by John Ruskin in the words, "That country is the richest which nourishes the greatest number of noble and happy human beings"? It is, unhappily, terribly common to find people extolling national privilege, and evading national duty and responsibility. Too many people go through the world ignoring their personal indebtedness to their country and their personal dependence upon even the meanest of their fellow-citizens.

A word or two now as to immoral unrest. Whenever a man or woman engages ill any crusade which is merely 
destructive or which is careless as to consequences, an immoral position is being taken up. Even if we are suffering an injustice, we must not attempt to remedy by any act which may be dangerous to the common weal, or of which we cannot see the natural end. In fact, any movement which is purely selfish and indifferent as to its effect upon others is anarchical and morally indefensible. Carrying this thought further, we may reasonably say that no effort after betterment should be purely sectional. Even if my unrest is the legitimate outcome of the want of consideration on the part of compatriots, I must consider their interests even when I try to secure my own. No isolated part of the community can really be permanently benefited by that which is hurtful to the rest of the citizens.

I think we may again say that the unrest which becomes active only in order to secure material advantage is lacking in the higher morality. I am well aware that the material may be used in order to promote the ideal, but that should be stated at the outset of any movement due to unrest. 'The greatest advance, I believe, in our labour leaders' methods is their ever-increasing insistence upon the right to live fully rather than secure the mere possession of more money for selfish purposes. In fact, we have got out of the old rut of narrow conception of what existence shall mean. Most of us still remember with some impatience the temperance orator of a past generation, who loved to produce his statistics proving that the giving up of a glass of beer every day meant so much more to eat or so many more pairs of boots. The teaching made no appeal to any higher. part of our nature; in fact, no nation can ever be permanently improved by an appeal to the material.

Having tried to clear the way as to what is immoral, 
may we not now get some clear knowledge as to the true basis of a righteous unrest? To begin with, it must be considerate of all. The human family has its spoilt children and its neglected ones. The State performs the part at times of a cruel stepmother, but the children have a duty each one towards every other. No person is ever really happy by an increase of personal prosperity which even shows a shadow of injustice towards anyone else.

Then, again, the moral unrest must be labouring for the development of the whole nature, and not merely for the improvement of a part. Human progress is the history of ever-enlarging and developing ideals worked out on ever-widening and more worthy lines. The really Divine discontent must be able to justify its divinity; it must show that it rises in order to prove that this world is God's world and not the world of the Devil. In England, at any rate, our social rising should be based upon the foundation that this country is Christ's country, and that IIis influence shall be specially felt where the world's influences would otherwise be most harmful.

Moral unrest sees oppression and calls for the loosening of the burden; it sees injustice, and it appeals for righteousness ; it notices the cramping of possibility, and it insists upon equality of opportunity; it dwells in a social atmosphere ignorant of or indifferent to the needs of the less favoured of human beings, and it forces knowledge and demands a living interest. Moral unrest, again, must be prepared to suffer for its cause, to be patient in its advance; the law of self-sacrifice is essential to all great causes. Christianity says to the social worker, "You must have your Cross before others can wear the Crown of a happy and useful life." Then, 
again, moral unrest will be careful not to lay too much stress upon getting, even for those who possess least and need most. Duty, after all, is the first thing in life ; our rights come only second. The ideal to be placed before even the humblest is, "What can I give to the world?" not "What can I squeeze out of the world?"

It is the experience of any man who has used a portion of his life in the study of the great social questions, that the interest in the fellow-man is greater in what are called the industrial classes than in any other part of the population. 'Those who have themselves struggled are most alive to the needs, most interested in the hopes, of their fellow-creatures.

A great wave of disappointment must surely have passed over many social reformers upon discovering that the delicately nurtured and more highly educated are often the least alive to human necessities, and yet it is not surprising; they have not been allowed to feel with their brothers in the world. When they are touched, they are the most useful of all workers. I go so far as to say that when we have inspired the general mass of our public schoolboys and university students with the spirit of Oxford House or the Harrow Mission, to name only two out of all the wonderful agencies now at work in London, and naming them only because, for personal reasons, they are so near to my heart; when, I say, we have imbued the mass with the knowledge and the feeling of the noble minority-then will union of classes be a reality, and social advance will be by leaps and bounds. 'The moral unrest of the whole nation is that to which we must look forward, and the signs, thank God, are hopeful.

It is curious to think that one cau go back to Confucius in order to get an ideal which is not alto- 
gether unsatisfactory for the twentieth century: "The perfecting of oneself is the fundamental base of all progress and of all moral development; the perfect man strives to perfect others also." The educated man who takes that precept to heart and uses the life of Christ as his example will carry out the whole duty of the citizen. Opportunity increases responsibility; it is not fair to expect the same ideals or the same methods from those who feel all through life the pressure of poverty, and who have not had the advantages of a full education and of a refined upbringing, as from those who have enjoyed all their time such privileges; and yet, as I say, we often get the highest aspirations from those who might be excused for being purely material.

The theory of Caste, as we know, is based in the East upon the ideal that those who are most favoured shall lead the grandest lives. Dare we look forward to the time when noblesse oblige shall mean that the man of culture, the man of wealth, shall esteem it the highest privilege to give the fullest service for the meanest souls? We have been accustomed for many years to the praising of England's middle classes-they have been held up to us as the most moral of our citizens, the most thrifty of our workers; nor has this been undue praise. But, at the same time, out of those very virtues, or some of them, has sprung a certain selfishness which is very often the handmaiden of the thrifty. The middle classes are the climbing classes; their goal is material prosperity. Industry is the essential quality. The unthrifty must be ostracised. Even religion was at times bordered north, south, east, and west by personal salvation. 'The less attractive features of the Puritan were distinguishing marks of these classes. To them there would not seem to be much that was attractive in the teaching-again $I$ quote 
Ruskin-" that the man's duty as a member of the Commonwealth is to assist in the maintenance, in the advance, in the defence of the State." I do not desire to condemn that great middle class-I want, now that it has/entered into its heritage, to widen its views of life's responsibilities.

Let me turn now to the thought of some Christian ideals which must belong to moral unrest. First of all, I note the words " unto this last." 'The curse of England, in the opinion of some people, is the improvidence of some of our workers, the unfitness of our people in the lowest social scales. The care for those who are in any sense unfit is a paramount necessity of our time; there must be continued unrest on this subject. Is it not a striking thing to notice that nearly all of the Anarchist Bandits tried in France and elsewhere in recent years were undersized, miserable weaklings? We must in this country realise that the Christ goes out to seek and to save those who are lost, physically and mentally as well as morally.

Another Christian principle is contained in the words, "Sirs, ye are brethren." 'Ihose who know what the country needs and who are desirous of improving matters must all stand together; no one class can sare any class; we are interdependent, and when we help the others we help ourselves. Another Christian principle I take from such sayings as "I will, be thou clean," "Receive thy sight," "Go and sin no more." Prevention must be the motto for all future social labour. Our legislative ideas, our crusades, must all have the destruction of all lowering propensities as their goal; it is not enough that we should relieve necessity, we must make completeness a possibility. 'Then, again, I would use the words, "If ye had faith." If we will get well into our hearts and 
minds the feeling that a living personal God rules this world, and that $\mathrm{He}$ is determined that the right shall prevail, and that we are indeed His instruments for the perfecting of humanity, we shall not be sluggish in our endeavours, we shall be brave in suggestion and in method. Workers with God! Once the social reformer, the man with the sense of unrest in regard to a nation's condition, has got this into his heart, there will be no faltering, there will be carelessness only as to what it may cost the worker himself; he will love to think of a world saved though he may be crucified or, what is worse perhaps, ignored.

I trust that the Church of Christ will regard her duty in this matter as the acquisition of knowledge, so that she may be of real influence upon the actual life of the nation, as the announcer of principles and the denouncer of any unprincipled action, as the great force by which national conscience shall be kept awake, and the teaching of her Lord shall be applied in wide and generous ways to twentieth century conditions.

How may we apply these general statements to postwar conditions?

One very obvious necessity of the future will be class union. There is no one who should understand better the natural unrest of the worker than the employers generally. A very large proportion of them are men who have become what they are through the determination which is the offspring of a worthy unrest. They know, most of them, the very feelings by which their more valuable workers are inspired, and, after all, it is the valuable worker who is the leader of the general mass. The good employer who has brought himself from comparative poverty to a high position, must have a certain sympathy with others who are anxious to climb, and he will realise that he can get better results out of men who 
are striving than out of those who are lethargic. It is his interest as well as his natural inclination to help forward the worker. The employee who has grit in him should admire the determination which has made so often one who started at the bottom of the ladder rise to the height of his capacity. On either side there should be understanding, admiration, sympathy, confidence.

This will be specially necessary when we revert to peace conditions. There must be dislocation of industry, and employer and employed will have difficulties to face. Both sides will have become accustomed to the abnormal conditions of the day; how will they face the problems of the future unless they stand together?

From what one may call the merely commercial point of view, the fullest energy will be required from all if we are to hold our own in the markets of the world. The German is not dead, and, as a poorer man, a partially overthrown man, he will have to buckle to in order once more to get a place in the sun. We have learnt, surely, that our own lethargy in the past has been one of the reasons why our competitors have, in many cases, defeated us.

We must have a wide outlook, and we must have a united country, instinct with the determination to succeed by right means, if we are to accomplish what I believe God intends of us in the future, namely, to be an example of high qualities, intellectual and moral, to the world.

We have all been admiring the patriotism of the war-time; let us not cease to be patriots when we can lay by our weapons.

Indifference to social conditions, and to national life, was the sin of a great number of people before 1914; this must never be so again. It was to some extent on 
accoun: of the striving for one's own good becoming the subject in which we were, each of us, absorbed, that many pecple failed to take a real interest in anything outside self. Whether it was the working-class longing for privileges which they thought their due, or the business man wishful to have his coffers overflowing, or. the religious body desiring to stamp the whole nation with its own mark, there was in each case far too much selfishness.

It is not only Government which is a trust from God, and which should be used for the advance of the nation; every individual life, if it is worth anything, should be, partly at least, a sacrifice to those around it. No man or woman should say, "I can be happy," so long as there is an unremedied national or civic disease. No man or woman should acknowledge that he or she is living at all, whilst they are making no effort for the furtherance of the general well-being.

Amongst the causes for justifiable unrest are such things as bad housing, lowering environment, absence of opportunity for recreation, a badly founded system of education, and such-like things. When people call out against these conditions they must be supported in their endeavours by the national conscience.

As for the religious communities, they must read into their prayer, "'Thy kingdom come," the meaning of establishing upon the earth such a state of existence as shall make people realise that there is a God ruling over the world.

One might place next to the union between people and the interest of all classes, one in the other, as a necessary qualification for England's future, the sense of discipline throughout the land. The great majority of our men, at any rate, and an increasing number of 
our women have been living under discipline for over three years. 'They have seen its value in the time of war; they should appreciate it for the days that lie before us. A nation, like an individual, if it is to work out its own salvation, and if it is to be worthy of its mission, must live under rule, and must not go just as it pleases. An unrest which merely shows that it will do as it likes, and seek its own ends in any way that may occur to it, is wishful for licence and not for liberty. 'The most perfect freedom is that which accepts willingly necessary bridling.

England had got somewhat out of hand before the war. She is now, on the whole, living in accordance with the requirements of a wholesome life, in which each tries to secure what is necessary, not only for himself but for others. 'This must continue. There must be a restoration of parental infuence. 'There must be means taken in regard to the young, that they shall know what it is to be a citizen, and to feel that one has only a claim upon one's country's privileges if one remembers one's own responsibilitics. The well-to-do must bear in mind that extravagant luxury on their part means, generally speaking, penury on the part of someone else. 'The people who are passed in the race of life must bear in mind that we cannot all accomplish the same results in our career. Everyone must seek to make the very best of his powers. We must beware to make the minimum that we can do, the goal of our ambition. We must regard the happiness of the civic life of the community as the greatest assurance of a peaceful land.

Social upheavals such as have taken place in other countries lately will never, I believe, come to England, if, from all classes, there is a willing acceptance of some such principles as we have laid down. Unrest will pass 
away; and under a free and enlightened Government it will be considered a delight to spend oneself for the well-being of the country, and to show England as a model of true life, so that the other countries who have wondered at her in war shall copy her in peace. 



\section{II}

By J. R. CLYNES, M.P.

This chapter is not being used to fire off suggestions for a social revolution, or to anger employers with an account of their exactions and misdeeds. Nor shall I try to please workmen with glowing testimonials of uniform good conduct. My object is to enumerate some of the common causes of strikes and other industrial troubles as they appear to one who is engaged every week in efforts to settle them. If causes can accurately be traced remedies may be suggested, however incomplete, as an absolute cure. Should we get that far, the parties who are represented by the terms Capital and Labour will be faced with the fact that reforms in industrial conditions and improved relationships for mutual benefit are possible only after both parties agree that each must forfeit something, not in order that either should lose, but that both should gain in a manner suited to the real needs of both. The gain of Labour must be substantial, and must be in the clear terms of money benefit and higher status. The gain of Capital might involve some loss of profit, but an immense advantage would accrue to the nation.

If the war does not change fundamentally the relations between Capital and Labour, it will at least 
tend greatly to modify in favour of Labour the basis of these relations. Before the war, Labour was in a very subordinate position, and Capital was regarded as conferring a favour upon workmen in providing them with employment. The war has shown to workmen that it is work which matters most. It is work which makes Capital. It makes wealth in times of peace, and in war it makes munitions, maintains soldiers, and it provides for a nation in the hour of its greatest need the services to enable the nation to continue the struggle for success.

Labour has been curiously elevated by the demands of the war, and has' on the whole stood the test which the necessities of the nation imposed upon its loyalty and its willingness to sacrifice. Here and there, there have been regrettable outbreaks and serious interference with the production of things urgently required. But apart from the merits of these differences, for which differences workmen at times may themselves have been to blame, stoppages often occurred, because workmen saw that employers and the Government could act quickly to settle a trouble when men were on strike, as compared with the indifference displayed towards their grievances while men remained at work. 'The speed with which a Government could interfere to stop a strike might have been used to prevent one. A strike was therefore invoked in some cases to hasten a decision.

The weapon of the Strike has not been used alone by the industrial section of the population. 'The betterto-do classes have, in pursuit of their interests, often employed similar means to obtain their ends and defend their interests. They have withheld their service, their products, or their money. Without the strike weapon, great masses of men would under existing conditions 
remain absolutely impotent, and would suffer not only material losses but serious humiliation and great injustice. For every one instance of the strike, even in peace times, hundreds of differences arising each week were settled by peaceful negotiation and such exchange of opinion as would permit both sides to see both sides. The strike weapon is not popular but is now-apart from the restraints of war conditions-more readily used when bad conditions due to long hours, exhaustive terms of service, or intolerable surroundings incline men to fall back upon any excuse for temporary respite from their disagreeable burdens. Experience has shown that workmen even in the mass are disposed to listen to reason if the attitude of employers, or that of a Government, is seen to be reasonable, and if the spirit of their treatment enables workmen to see that they are regarded as men as well as wealth-producers.

Long before the 'Irade Unions were strong, strikes were frequent, and very often failed in their object. The lock-out, for the purpose of the employer, was the counterpart of the strike instrument. In turn, each party used its own weapon, and now and then it was employed for ends which were quite insignificant when compared with the losses which a struggle sometimes involved. A lock-out or a strike would take place on some "point of principle," when, as a fact, the "principle" would be no more than a habit of mind, or some conception of personal dignity which induced men in authority who were accustomed to wield the power of masters to refuse to make any changes, not to say in things of substance, but even in matters of procedure.

Strikes or lock-outs of this kind cannot longer be tolerated, because stoppages have ceased to be the affair only of Capital and Labour. They have become the 
concern of a third and very large partner-the Public. Stoppages affect prices. They stem the current of trade through which public necessities are supplied. They upset the public mind. They foment prejudices and ill-judgment, and involve a wastage in the volume of both our mental and material resources. A strike, like a war, as such, is renounced by the universal desire of each side to put the blame for starting it upon the other. It is a thing to be disowned.

Blame for every industrial trouble is, by some writers, automatically fixed upon Trade Union officials. This is done in spite of all experience and evidence. Many of these writers completely ignore the fundamental causes of workshop troubles, and are, therefore, quite unequal to suggesting a suitable remedy. It does not avail to condemn "paid agitators" as the cause of the dislocation of trade. Agitation has always been the lever by which grievances are removed, and will be until there are no grievances to breed agitation. Every class and section has its staff of agitators, though scarcely any section other than the working class has to clamour for redress in a way to command the public gaze or arouse any appearance of general strife. 'The agents and representatives of other interests can move quietly and secretly, but still effectively, to advance and protect the interests which pay them well for their services. 'The Labour agitator must work in the open, and is frequently hampered by cumbersome machinery designed to leave in the hands of large masses of men democratic rights to decide what they will ask for, how they will ask for it, and whether they will settle on terms which may be put before them. 'The agitator, therefore, must never expect to satisfy those judges of conduct who write with the advantage of watching the coursc of events, 
and who gaily outline what men should have done after certain things have happened.

Look at the facts relating to the years 1911-14. Apart from a few indefensible stoppages, the spread of strikes during the three years before the war was undoubtedly due to the habitual unwillingness of employers to concede any better terms to their workers without those terms being extracted by force of Trade Union organisation. 'The cost of living for the industrial population had increased in those years far in excess of any increase in the workers' wages. So that, relatively, the workers were suffering under an effective wage reduction. During this time commercial returns and figures relating to trade and business showed a greater increase than ever in the volume and value of trade, together with enormous increases in the yearly incomes of the well-to-do classes. Many who are included in the well-to-do class work very hard and deserve the best that can be got. But it is equally true that there are thousands of rich persons who are as idle and worthless as the worst unemployed wastrel to be found, and it is true also that much mediocre service is excessively rewarded in the commercial and business concerns of the country. What we had, therefore, was this: that, side by side with regular proofs of Trade prosperity, there was an immense mass of impoverished wage-earners, doomed not merely to stay in a position as bad as they ever were in, but forced gradually, by the pressure of increased prices and growing distresses, to recede to a point where they would be even worse.

It is idle to blame the Trade Unions for the sudden outbreaks in which men demanded better wages. In the great majority of cases where vigorous claims were made Trade Unions never existed, and men lad not 
the guidance and the restraints of Trade Union agents. In some of these cases employers themselves took good care to suppress every attempt at organisation; but after such men as the seamen and dockers succeeded in securing improved conditions with little financial assistance from any trade society, it was no wonder that other men and women who had toiled submissively for eighteen or nineteen shillings a week at laborious work should spontaneously march out of their industrial prisons and struggle for better terms. The absence of Trade Unionism, together with the lessened prestige of many Trade Unions, which, in those years, some employers deliberately worked for, all tended to provoke those scenes of disorder which are ever the greatest enemy to the workers' interests.

'There is only one way to stop such strikes. They cannot be stopped by newspaper condemnation or by shrieking about public convenience. It is no use asking masses of men to sacrifice their personal rights for the good of a trade or the benefit of a public. Strikes can only be stopped when we remove the conditions which cause them, so that the sure way to keep a man at his job is to make it worth his while to stick to it. 'The greatest agitator is Injustice, and it is because of wickedly unjust conditions that men and women, whose conditions were little better than slarery, refused to go on with their tasks, even in places where the head of the agitator has not been raised.

Though it is long since the State legalised Trade Unions, many employers of labour, even yet, reject, not only with seorn but with studied offensiveness, the respectful approaches of Trade Union representatives who are known to be in search of peaceful settlements. Not a postcard of a reply can be wrung from some 
firms employing thousands of men, and even during war-time, many employers have declined in any way to set aside or modify their customs with respect to Trade Unions. They have expected, as quite the proper thing, that 'Trade Union practices and customs should be set aside in the national interest, and in their own also from the point of view of profit, but they have adhered rigidly to their former refusal to deal with the accredited representatives of Trade Unions. And they have talked of Trade Unions interfering with employers' rights, as though an employer had private property rights in the persons employed by him. Men who were merely pressing forward their own rights were answered by the statement that they were interfering with the rights of other people. The directors of railway companies used to say that the men's Union wanted to interfere with the companies' business. The men's Union merely wanted to look after its own business. It is the Union's business to represent and press forward the interests of its members. It is the business of the companies to manage the railway system. A Trade Union does not want to interfere with management, but the Union does want to discuss and settle the claims of workmen in regard to their conditions of service with the companies. The shareholders act through a body of directors who, in turn, act through managers, superintendents, and other officials. The workmen merely claim the corresponding right of acting through their executive, which, in turn, acts through secretaries and delegates. Differences about wages and questions of terms of service could neither be discussed nor settled by bringing together the mass of workmen and the mass of shareholders. The companies claim the right to practise the principle 
of association, and act through agents appointed for the companies' interest. The men only ask for a similar right of acting through their association, and through the agents whom they have thought proper to appoint. 'The men's agents are described as "third parties," but this description can be applied also to the chiefs of commercial and manufacturing companies, who are appointed by meetings of shareholders to look after their business. If the shareholders and the workmen are the first and second parties, managers and directors are as much a third party as are the officials of a Trade Union. There are so many employers who yet do not think so that these points require again to be stated.

There is still some confusion in the public mind because of the multiplicity of bodies through which organised Labour endeavours to act. There would be great advantage to Labour if the political and industrial claims and aspirations of workmen could find expression through one body; but the conflicting views of workmen themselves have so far stood in the way, and additional organisations are still being created.

Organised Labour acts through three national bodies. The oldest and numerically the largest of these is the Trades Union Congress. It has no financial obligations towards the 'Trade Unions, unless a case occurs which raises some important legal issue of general application to the whole movement. In that event the Parliamentary Committee of the Congress can make itself responsible for raising moncy to test any case in the Courts or in the House of Lords. Beyond that it has no financial obligations towards the various bodies attached to it. Its political duties are limited to endorsing or supporting candidates who may be put forward and approved by 
other Labour bodies. The General Federation of Trade Unions was fostered by the Trades Union Congress, and was called into being for purposes of more effective organisation, but more especially for the purpose of gathering into one national fund money whereby particular Trade Unions, in times of dispute, might receive financial support from the movement as a whole. The functions, therefore, of the federation were finance and organisation. The federation, however, has frequently gone outside these prescribed lines of activity, and has collided with the other Labour bodies. The National Labour Party was created by the Trades Union Congress, also for quite special duties. These duties were not finance or industrial action, but political campaigning and the oreation in Parliamentary constituencies of local bodies equal to running candidates and securing their success at the polls. It is because, in the discharge of these different services, there has been overlapping and misunderstanding of function that Labour has at times been found speaking not only in several, but sometimes in different, voices.

The disturbance of 'Trade Union customs, because of the war, will affect the question of future industrial peace, and we may well consider some of the issues thereby raised.

Nothing will be set right by forcibly setting aside 'Irade Union rules, or by calling upon workmen to forfeit the benefit of customs which are the growth of a generation or two. Such customs as exist are not singular to industrial life. They correspond to similar, if not even more rigid and profitable, customs, which in the higher trades and professions exist for the protection of persons concerned in them. Each other section is quite as ready as workmen in any 'Irade Union to defend its regulations and practices whenever these are attacked. 
And even during war-time these regulations and practices have been abrogated to a far less extent than in the case of the Trade Unions. Nor is anything gained by the State making such little concessions, and in such a grudging manner, as, for instance, may be cited by reference to the large body of postal servants and teachers. Both of these worthy groups of State servants have received far less in the way of material concessions, to balance the severe increases in the cost of living, than, say, railwaymen have received, and they had to wait much longer for whatever they have got. 'The feeling of "class consciousness" is fed by each tardy surrender of a small material benefit.

The class feeling, though it may not be very extensive, is extremely strong among men of influence and ability who are sprinkled amongst the masses of the industrial population. This feeling may be seen, when one at a large meeting of workmen touches a point like that covered in the explanation given by $\mathrm{Mr}$ Neville Chamberlain on how in National Service he would use the service of those who were not manual workers. 'The intention, he said, was: "To place all men in this class in a different category. 'They would not be required to go to the Employment Exchanges; special officials were being appointed to interview professional men in a separate place." 'The intention may be reasonable cnough, but the resentment that such a distinction in war-time arouses is well expressed, from the workers' standpoint, in verses written on this topic by W. N. Ewer :

Wherefore, whatever comes to pass,

Though Empires rise or Kingdoms fall,

Be it the dearest task of all

To guard the privilege of class. 
Though famine threaten these fair lands,

Beleaguered by a ruthless foe,

We cannot do a thing so low

As stoop to labour with our hands.

We will not wear the shameful yoke

Of servile labour ; come what may

We will not mix with common clay,

With coarse, ill-mannered working-folk.

Better to face, with head unbowed,

Famine and pestilence, than toil

With vulgar tillers of the soil, And all the low plebeian crowd.

We shall require to build a long bridge to span this feeling. Many employers of labour and men in the professions work hard; but there is an immense difference between hard mental service and exhausting manual service. Manual service includes none of the reliefs and pleasant excitements which brainwork brings to those engaged in it. The brainworker has a personal enjoyment, and at times a sense of delight, in his service. He is for the most part clean and fresh. His meals can be made an institution of the day. He has not to take his food in the dirt of the street or the mirk and smell of the workshop. The waiting-room of his office is a more restful place than many a working-man's home, and he receives tokens of respect and appreciation which lighten his daily labour.

How far will this class help to create the improved good feeling which must precede improved relations between employers and employed? Men of this class play a large part in the settlement of workmen's affairs. They can give us the required spirit and construct the necessary machinery for establishing better relations. Much can be done by systematic consultation and by 
a real discussion of points of mutual concern, instead of following the practice which is far too common of either side settling before a conference takes place what each side will do despite any discussion or the facts revealed in it. Men cannot be made to feel that there is a community of interest between themselves and employers unless the substance of that interest is reflected in material advantages or wage concessions when great rewards are reaped by Capital from conditions of exceptional trade prosperity.

'This claim on the side of workmen is not answered by asking whether they would submit to wage reductions in periods of depression. 'There is a level below which neither employer nor employed should go. 'That is the level of reasonable subsistence. In trade depression employers are not expected to go short of food and clothing, or to make material sacrifices comparable to the sacrifices often imposed upon workmen. There is a minimum of remuneration which in the worst of -times should be secured to workmen, and above that minimum they should in the best of times receive a margin of advantage from any state of trade prosperity. In the worst of times "the mutual interest of Capital and Labour" should save Labour from a state of starvation which capitalists never have to endure. Manual service changes Capital into greater wealth. Capital has the faculty to organise and direct the forces of Industry, and both must learn how jointly to produce, and how jointly to share fairly, the fruits of the service of both.

'The regulation of relations after the war will greatly depend on the state of the labour market which emerges when the war is over. Whatever that state may be, some effort should be made to reform the spirit in which the "labour market" has previously been viewed. 
Human beings are in that market, and a competitive price is not always the price at which their labour should be sold. Labour during the war was not remunerated according to the law of supply and demand. Labour in war-time consented to that law remaining in suspense, and in peace-time Labour naturally will resist the rigid application of that law should a state of depression be reached and the demand for labour fall. Continued sacrifice in national interests while the war was on cannot be rewarded by suffering in the interests of private employers after the war is over.

Should serious trade depression follow the war, it would bring in its train perhaps the same degree of industrial trouble as unusual trade prosperity might produce. Human nature has not been changed by the war, and perhaps the best thing that could happen in the national interests when the war is over is that there should be neither the extrene of depression nor the extreme of trade boom. The best condition "would be a sufficient and a steady demand which would incline representatives of both Labour and Capital to meet on terms which would give neither a great advantage over the other, and which would induce both to consider differences on actual merits far more than they have ever done.

But I repeat that no plan for improving relations can succeed which does not result in giving better conditions to workmen. Their advance in the scale of life has been considerable in the last generation, but it has been very small in comparison with the great headway made by the more favoured classes, who have added immensely both to their possessions of wealth and their power greatly to increase it. What was a fortune to the old-time emplover is but a moderate return 
to many a modern master. The exhibitions of luxury and the proofs of high living, the extravagance and the almost indiscriminate outlay indulged in by some of the rich and powerful, have afforded their full share of stimulant to the spirit of discontent shown in industrial centres in recent years.

Should systematic consultation with workmen and their representatives prevent a great deal of trouble, the Trade Unions are not likely to listen to any request to forfeit the right of men in the mass to cease work when other methods for securing redress altogether fail. The conditions of compulsory arbitration imposed by the Munitions Acts, in so many industries as a war measure, were submitted to by workmen and their Unions from motives of patriotism, and for reasons of national safety. 'The condition of things after the war may release a great deal of pent-up discontent, and arbitrators' decisions would not have the same effect on the minds of workmen collectively as they had during the progress of the war.

If through Parliament this phase of the industrial problem were taken up, the country might be able to purchase from workmen their right to strike in circumstances where a strike would involve serious public injury, should society be prepared to pay the necessary price. What would that price be? It would be not less than an ample minimum wage; far better surroundings in their employment; the guarantee of a fair share of the increased gains which flow from trade and business; some effective part in the control of workshops; and the certainty of absolutely impartial decisions by whatever courts of arbitration may be authorised to decide differences between Capital and Labour.

I do not say that there is in the Trade Union mind 
any great tendency to consider changes on these lines, and they are mentioned only in order to emphasise the reluctance with which organised Labour would listen to any appeal to change the relations between Capital and Labour on the lines of calling upon Labour to forfeit the use of the strike weapon. But some such conditions might well be discussed now. Anything on these lines would not mean, as in certain quarters is feared, that Labour would be compelled to have "peace at any price." It would more likely mean a tendency towards peace without the heavy price which both sides frequently pay for misunderstandings, and for a wasteful clash of interests which, at some time or other, have to be reconciled. Peace at any price is a condition which neither Capital nor Labour would permanently submit to; but as most of the differences which arise are now being adjusted without stoppage, even in circumstances where the atmosphere surrounding the parties is more favourable to strife than harmony, there is no reason to despair of plans being developed which would reduce to a minimum the loss suffered by all concerned from stoppages which rational effort could prevent. Judgments should not be reached nierely upon economic or industrial grounds. The domestic and moral grounds must be considered. The structure of better relations must be built upon conceptions of what industry can be made to do for its workers, and not upon what they can be compelled to do for industry.

Workers managed during the days of peace on low wages; they cannot subsist on low wages in view of what the war has produced. 'They not only cannot, but they feel that they should not if they could. Nor can high wages with high prices be any consolation. The subsistence level can be raised only as remuneration is made 
to rise above the immediate necessities of the wageearning classes.

Overtime and extra work above the normal week are not a remedy. Overwork in war-time was found not to be a remedy even for war production. Overwork in peace-time would not act as an economic saviour of commercial England. Illnesses, accidents, and physical burden are the companions of excessive labour. They do not in the end pay. And the employing class must not rest content with the spectacle of such housing conditions as millions of workers have to submit to. The tone and life-outlook of the industrial population can be lifted also by better and broader educational opportunities. But all these things hinge upon wages and workshop treatment, and the more wages are depressed, the lower down are the workers driven in the scale of ignorance, habitation, and conduct.

Mr Bonar Law, in one of his Budget speeches, said that, "One of the greatest hopes for the future of this country after the war is to be found in this, that, as the result of the way in which munitions have been produced in this country, we have revolutionised our whole industrial processes. We have scrapped not only old machinery, but old methods, and when the war is over there will be plenty of demand for any production which is available. In my deliberate opinion, the rapidity of the recovery of this country after the war will depend on the use we make of the new methods and the new machinery which have been introduced, and will depend, above all, upon the extent to which the old hostility between Capital and Labour can be removed, so that both can work together to get the best possible output in the national interest."

Here again is obtruded the idea that the first, if not 
the main, object of reconciling the claims of Capital and Labour is to increase output. That will more likely scare than convert a workman. As an argument it is fatal. What the workman wants to know is, whether we are to scrap the old ideas of working-class housing; the idea of making each worker into a mechanical producer only. Shall we bring to the front the idea of using labour for the great end of elevating the labourer? Hostility between partners will not be removed so long as the partners in industry are represented by the two extremes of depressing poverty and growing wealth.

It will not avail for one side to ask what the other side is going to give up. Even if both sides are expected to forfeit something, there is little in the way of exertion that Labour can give more than it gives already. Millions of people who work hard are at subsistence-level, when we make allowance for ordinary misfortunes-of illness, unemployment, and ill-luck. Many thousands of workmen, in the course of a year, find that by twelve months" labour they have only earned enough to keep them alive to go on working. Workmen could give up some of the restraints which they were taught by bitter experience to impose. But as most labour is already taskwork, with payment by results, this will not settle everything. Their masters were the first, unconsciously, to teach workmen how a bargain should be made. It was to give as little for as much as could be taken. Workmen, in order to live, were compelled to give what they had on the employers' terms. As the Trade Unions acquired strength, and the power to bargain collectively increased, workmen sought a remedy by fixing conditions to regulate production, not so much that output should be lessened as that reasonable conditions of ease and comfort at 
work should be secured. Whatever the results for either party, the men have only applied the doctrines of their masters.

War problems will not be settled merely by talking about what workmen will now have to do. Workmen are talking about what employers will have to do. Increased output from whatever cause must mean increased status and pay for both the skilled man and the labourer. Capital can yield for the national interest as much as Labour. Will Capital be content to take less as a reward, if Labour is to be called upon to give more as its share towards rescuing the country from any economic troubles due to the war?

Workmen will not take kindly to some of the proposals for using them more effectively after the war, as a more powerful economic lever for increased productivity, in order that commercial competitors can be more effectively faced. Speeding up the workmen scientifically is a task which several able men have taken delight in handling, but no considerable or permanent change for the better can ever result unless new schemes go back to the old idea of considering the workman as a human being. 'lo drive men by means of machinery or by scientifically arranged methods of production to efforts for greater output may merely rush them to a point where the limitations of human nature are certain to appear, and where a break-down of the physical powers is the result instead of increased output. Long hours and overwork, ligh pressure carried to too great a length, have too often meant illness, accident, and wastage, bringing gain neither to employer nor employed.

IVe cannot look for changes going beyond any point for which neither side is at present prepared. But no change will be accepted, not to say welcomed, by 
organised Labour, which is designed to secure first and foremost greater output, and not to secure better conditions and greater rewards for the producer. The producer ought to stand first and not last as one of the three great partners in any industrial nation. The public, the employer, and the worker have never yet been real partners, but the worker has now, by organisation and by a fuller understanding of his place in industry, established the means whereby, as one of the partners, he can exert, more than ever before, great authority to secure his fair share. He must be taken more frequently into the confidence of employers, not in order that secrets of trade should be revealed to him, but in order that matters which may well be the subject of common knowledge should be the subject of mutual discussion and settlement. 'The commercial and financial sides of a trading concern are matters for the directors and the management, but scores of other subjects relating to wages, hours, workshop conditions, systems of superintendence, terms arising from changes in production or new schemes of manufacture-these and such like questions are as much the affair of the workman as his employer. They are questions which can be settled fairly only if there are means and opportunities for discussion of difficulties as these matters arise. To this end there can be established (providing the right kind of atmosphere and sense of mutual interest in a workshop were created) representative committees in the works, acting generally for the rights of the men and the interests of the management. These workshop committees can be linked up with Councils for particular Trades operating in particular districts, and consisting of the most representative and the most competent men to be found on both sides. These committees would not be 
in revolt against some policy of their Union or exist in a spirit of antagonism to the employer. 'They could have regular meetings in the works and act with representatives of the Firm in settling differences arising within their clearly stated functions.

It would be easy to suggest more far-reaching changes. It would not be easy to get employers or workmen to accept them. It is idle to make proposals for better relations which we know beforehand go far beyond any preparedness for change on the part of the two parties. The essential condition from the Labour standpoint is that new methods to improve relations must not displace 'Trade Unions, but be supplementary to them. All the principal functions of trade organisations must be retained to them. Neither in importance, in service, nor in freedom to act, must 'Trade Union authority be diminished. But the scores of smaller matters which now consume the time of Trade Unions might well be settled inside the workshop. Small matters have often been the cause of great disputes. 'To end disputes we must end the spirit and the system out of which they grow. 


\section{III}

BY LORD LEVERHULME

'THE greatest wealth of the British Empire is its wealth in men and women. So measured, it is the most glorious as it is the largest, as well as the richest and the most powerful, Empire the world has ever seen. In laying the foundations of this Empire, successive generations have seen to the full equipment, in advance of all other nations, of our battleships, our mercantile marine. Our manufacturers have been progressive in the adoption of machinery, plant, and mechanical utilities, providing ample capacity for world-wide trade and commerce. Yet, through all the centuries, governments and citizens have been singularly indifferent to the human element in productive enterprise, to the housing and healthy living, and to the educational efficiency of that greatest source of all wealth-the British men and women who compose the Empire. The human element has been ignored, and human needs have been neglected. In vain has the poet sung -

How poor, how rich, how abject, how divine, How complicate, how wonderful is man!

Midway from nothing to the Deity !

Human beings are infinitely more complex than Dread- 
noughts or steamships or machinery or plant and mechanical utilities, and, being more complex, ought to receive the greater care and attention. Man is of the earth, earthly, but has genius and capacities that are of the heavens, heavenly. That great statesman, Gladstone, said: "Man is the crowning wonder of creation, and the study of his nature the noblest study the world affords." Emerson has said: "Man is a part of the universe made alive." Aristotle said, more than 2000 years ago: "Man is the metre of all things; the hand is the instrument and the mind is the form of forms."

When this great world's war is ended we shall have to face an entirely new world. 'The British Empire will not be the same Empire that entered into the war, nor will British men and women be the same. Just as every storm that sweeps over our rocky coasts, and beautiful woods and dales, leaves some changes and destruction in its path, so must this war, that has brought death and destruction on inmocent peoples, countries, and cities, change not only the face of Nature but the outlook, habits, and character of men and women, and leave the world a different world from what it was before the war. And it is the duty of governments and citizens alike to reconstruct the new, better than the old that has been destroyed.

We have now the immediate opportunity, based on good and wise govermment, of raising and improving the conditions of life for men and women by means of all those activities of production and distribution which we call trade and commerce, or business.

Now, the real true basis for commerce and business is service rendered to our fellow-man. This service tends to the welfare of the whole human race; and that nation is most successful whose service rendered by her commerce 
is the greatest, and in which the happiness and well-being of the men and women engaged in that service have received adequate, full, and proper recognition, not only in the way of education, but also in housing facilities and improved living up to the highest standard of health and comfort the age can yield.

It is merely so much pompous nonsense to talk of "reconciling Capital and Labour," and to prophesy that otherwise the Germanic Central Powers, after their defeat on the battlefield, will win a victory in trade and commerce. The days for "reconciling" Capital and. Labour, as ordinarily meant-if ever such days existed, which I doubt-have vanished in the smoke of war. To-day's programme must go much deeper than mere attempts to prevent strikes and disputes; it must include the placing of employer and employee on the footing of equal opportunities, and of sharing the profits of trade and commerce between all the three elements necessary for production, viz., Capital, Management, and Labour. The tool-user must become joint owner of the tools he wields.

How, on terms other than of equal partnership, can strikes and the old jar of clashing interests be made to disappear? Before the war we have been slow to realise that only by the assimilation and amalgamation of interests of employer and employee can we attain to finality in the prevention of strikes. We were so slow to grasp this truth that the fire of war had to be kindled under us before we could wake up and "get a move on."

But how rapidly rich and poor, Capital and Labour, have been drawn together and organised by this war in the production of war material! 'There is no question of "reconciling" Capital and Labour when the peer and working-man meet in the trenches, or when peeress and 
factory-girl meet in the munition factory-they have only one thought as co-partners in the British Empire, that of wholeheartedly working together for the production and distribution of munitions of war, to ensure complete victory over our enemies. And, just as we are a united empire to win this war, so we must be united, after the war, if we are successfully to reorganise our trade and commerce, and be prepared for after-war conditions.

There is vital stimulating work for the uplifting of the whole human race waiting to be done, and it would be nothing less than a crime if such a wonderful spirit of comradeship between men and women of all ranks and stations as this war has produced could not be continued after the war.

Let us make no mistake as to what this brotherhood and comradeship means. When a body of men strike it is not, as the newspaper articles and delegates' speeches would lead us to believe, merely a strike for increase in wages. It is true that an increase in wages is what is asked for, but what is really being sought is a general betterment of condition, a bigger share in the profits of industry, and a fairer share of the comforts, happiness, and well-being the world affords. Neither the strikers nor their leader's may. in their conscious selves directly realise this, but in their subconscious selves this is what they are seeking, and striking for. Labour demands much more than full wages and full-time regular employment. Labour demands, and justly demands, the best conditions of living, and sufficient leisure, not for loafing, but for the attainment of a higher standard of education and refinement, combined with opportunity for healthful recreation and leisure.

Arm-chair theorists and investment-holders ridicule the buying of "pianos" by working-men for their 
daughters, and talk loftily of Government taking "drastic" action to prevent strikes and lockouts and to "reconcile" Capital and Labour. Many of the men who so talk do no continuous daily toil. All they know about strikes is that they interfere with dividends; and therefore, from their point of view, strikes are always wrong. Instead of wasting time on their own personal point of view, let them get down to the hard facts of a life of continuous daily toil in the factory or workshopnot for a day or week but for a whole year. And then let them imagine such a career for a whole lifetime.

If we are to hold our own in the commercial afterwar struggle, we have got to study the employees' position, and realise that, just as sure as it is true that all play for any of us is bad, it is equally true that all work for any of us is also bad. The health of the employees requires that they must have reasonable holidays, not only in summer but at other times, and, in addition, the provision as already mentioned of better conditions of living.

And this climb upwards is only just beginning. Labour can never, so long as it is healthy and sound, be satiated with betterment conditions; and the fact that "much wants more" is the best guarantee of further progress. Comfortable homes, with gardens and baths with hot and cold water "laid on," are to-day rapidly becoming necessities for happiness, as they are already for health. Sons and daughters must be better educated. Drudgery and exhausting toil must be abolished and replaced by labour-saving methods and shorter hours of work.

All reasonable recreation and healthful pleasure-bringing inventions must be multiplied indefinitely as a necessary relief from toil, and brought within the reach of all. A new beginning must be made, and we must clear our minds 
of all muddle and prejudice and recognise the equal rights of all workers, to share not only in the work and the pleasure of work, but also in all healthful recreation and the pleasure of relief from toil. After the war reconstruction of our relationships on a higher level for Labour and of greater opportunity for Capital will be imperative.

The only sound policy for any government is to legislate for the truest welfare of the workers, and to legislate to the disadvantage of the drones and idlers of whatever rank or station. Each rank or station has its idlers and drones as well as its workers. The workers of all classes are entitled to the highest standard of welfare, comfort, and happiness the world can yield, short of enervating luxury. Pianos are not luxuries. They are as necessary in the home of the working-man as in any other home, be it castle or suburban villa. And it would not be :going too far to assert that they are even more necessary in the home of the worker, and certainly are better merited.

Every employee is not a worker, and every peer or rich man is not an idler. In obedience to the Divine law, Nature, whilst producing every variety of life, on land or under sea, in wood or field, creates only two sexes; and so, in the British Empire, whilst we can have all varieties of rank and station, of degrees of wealth and intelligence and strength, we can create only two classes-those who do their duty and those who fail to do their duty. We have an Empire big enough to contain, and which must contain if we are to attain success, every variety of rank and station from our King and Queen (than whom none set us a greater and more stimulative example of devotion to duties) down to the youngest shop-girl and errand-boy. But not even the 
world itself is big enough to hold more than the two classes-those who do their duty and those who fail to do their duty.

This good old world has no use for the idle rich man nor the idle poor man. Those who work and do their duty are the peers and equals, in the sight of all honest men, of any occupying the most exalted rank or station, and can meet those of the highest rank on terms of absolute equality.

The division which includes the rich drones and idlers - those possessing wealth who fail to do their dutylove to be told that the Trades Unions and the workingman are ruining the country, and that the nation is "going to the dogs." Equally, the working-men division of drones and idlers love to be told by their stump orators, and in their papers, that they are being wronged, and that some impossible division of the wealth of others amongst themselves would be the "cure all" for the ills of life.

It is so much more agreeable to any of us to be told we are being wronged by others than to be told we are being wronged by ourselves in our own habits and selfindulgences! We are slow to learn that our woes and sorrows are the direct result of our own laziness, improvidence, and general failure to do our duty in life. Pandering to the lazy is more popular than straight talk to them. The loafer type, of whatever class, is always ready to believe ill of his fellow-man. If this type be rich he believes ill of Trades Unions and employees. If the type be an employee he believes ill of the so-called employer, and is under the conviction that employers have a very easy, lazy existence.

How are we to make the average employee realise that the so-called employer is, in every successful business, 
one of the hardest worked of men? The employer's work, however hard and continuous it must be, is mental work and nervous strain, and therefore is not directly in evidence or easily understood. The only way which this error can be discovered is by both having closer contact with, and knowledge of, each other-just as we have seen that both have better understood each other by working together during this war in the trenches and in munition factories and on committees.

The false god "Ca' Canny," which is really a war lord, is as futile to achieve betterment for its worshippers as the Kaiser has proved himself to be, and must as inevitably bring about the wreck and ruin of all its worshippers. But employees must no longer be exploited for the benefit of the employer, nor must the employer continue to view labour merely as its "hand." Nor must the employer be deprived of reasonable reward by some false economic ideas of labour.

We cannot continue to live in a world of false ideas as to production. Labour must come to know that if wages and betterment are to be increased, production must also be increased. Capital must come to know that low wages and poor living produce inefficient workers with high costs.

It is possible and essential that we should have the highest scale of wages combined with largest output, and lowest cost of production combined with the fullest share of profits to the workers, as a sound basis for our industrial system.

Combinations of either firms or workmen mercly represent growth and development, but combination of either Capital or Labour of firms or of groups of firms, of workmen or of groups of workmen, can only succeed when such combinations enable better service to be 
rendered. The first sign of this growth of business was when firms added branches and other trades to their original enterprise in order to strengthen and cheapen their output, or to lower their-general expenses: such as when certain iron-smelters became makers of steel, then rollers of plates, then shipbuilders and marine engineers, constructors, and so on. Then followed the grouping together of firms carrying on the same business in order to strengthen themselves. Thus concentration was realised, and cheaper production resulted; and also, by the sharing of risks, greater security was attained. 'The supply of the raw material for the cheapening of costs of manufacture by the interchange of technical experience and the sharing of statistics and knowledge is regarded by all combined firms as their greatest aid to cheaper production.

All combinations, whether of employers or of employees, should be open and above-ground. To force combinations of employers or employees to be secret, or to drive them underground by an attitude of antipathy or active opposition, would be against all public interest.

The next stage in development and growth of production must be combinations of employers and employees. This would be a logical development in the efficiency of service rendered to the consumer, and it is necessary for the avoidance of waste in production and distribution.

Any attempt to make undue profit by combinations of employers and employees, or of either, or of both, must mean the throwing away of all the advantages attained by combination, and the inviting and strengthening of competitors. Thus, if after a 5 per cent. economy were effected in the cost of production by the economies of a combination, and the combined firms were to attempt 
to appropriate this entirely to their own benefit, and much more were they to attempt to increase their original margin of profit, they would at once lower themselves below the level of their feeblest competitor, who could undersell the combined firms, and would undersell them. The most that any combination can hope to accomplish is, by means of economies, to reduce cost of production and distribution, and be able to retain some portion of this economy-at most half-and thereby benefit themselves. The other half must inevitably go to the consumer. On any other basis the combination would be a failure.

I merely mention this to dispel the alarm that is felt in some quarters against any and every possible combination. It is only on this basis, namely, the sharing of the savings effected by economy in production and distribution with the consumer, that any combination can attain to permanent success.

Our future after this war depends on our bringing together, for the service of trade and commerce, our best ritizens of all ranks and stations, willing and anxious to do their duty to their country and to each other. The development and education of men and women of capacity and efficiency, of energy and persistency, of courage and initiative, must be the nation's aim and care; for on the welfare and happiness, and on the betterment and advancement of all such citizens, depends our future. If this aim cannot be accomplished, then there can be no soundness in British trade or conmerce, or security and permanency in our industrial position.

'The welfare and happiness of the men and women who perform the daily round of work and duty, monotonous and laborious, in the office and in the factory, in the laboratory and in works, in the shipyard 
and on the ships, in the school and in the shop, in the city and on the farm, must form the bedrock and strongest basis of British prosperity.

We must put heart into the workers of all ranks, and not artfulness into tariffs. And we must never lose sight of the fact that the true basis for success in all businesses, as for all relationships in life between individuals and nations, is comprised in the one word "service." Without this foundation there can be no permanent success in commercial intercourse.

There can only be one ending of this war-the unconditional surrender of the Germanic powers. But the German defeated in this war will not be the same German who entered with a light heart and truculent swagger into war. He will be a wiser and a sadder man, and more than ever devoted to science and industrial research and the advancement of trade and commerce. He will not have surrendered his natural aptitudes for plodding work and a hard life of frugality and economy. It matters nought what may then be the financial position of the Germanic Powers, nor even if they are practically bankrupt, so long as the individual German retains and practises the above natural characteristics and aptitudes. A very few years will suffice to ensure Germany her financial recovery, followed quickly by her full and complete industrial revival and efficiency.

But neither will the war leave the British race and the British Empire unaffected, or the same happy-go-lucky people and Empire that entered on this war. The echo of the guns has resounded from France, north to south, east to west, throughout the British Empire, and been heard by the backwoodsman in Canada, and the squatter in Australia and New Zealand, and by Boer and Briton alike in South Africa, by Hindoo and African, and has 
welded all into one great Empire irrespective of race or creed.

Within this Empire we possess every soil and climate, every mineral and forest growth, required for food and clothing, for trade and commerce, and for a full, complete, happy life. The British Empire occupies this unique position. Nature has dealt her a winning hand, and all that we Britons are asked to do is to play the game and to prove ourselves worthy of this heritage. We must make ourselves strong in ourselves, in our men and women, in the education of our children. Our Empire is too world-wide to be held together by tariff walls, and the British race is too few in numbers to be able to afford to neglect the making of each British boy or girl the best educated and the most efficient unit of humanity the world possesses.

We have nothing to fear from forces outside the Empire, but we have every reason to be alarmed at the "muddling through" British methods within the Empire. We Britishers can only ourselves injure ourselves-others are powerless to injure us if we are true to the abilities, intelligence, and vitality with which Nature has endowed us, and are true to ourselves. Whatever advantages the German manufacturer and trader has possessed over the British limufacturer and trader are advantages of superior organisation for trade and industry, and of superior technical assistance given him by his Government.

To the extent that the German Government has raised tariff walls round Germany, to that extent the German Government has weakened and enfeebled her manufacturers and limited and restricted her commerce. 'Io the extent that the German Government has provided an improved consular service, and has insisted upon German banks giving reasonable facilities to her manu- 
facturers and merchants, to that extent she has assisted and aided the expansion of her commerce. To the extent that she has had a more scientific and more modernised system of education for her children, she has supplied her manufacturers and merchants with a more efficient staff to carry on her industries. 'To the extent that she has gathered together, for commercial uses, more accurate and more detailed information as to foreign markets and foreign commerce by means of a better consular service, she has aided her manufacturers and merchants. To the extent that she has fostered cheap capital and ample facilities for her steamship companies to provide better and cheaper ocean transport facilities to and from foreign markets, and has provided cheaper and better rail and canal transportation facilities for her home markets, to this extent she has greatly helped her manufacturers and merchants, and the world-wide ramifications of her commerce.

I am confident that the British manufacturers, merchants, artisans, and workers have nothing to fear from Germanic or other races in competition for commercial prosperity, provided they continue to enjoy the advantages of Free Trade and obtain from our own Government equally efficient services. There never were any grounds for fear of competition at any time, from the days of our merchant adventurers to the present timeand it is unthinkable that there ever would be-arising from lack of enterprise or ability and initiative on the part of the British race.

We hear a great outcry in the Press at the present time as to this lack of enterprise and initiative of British manufacturers, as compared with German manufacturers, in the founding and development of the great aniline dye industry, but it is not generally known that the basis 
of success of the German aniline dye industry was the provision by the German Government of cheap industrial alcohol, without which that industry could not have been founded at all. The German Government met the demand of German manufacturers by providing facilities, free of excise taxation, for the production of cheap alcohol, whilst our British Government denied cheap alcohol to the British manufacturer, notwithstanding that deputation followed deputation explaining the whole position to the Government of the day, and asking that industrial alcohol be made free of excise or of duties.

For more than a quarter of a century Chambers of Commerce had pressed on successive British Governments the absolute necessity for the removal of this handicap, but all in vain. At last, about ten years ago, when the industries dependent upon cheap alcohol had been firmly established in Germany, and whilst our present Premier was President of the Board of Trade, our Government conceded this necessity. But, alas! it was then all too late. Similar instances could be cited in other industries, notably in shipping. Does the reader know that, two years after the present war began, as recently as July 1916, at the Congress of Chambers of Commerce of the United Kingdom, it was still necessary to pass a resolution which contained the following:-

"Welcome statement . . . that no privileges should be given to foreign shipping which are not enjoyed by our own."

Just fancy the handicap of conditions still existing that make it necessary to pass such a resolution.

'The German shipowners have won their position in the shipping. world by the aid of every advantage that the German Government can give to them, including Free 
Trade in materials and supplies for shipbuilding. The German Government have granted heavy subsidies to German shipping, have provided cheap capital, whilst British shipowners, in the year of grace 1916, had still to ask that our own British Government should not supplement the advantages given to the foreign shipowner by foreign governments, by adding thereto British port and other "privileges" denied to the British shipowner.

Not one single request of the British Chambers of Commerce at the Congress held in 1915 and in 1916 has yet been granted by our Government, so far as my knowledge goes. British manufacturers, merchants, and shipowners have to endure these handicaps, and have calmly to listen to the vapourings of the British Press, depreciative of British ability, initiative, and progress, virtues which the British Press claim are possessed in a supreme degree by their German competitor, who is held up by that Press and a certain class of orators as a super-man in business.

Germany's submarine war-in addition to its obvious use as a means to their hoped-for victory in this warhas also the objective of winning commercial advantages for German shipping after the war is over and the struggle for commercial supremacy recommences.

Our brave soldiers have dispelled all the theories of their depreciators as to the superiority of the German army and soldier as compared to the British army and soldier, but we all know that our brave soldiers could not do so until they were fully equipped and supported. by all the forces of the Empire completely organised, and extending from the man and girl in the munition factory to the soldier in the trench and on the battlefield. Give British manufacturers, merchants, and working-men an equal support and organisation, from the British 
Consul and British banks to the factory and office, and they will equally show their superiority.

It is stated that the German Government has to-day not only a War Cabinet, but also a Peace Cabinet, composed of nine of the most expert business men the German Government can secure to solve the industrial problems, and provide for the expansion of German commerce from the very moment the Treaty of Peace may be signed. The Germans are quite aware that, after all, their commercial revival will depend upon their banking facilities and their efficiency in chemical science, engineering skill, organising ability, on their fleet of merchant ships, and their well-equipped factories.

Tariffs cannot assist the shipping of any nation. On the contrary, tariffs defeat their own aim, and are not a protection but a hindrance to the establishment of a mercantile marine. It is an entirely false idea that tariffs can assist world-wide commerce and shipping, or that they are the characteristics of resourceful, progressive nations. Suggestions as to tariffs generally come from the nervous and the timid, or the inefficient. It does not make for strength for a government to assume the rôle of guardian, controlling activities and spoon-feeding with tariffs. The greatest pride that the British manufacturer can have is to be citizen of a nation that has maintained its pre-eminent position in world-wide commerce without the false aid of tariffs. Protective tariff's weaken, not strengthen, the vigour and resisting power of manufacturers. 'The basis of the call on government for tariffs is: "Do not expose us to open competition. Do not let foreign manufactured goods enter freely, and so permit the foreigners to match their brains in competition with ours."

'The only solid help any govermment can give to the 
manufacturer, merchant, shipowner, employee, and citizen is a sound educational system, efficient consular service, sound banking facilities, and good government, with equal opportunity and justice for all, and a system of taxation of wealth that will tend to its fairer distribution. This last is absolutely impossible under tariff conditions.

But, under the present system of hours of work, the thorough education of our children is practically impossible. An absolutely essential step in the direction of a more efficient educational system is the shortening of the hours of labour and the improving of the conditions of living for the worker.

The attempt to continue education to eighteen years of age by means of attendance at evening classes can only result in failure. These evening hours ought to be free for reasonable recreation, which is as important to the development of the growing boy and girl as facilities for education. The better organisation of the hours of labour must be undertaken in order to provide the facilities required for education and training during adolescence. By this means only can we produce good citizens, efficient workers, expert foremen and managers, and provide a ladder from the Board School to a complete and thorough education.

We are only just beginning to make a considered study of the inefficiency and resulting waste that is produced by fatigue. We cannot claim even yet that we have any very profound knowledge on the subject, but the wastefulness of fatigue has been abundantly proved by the researches already made, which have established the fact that fatigue requires more than $t$ wice the time for rest that was consumed in the excessive work that produced the fatigue. And again, that double such fatigue requires more than double again the time 
for rest to restore to full working efficiency. The effect of fatigue, therefore, is to produce the necessity for long periods of rest. Therefore, it is essential that work in the factory, the workshop, and the office should be so arranged as to avoid fatigue, and, by maintaining the general health of the workers, to enhance their activity and increase their skill and efficiency.

Moreover, modern conditions of production requiring costly plant, machinery, and factory buildings make it obvious that such division of the twenty-four hours must be made as will (whilst utilising the mechanical utilities to their utmost capacity so as to get as large an output from plant, machinery, and mechanical utilities as possible) tend to relieve the human element from fatigue. Only by so doing can we reduce to a minimum all overhead charges for interest, depreciation, and rent, etc., etc.

Recent reports of the Committee under the chairmanship of Sir George Newman, M.D., as to the effect of industrial fatigue on efficieney, record some most startling ascertained facts, and show that where fatigue has been avoided the production has been increased in the week by from 50 to 100 per cent. or over; also that the increased productive capacity of the workers can be assured when their work is varied and their interest maintained as well as their fatigue avoicled.

From this it is obvious that when our modern industries are run on a less fatiguing system of, say, two shifts each of six and a half hours with half an hour off for meals (making six working hours in fill per day), the efficiency of the worker by thus avoiding fatigue can be increased by at least $33 \frac{1}{3}$ per cent., and consequently that as much work can readily be done in sis working hours as under present conditious is done in eight. But 
in addition to the ability of the employee to produce as big an output in six hours as is now produced in eight, there would be the added advantage that the plant, machinery, etc., would be running for 50 per cent. longer time, viz., twelve hours instead of eight, which running of machinery would reduce the overhead charges proportionately, and increase the output enormously.

At the close of the war we shall be in a unique position to try this experiment as a nation. We shall want all the output of manufactured goods we can produce. We shall not have immediately the power largely to increase our plant and machinery. We shall have the return of our heroes from the field of battle; therefore we shall have ample supply of labour to test the experiment. The world's demand for manufactured articles after the war will be overwhelming and unprecedented, and in many industries will entail working machinery for twenty-four hours. This can be done without fatigue or strain by four shifts of six hours each, and this would enable us to maintain, when the war is over, our present industrial position. But in addition to this advantage to our industries it will give us an opportunity of a sound, efficient, and healthy educational system during adolescence and early manhood and womanhood.

The six-hours working day does not mean some hours gained for loafing. It is not intended to produce a loafer's paradise within the United Kingdom; and I say, without hesitation, that there is not a single man or woman of those who would be benefited by a sixhours working day who would not feel insulted if he or she were thought capable of viewing the proposal in that light. A six-hours working day will enable our educational system to be extended from the time when the boys 
and girls leave school at fourteen. They could work for six hours in the factory, workshop, or office, or elsewhere, and two hours at continuing their course of education, which education will include physical training and development. This will expand as their age progresses until at the age of twenty-two they will have had an opportunity of acquiring an education of mind and body which will be superior to that attained by the average of students attending Oxford, Cambridge, or any other of our Universities. From twenty-two to thirty both will still continue their education. The men will receive military training and drill and gain in physical development, and the unmarried women will learn sick-nursing and household management and other useful occupations. Thus the extended education which will have commenced at the age of fourteen will be continued until the age of thirty, and so equip the United Kingdom with supercitizens, who will be our best protection from any threatened attacks on our commerce or our country. After the age of thirty we shall have produced citizens efficient and fully equipped by education for all the duties of citizenship, and able and willing to take an intelligent, sound view of duties and responsibilities, of rights and obligations.

As a factor tending to increased output in factories, it is interesting to note from a report of the Committee for the Health of Munition Workers that variation of hours of work has resulted in increased production; for instance, in continuous employments the change from day work to night work has given better results than when the same employee was being continually engaged on day work or continually engaged on night work. Under the six-hours working day this condition of variety would be assured. 'The employees who worked 
one week during the morning and attended their educational or training classes in the afternoon, in the next week would be attending their educational or training classes in the morning and engaged in their usual employment in the afternoon.

It is clearly proved from these reports that long hours, with overstrain and fatigue, are big wasters of efficiency. All waste is a needless and expensive addition to the cost of production. But, even if the reverse were true, we are bound as a nation to take a broader view of this matter than mere cost of production. If we are to hold our own as a nation we have to look to improved conditions in the life of our workers, and we shall find, in doing so, as in all affairs of life, that the right and proper course is the best for us to take, in order to attain to greater efficiency and so cheapen the cost of production, whilst enabling us to pay the world's highest rate of wages, and to provide the best world's living conditions of comfort and happiness.

But we must never lose sight of the fact that foreign purchasers will not care a brass farthing, when the war is over, whether they buy their goods from Great Britain, who has fought to free the world from the tyranny of militarism, or from Germany, who has laid upon Britain and her Allies a load of debt in resisting the Germanic spirit of militarism. Foreign purchasers will care nothing for the education, well-being, and welfare of the British worker, but foreign purchasers will care, and care keenly, that they buy their goods where they can buy them best and cheapest.

It is not possible, therefore, to lay too strong emphasis on the fact that improved conditions for labour and shorter hours with higher pay, by means of increased output, must not only tend for the well-being of the worker 
and of the citizen, but must also, if their continuance is possible, tend in the direction of the cheapest cost of production.

But not only is a complete system of education and of short hours essential. It is equally true that it is essential that employer and employee, Capital and Labour, advance together in a spirit of mutual confidence and co-partnership.

Whether this can be accomplished remains yet to be seen. Suspicion and distrust on both sides lie at the very root of the present relationship between Capital and Labour. To remove this suspicion and distrust will not be an easy task, but it must be removed if we are to reap the full advantages of our opportunities.

I do not believe that any action, mild or drastic, taken by our Government can compel a spirit of sweet reasonableness to prevail or bring about the elimination of strikes. All the Acts of Parliament and of arbitration tribunals that can be created are useless unless Capital and Labour are combined in partnership and have equal opportunities for sharing the profits of their combined industry.

There is not the slightest doubt that considerable irritation exists, and that difficulties are continually being produced by the position which Labour occupies to-day as solely that of wage-drawer. Employers who object to take their employees into co-partnership, and who fail to see that one co-partner is better than two wage-drawers, must never overlook the fact that it is the prospect of reaping a harvest of profits and the consciousness of their ability, by effort, to increase profits and their own share therein, that afford the most powerful stimulus to employers in maintaining and sustaining their efforts throughout the whole active period of their business 
life. There is only one other stimulus a business man has, and that is the joy of such work, the pleasure of cultivating the development and growth of a successful business.

The employee, on the other hand, is cut out not only from sharing profits, but largely from this further joy that comes to the employer. How many employers realise the benumbing, depressing, devitalising effects of the present wages system of remuneration for labour, and the "whole life" sentence of working for wages without direct interest in profits earned? Such "life sentence" would equally kill the enthusiasm and energy of the most high-minded and conscientious employer.

It is not only that the wage system, by precluding from a share of the fruits of industry, is manifestly unfair, but it is also apparent even to the least thoughtful that the wages system dulls and deadens the keenness of even the best and most conscientious workman, and produces a mob of "ca' canny" shirkers and slackers. What inducement can the day-wage system give to, say, the bricklayer, to make a study of the laying of bricks in as few movements and with as great exactitude as possible so as to train himself to lay more and more bricks and lay them better and better each succeeding year, whilst at the same time he knows, by bitter past experience, that under the wages system his remuneration is fixed without any regard to his efficiency. Piecework for bricklayers, and in all trades to which piecework is applicable, is almost dead and wholly damned. This has been caused by the fact that some employers, after having ascertained the speed limits of the efficient workmen, have cut down the piece rates proportionately. 'This cutting down of piecework rates is exactly contrary to the system on which the employer himself has attained to 
his efficiency and maintained the stimulus of his interest in his work. The employer whose balance-sheet shows one year a certain margin of profit is stimulated, on sound right lines, to produce each succeeding year a still larger balance of profits. He studies the source from which his profits spring, and discovers that he makes the most profit where he renders the most efficient service, that economy of production, quality of goods, and regularity of service to the public are the factors that tend to increase his profits. But this lesson is exactly the opposite of the lesson presented to the bricklayer or piecework employee who finds that improved service and greater efficiency merely result in remuneration rates being eut down.

In my opinion, if this resulting cutting down of profits were the only lesson taught to the enployer by his own bitter experience, then his interests in the direction of increased output and efficiency would be similarly dulled and deadened. It is because the employer is taught the lesson that increased output increases the profit shown in his balance-shcet that he learns the lesson of efficiency.

In business, as in all affairs of life, we can only get out of business what we put into it. It is only when we give our best efforts, our trained intelligenee and our whole-hearted service to the public, that our balancesheets can be made permanently satisfactory, and our business be founded on solid, bedrock foundations. If the employee were to be treated exactly as the employer is treated, then he would learn the same lesson, and would also learn that the policy of restriction of output which would lead the employer to the Bankruptcy Court must also lead the employee to unemployment and starvation. 
Every man, be he employer or employee, is a purchaser as well as a consumer. We must, therefore, to achieve real and not imaginary better conditions of life, have, in addition to the wages system, a system of co-partnership which entitles the workman to his proper proportion, fairly and justly arrived at, of the profits of the undertaking. Business and productive enterprise are not a game of horsebetting and "spotting the winner," or a game of cards and of luck. We none of us can get something for nothing, whether we are employer or employee, Capital or Labour.

It has been stated in some American papers that the mere fact that Trade Union officials disapprove of co-partnership is of itself the best recommendation for the system. In my opinion this opposition, when and where it exists, is the result of confusion in thought on co-partnership, and often of the presentation of copartnership as a system of charity or benevolence. In my contact with trade unionists and Trade Union officials I have found them whole-heartedly desirous of promoting, according to their knowledge, the best interests of the workmen. 'There may be 'Trade Union officials who are opposed to co-partnership from improper reasons, just as there are undoubtedly some employers who still cling to the idea that their employees are dependents who ought to be satisfied, however prosperous the state of the business. with any crumbs in the form of moderate increases in wages that the employers may deign to throw them. But whenever and wherever there are Trade Union officials and Trade Union workmen who do take the view that their best and permanent policy must be one of antagonism to the employer, and that the only true relation between Capital and Labour is a continuance of the spirit of distrust and suspicion and of 
perpetual working at cross-purposes with each other, then to make to such the offer of co-partnership would be about as sensible as it would have been for one of the Early Christians, thrown to the lions in the Colosseum at Rome, to have attempted to make friends with the beast by the offer of the half share of his dinner. T'he lion would not be palliated by the half share of the dinner, because it would be his intention to devour both the dinner and the Early Christian too-a policy that might be natural to beasts of prey that are hunted down and exterminated, but for intelligent human beings about as short-sighted as that of killing the goose that lays the golden egg, and quite as effectual in destroying all hope for future gains!

But those imbued with the true spirit of co-partnership can brush both the unreasonable employer and the shortsighted employee on one side, and can attempt to make a combination by means of co-partnership between employer and employee, Capital and Labour. This, to be a square deal, must include the recognition of the fact that no one desires a lazy, indolent man as partner, whether he be employer or employee, that both must meet as colleagues doing their duty, whatever department of the world's work they are engaged in, and that both can agree on a fair division according to the ability of each, and according to the total profit earned-which total profit earned must necessarily vary, like the harvest, from causes beyond the power of the sower and reaper, being the effect of conditions of rain and sunshine, over which neither have any control. Profits will vary, but a fair division of the total profits earned can be made, and is always possible; but you will never get the willing consent of the actire, energetic worker, be he employer or employee, to share the profits produced by his industry 
with a lazy slouch and loafer, be he employer or employee, who has been an actual retarder of profit-earning and a waster of both time and money that ought to have benefited each and all.

Mr Theodore 'Taylor, M.P. - than whom I know of no one who has done more for the co-partnership movement-stated, in February of last year, that in his experience of his own staff, the weavers who produced the most work in quantity usually did the best work in quality, and whilst earning most wages for themselves, under piece-work, also benefited every other worker in the factory, thus proving that the true science of moneymaking, as of life and of all business, is the science of whole-hearted service.

With the advent of co-partnership will come improved conditions of living, not only for the employee but also for the employer. The employer will be greatly relieved from the necessity of bearing entirely on his own shoulders the load of gnawing care and anxiety entailed by his business. He will be able to get more out of life than the merely petty, miserable, round of his money-making office and workshop. $\mathrm{He}$ will have the support and whole-hearted service of all his co-partners.

'The employee co-partner will get out of a system of co-partnership the only possible basis of improving his condition of living. Alone the wages system defeats its own ends. Every increase of wages unaccompanied by increased output results in an increased cost of manufacture, which increase is charged against the cost of the article produced. 'This, in turn, raises the cost to the wholesale and retail distributor, with the result that increases in wages are entirely cancelled by the increased cost of living. Not so under the stimulating influence of the true spirit of co-partnership. The very essence 
of co-partnership is to reduce the cost of production by increased output resulting from enlightened selfinterest and greater efficiency. Profits are not added to the cost of production. They are the remainder after realisation of the product, and therefore a division of profits brings income to the co-partner that is not "watered" by corresponding increases in the cost of living. Therefore, co-partnership would produce a real betterment.

Our industries and commerce are all capable of indefinite expansion. There are hundreds of millions of acres of uncultivated land within the British Empire awaiting development. The development of these hundreds of millions of acres, and the introduction into our factories of labour-saving machinery, will become the basis of profit-earning, whilst reducing the cost of production. By means of these and the true spirit of co-partnership, not only will more articles be produced, better in quality and cheaper, but increases in wages will become possible without corresponding increases in the cost of production. Thus, by means of the profits divided amongst co-partners, a higher level of living will be placed within the reach of every employee. It will not merely be a case of more income to pay for the old style of living, but a case of better and more comfortable life, better housing, better education, better clothing, better food, with more leisure and greater opportunities for relief from toil, placed within the reach of the employee. All this can be realised by wholehearted efficiency, stimulated by the true spirit of co-partnership and by the willing adoption of laboursaving machinery and devices. Without the operation of co-partnership and of labour-saving devices and machinery the cost of higher living would continue to 
be out of the reach of the worker; but by means of these, then higher education, shorter hours, improved quality and higher output can be attained with lower cost to the consumer. We must remember that the overwhelming majority of the consumers are employees.

We have in the United States a splendid objectlesson as to what can be done, notwithstanding the existence there of the world's highest rate of wages, by means of labour-saving machinery, to obtain the world's lowest cost of production. We have in China and India an object-lesson which shows that, notwithstanding the world's lowest rate of wages being in existence in these countries, the cost of production in then is higher than it is in the United States. As proving what intensive production can accomplish in the British Empire, we are to-day, with five million men withdrawn from industries for service with the Navy and Army, able to produce, aided by women-labour, enormous quantities of munitions, and maintain a generous output of manufactures for home and export trade.

This great productive capacity has been made possible only by appealing to the highest patriotic motives of the workers, and proves clearly that we have only to touch the right chord in the human heart to meet with whole-hearted response.

We are a business nation, and it is not unreasonable that the employees should take the point of view that, under the former pre-war conditions it was not any advantage to them to put forth their highest productive abilities; and we may reasonably expect that, under the influence of the "square deal," ensuring a fair division of profits, the result will equally be whole-hearted service; and that, when assured thereby of greater comfort, better living conditions and more complete happiness, 
the employees will respond to such new peace conditions just as certainly as they have responded to the new war conditions. Once he is convinced of his power to raise himself and his wife and family in comfort and happiness, the British employee will help to build the British Empire on the solid basis of industrial efficiency.

There is all the difference in the world between selfishness and self-interest. The worst motive a human being can be actuated by, even from his own mere selfish point of view, is selfishness, whilst one of the highest motives, and certainly a heaven-inspired motive, is that of enlightened self-interest. Under the elevating influence of enlightened self-interest, Capital and Labour, employer and employee, can be combined as co-partners to make efficiency and higher production a steppingstone to greater comfort and happiness. The employee must have placed within his reach, as the direct result of greater effort and efficiency of production, the power to secure a ligher standard of living, with greater comfort and happiness for himself and his wife, and better conditions of life and education for their children.

All employers have enormous powers under the present industrial system, and have consequently the correspondingly heary responsibilities of duty, and each employer, as a necessary basis for efficiency in the employees, must see to the fulfilment of his own duties and responsibilities to those employees.

'The present-day employer is too hide-bound, and wishes to apply too rigidly theories that are daily becoming more and more obsolete. The employee, just awakening to the brilliant prospects before him, and feeling the warmth of the rising sun of social advancement just showing on his horizon, is apt to apply, 
without sufficient thought, theories that are untried and that are often unsound.

The employer cannot avoid his heavy burden of responsibility, nor can he secure the full advantage of his organising ability, apart from admission of his employees into co-partnership. It is equally true that the employee cannot achieve higher conditions of life apart from increased output and reduced cost of production. It would just be as logical for the employee to attempt to pull himself up by his bootstraps as for him to attempt to better his conditions in life by any other means than those here indicated.

There never was a period in our history when enlightened methods were more necessary to the nation's existence. We shall, with all our Allies, have to carry a heavy load of debt when this war is over. Neutral uations will not have this load of debt to carry, and will not have suffered the loss of their best manhood. They will be ready prepared, as soon as peace is signed, to enter the struggle with us for commercial supremacy. In addition to bearing the burden of this heavy debt and of increased taxation, ourselves and our Allies will, when peace is signed, have to face the problem of the restoration of pre-war conditions, and to make good destroyed cities and villages and all the wastage caused by the war, in order to restore productive enterprises to their accustomed channels.

Our shipowners and manufacturers will, when peace is signed, find themselves at a disadvantage from the effects of the deadly blow dealt them by the Excess Profits Tax, than which there never was a tax more unjust and unequal in its incidence. The policy of the Government ought to be to encourage small industries, to stimulate the young man entering into business, and 
to make conditions favourable to the introduction of the latest machinery, and to the prompt scrapping of old, obsolete machinery. 'The Excess Profits Tax presses lightly on the old established business and the old manit presses with deadly, crushing weight on the young progressive business and on the young man.

Habits of thrift will have to be encouraged, for, after all, it is only on the basis of thrift that any nation can be made permanently successful and able to hold its own persistently in the struggle with other nations for commercial position.

As bearing on thrift, it appears to me that the present system of payment of wages to the workmen by cash enclosed in an envelope, and handed out at the pay office on pay day, is the most unthrifty way of paying wages that could be devised, as well as a great waste of time. The day must come when wages of the wage-earner will be paid, as are most salaries, by a credit to his own banking account at a bank of his own selection, most probably the bank nearest his own home. The effect of this would be, that he would draw from the bank from time to time what was required for living expenses, and would leave in the bank whatever he could save from week to week. There is all the difference in the world between carrying cash loose in the pocket and attempts to save some of that loose cash, and the opposite course of having one's private account at some bank from which one must go to the trouble of drawing out the money required to be spent. It is much easier to be thrifty under the latter condition, for every tendency under such condition is in favour of thrift.

In conclusion, let us never forget that business is founded on the principle that by a peaceful pursuit of productive occupations all may gain and none need lose, 
all may advance and none need be forced by circumstances to retire. We can all make money by each doing his or her share of the work and service to the world better and more effectively than by any other method. None of us can permanently make money out of the losses of others. And this is specially true in relation to employer and employee, Capital and Labour. 



\section{IV}

\section{By ADELAIDE MARY ANDERSON, M.A.}

Wirhin the three years now elapsed of the "people's war for freedom, justice, and self-government among all the nations of the world," that began in August 1914, we have been watching in Great Britain the quickest of large expansions in the industrial position of women of which we have any historical record. On a lesser scale, at a far less rapid pace, there took place another famous expansion, during the revolutions and wars of the close of the eighteenth and beginning of the nineteenth century. That, however, which was not directly the outcome of war, but of inventions following the application of the power of the engine to industrial machinery particularly in the textile and allied trades, led, in the interests of rapid, capitalised production of wealth, first to the exploitation of child-labour, and then, while legislation for their protection arose, to extensive employment of women and girls. 'The change was substantially not a new introduction but a transference of women's labourwhich under all systems of industry had been largely utilised-from the domestic to the factory system of manufacture; it laid at the same time the foundations of what is now known as "dilution," and greatly extended the future possibilities of their employment. Essentially, 
that "Industrial Revolution" meant for the women a change from the domestic form of occupation to an increasing employment as independent wage-earners, with all the mingled social and economic good and evil involved in the passing from a traditional customary status to at least a nominal personal freedom of contract and power to control their own earnings. The evil, indeed, sometimes seemed to have the upper hand, for the spirit of feudalism and domestic serfdom passed to a great extent into the control of their lives by the new masters of industry.

The change we are witnessing now cannot be fully understood in all its possible consequences without some comprehension both of the industrial and social conditions under which women have laboured from 1844 to 1914, and of the great contrast between the proximate causes of the expansion of their employment now and in the early nineteenth century, respectively. It was in 1844, after long sufferings and even degradations that cannot be set out in this chapter, that their hours were first regulated by law in textile factories; and in the years just preceding 1914 that their long, apparent passivity under many repressions and economic insecurities was quickly turning to claims for a better life, to criticism of the limitations of the slowly-developed law relating to factories, and to fresh courage in voicing their needs to employers. ${ }^{1}$ This last change had followed, be it noted, some twenty years of increasing co-operation with the factory inspectors in setting the existing law in motion, as well as growing readiness for 'Trade Union organisation.

Turning to the contrast between the causes of our last "Industrial Revolution" and the present one, the driving power in the former was possession of new means,

${ }^{1}$ See Annual Report of the Chief Inspector of Factories, 1913, p. 70 . 
and the will to use them, for multiplying production of wealth for individuals, while statesmen and economic theory approved the aggregation of national wealth through amassing of individual fortunes. Now, in these latter days, war, on a greater scale than ever before, reveals the hidden foundations of many things, and from the outset it appeared that the industry of women could be even more important to the nation in war than in peace. The cause of the latter expansion and the call to it are wholly national, in complete contrast with the motive power in the former change.

Long before anyone realised the enormous need for output of ordnance, ammunition, aircraft, shipping, chemicals, and other "munitions of war," women were playing an indispensable part in equipping the army and navy in cloth, clothing, hosiery, bandoliers, light leather and metal articles, tents, surgical dressings, tinned rations, fruit and vegetable preserves, and miscellaneous articles. "No army," said the military correspondent of the Times in the winter of 1914-15, when the small British Army was expanding into millions, "was ever better fed, and the fresh supplies of clothing which have always been at hand when needed have enabled the troops to be refitted constantly and well." As a Factory Inspector said about the same time, "It is only by visiting the factories that one can realise the extent to which the equipment and comfort of the troops in the field depends upon the work of the women and girls at home, and the amount of overtime worked has only been possible without injurious effects because the workers have been so glad to help." 1 As another said, "The effect of the unheard-of demand was almost startling. The demand followed almost all at once upon trade stagnation, which seemed to threaten

${ }^{1}$ Annual Report of Chief Inspector of Factories, 1914, p. 40. 
annihilation.

Contracts of inconceivably large dimensions ... were required with such insistent haste that nearly every firm was at its wits' end to know how to carry out its undertaking." 1 "We never seems to get any rest, but if we did not do it nobody else could," said a woollen weaver in those early days of the war. Among the purchases during the war by the Army Contracts Department, says a White Paper issued 28th June 1917 , are 105 million yards of cloth, 115 million yards of flannel, 260 million tins of jam, 500 million preserved meat rations, 25 million smoke-helmets. ${ }^{2}$.

So far, it was chiefly a case of enormously increasing the share in manufacture by women, and of all these products at which for a century they had without serious question been employed. Even in the early developments of manufacture of aircraft, beginning before the war, simply an enlarged field was offered at first for women's traditional skill in weaving and needlecraft, although later their work there extended to other branches. At the outbreak of war, their own great industries in textile and clothing nianufacture absorbed probably $1,178,000$ out of the total of approximately 2,000,000 women and girls employed in the whole of the industries of Great Britain and Ireland. In the engineering and metal trades, except in the lighter branches, women played before 1914 a very subordinate part, owing chiefly to the demands made by these trades on great muscular strength and endurance, by heavy work, special skill, and extremes of heat and exposure. Further, in these fields lay a great stronghold of 'Trade Union organisation, naturally opposed to the introduction of nearly inarticulate subsidiary workers always peculiarly liable to exploitation in matters of wages. Moreover,

${ }^{1}$ Annual Riepoit of Chief Inspector of fractories, 1914, pp. 41-2.

2 Memorandum on War Office Contracts, Cd. 8447, p. 3. 
these metal trades, as well as chemical trades, were relatively in an earlier stage of mechanical and scientific development in Great Britain than the great industries which had hitherto largely claimed women workers. Explosives manufacture, indeed, with many light branches, in aid of mining and construction works as much as for munitions, had long drawn in girl labour, and here there were possibilities of rapid expansion when the labour of men and boys was indispensable elsewhere.

It was in an intermediary stage of the great struggle, before full realisation was attained of the need for a revolution in output of primary "munitions of war," that entirely new claims began for the services of women as substitutes for men. First arose perception of the need for them in general service of the community in transport, clerical and commercial work, distributive services. Then early in 1915 research began on the part of the Home Office and Board of 'Trade into the possibilities of release of more men for the army in manufacturing industries, first in the less essential industries, but also in industries essential for national needs, and those in which, by substitution of women, and men of non-military age, important export trade could be maintained. At the request of the Army Council, following the Treasury Agreements in the Spring of 1915, these departments instituted, through their superintending inspectors and divisional officers, a series of Trade Conferences of Employers and Employed, ${ }^{1}$ to consider what measures of reorganisation might be necessary to set free as many men as possible. Although many difficulties appeared, yet collective agreements were harmoniously secured in a number of trades, providing for temporary suspension during the war of recognised Trade

${ }^{1}$ See Annual Report of Chief Inspector of Factories, 1915, p. 4. 
Union rules and customs, and for suitable and safe conditions of work and for rates of wages for the women to be introduced, with promise of a full restitution of pre-war rules and customs when peace returned. 'The negotiations for the agreements aimed both at prevention of dislocations at a critical time for national industries and at maintenance of the standard of life of industrial workers in the future.

Trades included were cotton, woollen and worsted textiles, bleaching and dyeing, hosiery, china and earthenware, coarse ware and bricks, woodworking, boot and shoe making, glove - making, baking, brushmaking, electroplate, and printing industries. In many other industries, where absence of organisation made collective agreements impracticable, substitution was carried out under the guidance of the Factory Department, e.g. in the paper and indiarubber, soap and candle, oil and seed crushing, tanning and currying, sugar-refining, chemical, cement, and other industries. ${ }^{1}$ Emergency orders were made by the Home Office, through powers held under the Factory Act 1901 and Defence of the Realm Regulations, allowing, conditionally on provision of safeguards for the welfare of women and young workers, relaxation of the law with regard to overtime spells of work, night work, Sunday and holiday labour. These orders were at first necessarily special for individual factories, and a wide variation had to be experimentally allowed in legal hours and times of work, to meet sudden pressure or local difficulties. The tendency soon grew, however, to standardise these exceptional hours, and, as far as possible, general limits for particular industries, or groups of them (as in the case of munitions), were laid down in alternative

${ }^{1}$ See Pamphlets on Substitution issued by the Home Office and Board of Trade. 
schemes set out in General Orders, in which all firms in the industry could find an arrangement suited to their needs. The long day followed by overtime soon gave place to the shift system-sometimes the three eight-hours shifts recommended by the Inspectors, but more frequently by the two twelve-hours shifts in the twenty-four, which for various reasons were found easier to organise in the larger factories, particularly when more and more men were withdrawn from industry. Some of the Special Orders authorised Sunday labour, but it was soon demonstrated that a weekly day of rest was essential for maintenance of the well-being and efficiency of the worker, and Sunday work has been more and more limited and controlled.

Although in the rush, and some inevitable confusion, following on these great changes-industrial, legal, and administrative-excessive and irregular hours were often worked, Factory Inspectors' returns showed that they were met with the courage and endurance that those who knew their past life would expect, by both women and girls. Records of complaints decreased, and fell far below those of easier peace times. The motive of work for country and friends, and a wide and profound belief that we had a "quarrel just," undoubtedly led in producing this high spirit. Yet, heightened pride in enhanced valuation of their services, new and varied interest in work, access to opportunities for training, as well as, in certain cases, receipt of men's pay for men's work, also strengthened their powers of body and mind, and gave point to the utterance of a managing foreman to the writer: "There is more in this than people think; women have been too much kept back." One is strongly reminded of the saying of Galton that energy, the capacity for labour, is an attribute of the higher races; and women of the United 
Kingdom have proved that they have held this endowment in trust.

Inquiry directed by the Departments showed that most of the training given in non-munition industries was organised within the factories. 'The leather and boot trades, however, were specially aided by technical training in existing colleges or newly organised classes.

Close on the intermediary stage came, with the munitions of war crisis of 1915 to 1916 , a third stage in the demands of the war on women. The call to them to enrol for dilution of labour on munition work, especially in engineering and metal trades, on a great scale, accompanied the sudden realisation of the necessity for extraordinary development of the technique and machinery of these industries to meet and overcome the national peril. From the beginning, preparation was made not only for introduction of women by way of dilution, but also, through training, for specialised skill-although, on the latter, ideas expanded with the response from the women to the new enthusiasm applicd by officers of the Ministry of Munitions to their technical training. 'The widely varied range in their new work is in part familiarised to the public by the many beautiful illustrations given, in picture palaces as well as by Government prints and exhibitions. ${ }^{1}$ It would be impossible here to convey the endless variety or the nature of the operations and occupations on which women are employed, not only in all metal industries, including even foundries, blastfurnaces, and forges, as well as engineering, but also in ship-building, chemical and gas works, and construction work, as well as explosives and aircraft. It suffices for the present purposes to point out that it is the public

${ }^{1}$ See, inter alia, Women's War Work, issued by the War Office, Chiswick Press. 
official testimony of the Ministry of Munitions, that in munition work, not merely have they been able, by the addition of women's labour to that of men and boys, to carry through the quick specialisation known as dilution, and to gain an immense additional power in repetitive production, but that they have also found, in processes requiring manual dexterity and delicacy of touch, some which women can do better than men, and some, even, which women only can do.

The White Paper alluded to above gives the most recent evidence of women's extending aid even in personal equipment of the army, apart from munitions. "The present demands (June 1917) for razors average 90,000 per week. About half of these, except for the man who works the power hammer or the drop stamp, are never touched by anyone but wonen; women grinding them, honing and stropping them. In 1914 Sheffield could not produce 30,000 razors a week for army needs; now, in addition to the 90,000 required by the army, the navy and India Office are supplied, while the nucleus of an export trade is kept alive." 1 And yet, very far greater are the expansions of output in munitions-e.g. high explosives twenty-eight times as great in March 1917 and machine guns twenty times as great as two years ago; aeroplanes twice as great in May 1917 as in December 1916. ${ }^{2}$ Truly it is now, as in 1914, "the rapid pace that strikes the mind on looking back, no less in the industrial than in the military and social worlds." 3 While women have been called more and more into direct manufacture of material of war,

1 Memorandum on War Office Contracts, Cd. 8447, p. 10.

2 Parliamentary Debates, 28th June 1917-Dr Addison's statement.

${ }^{3}$ Quoted in Annual Report of Chief Inspector of Factories, 1914, p. 35. 
more and more have the tentacles of this war wound their way into the centre of all manner of industries, bringing about a great extension of the meaning of "munitions," and consequently of control by the State of the methods and conditions of output, as well as of the relative numbers, sex, and classification of persons to be employed therein.

Strangest of all, may we not see it in the future to be, that war should have gone so far as it has towards establishing a legal claim for women to a living wage, in a great organised men's industry, and their rapid assistance by the resources of the whole community for becoming competent workers. However far the rising tide of war or post-war prices may overtake the considerable advance that is yielded by piece-rates, overtime rates, and premium bonus time allowance based on the Ministry of Munitions' circulars and arbitrations of wages tribunals on the pre-war wages for women, ${ }^{1}$ these are socially fruitful new ideas that cannot be lost. Especially significant, too, is the recognition gained for women of a claim for time lost in waiting for work.

Probably equally outstanding in future social importance is the experience gained of the great potentialities of assisted mobility of women's labour through the migrations organised by the Employment Exchanges all over the kingdom. This outweighs the temporary effect of a measure of compulsion on them to stay in a munition factory after once entering, which limited, for the time being, ordinary freedom of contract, and in

${ }^{1}$ Dr Addison gave the minimum in 1917 as 22s. time-rate for adult women and the average as $25 \mathrm{~s}$. If a pre-war average be taken on official returns, the wage for women over eighteen years of age in factory industries, exclusive of cotton textiles, was 12s. 11d. before the war, including cotton textiles (the premier women's trade) it was $14 \mathrm{~s} .2 \mathrm{~d}$. 
some degree assimilated the position of the munition worker to that of the soldier.

'The net increase in numbers of women actually employed is probably far less, whether in magnitude or significance, than other changes so briefly touched on above. The total increase given for all occupationsindustries, agriculture, commerce, transport, hotels, civil service, etc., as well as industries-was in the Labour Gazette for April 1917, 1,072,000, and within these, for industries and for persons employed in national factories, arsenals, and dockyards, 570,000, of whom 515,000 were in direct replacement of men. It is the movement and migration of women that is remarkable rather than the increase so far attained in their numbers industrially employed. There was certainly, during the first two years of war, a great turnover of women from luxury and unessential occupations to industries essential for the nation, as well as a gradual reabsorption of those thrown into grave unemployment at the outbreak of war. Although it has been stated that over 900,000 women and girls actually work in factories producing munitions of war, they are composed less of new additions to industrial life than of transferred workers from the most diverse occupations from far less well paid employment. Women's labour migrated, and, placed in employment through the exchanges, rose from 32,000 in 1914 to 160,000 in 1916, and is further rising in the early months of 1917 . The migration varied from a systematic redistribution of unemployed in neighbouring districtse.g. carpet weavers, dressmakers, domestic servants, to munitions or rubber work within the Midlands-to an importation from Aberdeen and Penzance to a West Midlands munition centre, ${ }^{1}$ where, indeed, so many have

1 See Board of Trade Labour Gazette, March 1917, pp. 92-3. 
been brought also from every part of the kingdom-Isle of Man, Wales, Ireland, and the Channel Islands-that the workers speak of themselves as belonging to "different nations." At the same time, though in the main the transferences have been of regular industrial workers, the importation of non-industrial elements has been large enough and sufficiently representative of different classes of the community to have an influence much greater than the numbers might suggest. The newly achieved mobility and mingling of all classes of womanhood in the workshop, may eventually prove, together with the national call that has brought them there, factors of immense consequence in the economic and social life of the future. Further extension and strengthening of these factors may be expected from the industrial war service of women of the Women's Auxiliary Army Corps in base workshops in France, at present in its earliest stages.

Another change of great significance, for after-war readjustments in industry, is the increasing number of women employed as substitutes for men, an increase more rapid than that in the total number of women employed. "The actual increase in the number of women engaged in the various occupations," says the Labour Gazette," "is no guide to the number of women engaged who are being employed to replace men. . . . 'This increase in the extent of substitution is found even in industries which are employing fewer women than they were three months ago. In the textile trades the number of women stated to be replacing men has increased by 8000 since October 1916; and in the clothing trades by 3000 ; and in the food trades by $6000 \ldots$ there is less disproportion between the rate of increase in the numbers 1 See Board of Trade Labour Gazette, April 1917, p. 126. 
of women employed and the number of women acting as substitutes in commerce than in industry, which is doubtless due to the fact that there is more scope for reorganisation in industrial than in commercial occupations." Adaptations of Factory Act requirements by the Home Office, both in the way of relaxation and of protective regulations, as well as alteration of machines, tools, and appliances in the shops, have been factors in facilitating the employment of women in various industries, non-munitions as well as munitions, that have played an essential part. Undoubtedly far more extensive than any form of direct substitution are the arrangements whereby groups of women, under a skilled supervisor, do work previously done only by skilled workers; or individuals are employed on semi-skilled repetition work by use of automatic machines. Both developments, however, while releasing new forces for revival of industry and increasing possibilities of prosperity and material welfare of the nation, have made manifest the cultivatable quality of the human agent in industry, and the past loss in too narrow a separation of the sexes. They have also shown something of the potential interchangeability and yet essential complementariness of men and women in industrial as in social life. Surveys, made by the departments concerned, of the whole field of these new experiments in employment of women, showing its nature, extent, results, changes in organisation necessary, and suitability for normal times, will be available, to guide steady progress on a groundwork of knowledge in the future.

The motives drawing them to the work in munitions and as substitutes for men being strong, the supply of women forthcoming to meet all these new necessary demands has, so far, over the whole field, practically 
been unlimited, since the early difficulties in the way of migration were met. Shortage, where it has appeared, has been in their own (and lower paid) industries. The direct detailed State encouragement of substitution, and pledge of ultimate restoration of 'Trade Union safeguards against lowering of the standard of life, have opened the way for them to many processes and shops which would otherwise have remained closed. It is evident that many new experiments on similar lines yet remain to be made, especially in the lighter skilled trades, ${ }^{1}$ and much more may still be learned from them, while women go forward with widened outlook, and new hope on the breaking down of artificial barriers against their initiative and skilled service in national industry.

It is not too soon, however, to take thought for certain social as well as economic factors in the situation, bearing in mind that we are still suffering industrial and national ills-in spite of the make-weight of Factory Acts and other social legislation-from the pressure of forces let loose at the last Industrial Revolution, that might have been averted by full recognition of the labourer as a person and citizen rather than as a "hand" and a wealth-producer. The mere transference of the centre of gravity from individual to national production will avail nothing to prevent yet worse ills if there be not also a change of heart and mind as to the whole meaning and purpose of production in industry. Many would be ready to see the social risks inherent in a widely extended and intensified employment of women in all great industries. More would be ready to recognise

${ }^{1}$ Such as scientific instrument and optical glass work, where the field for intelligent trained women is possibly greater than is yet realised. 
the potential loss in turning all our patriotic women munitioners into a new large industrial proletariat in men's trades, while also retaining our skilled women textile workers, tailoresses, food preservers, ceramic workers, laundresses, and domestic workers. It is possibly not quite so clear that if the aim of industry be merely material production of wealth and things unrelated to spiritual values, the risks may be even greater in producing for the State rather than for a fellow-creature. For in that case not certain individuals or groups only, but the nation itself, would be pledged to the materialistic aim and its issues.

The dangers inherent in great and sudden changes of economic and social relationships are clearly to be seen in the breaking away that. has occurred from traditional rules and customs, the mingling of all industrial types with non-industrial in-comers, the breaking up of homes, the rapid crowding into already crowded industrial cities, and building up in a few months of whole new townships. Invaluable as has been the controlling effect of the women's own heart-felt response to the need of their service, they had neither the special experience nor the political power requisite for organising their own safeguards. These things were relatively quickly seen by the Government when the call had to be made by the nation on a great scale to the natural home-makers of the people at a time when so large a proportion of the best manhood had been withdrawn from citizen life. Inter-Departmental Committees were set up to inquire and advise both local and central authorities, and to act, and to co-ordinate the work of available voluntary societies in these matters of citizen welfare. For safeguards inside the factories, the great departments concerned strengthened their legal and 
administrative powers, ${ }^{1}$ developing new conceptions and methods of handling problems of health and welfare. The Health of Munition Workers Committee, the Board of Control (Liquor 'Traffic) Canteen Committee, and the Central and Local Advisory Committees on Women's War Employment (Industrial) became important organs for the State in surveying the field of necessary action leading to adaptation or use of existing machinery, and advising in the setting up of new safeguards. ${ }^{2}$

Out of the work of the Local Advisory Committees, in their sub-committees on outside welfare, came one of the most promising signs of a new socialised estimate of the function of labour, and of recognition of the national interest in its conditions. On their own initiative a group of Yorkshire Local Advisory Committees have entered, in practical study of welfare problems of housing, transit to and from work, care of sick and convalescent workers, use of leisure and recrcation, into inter-civic discussions. They have met in conferences, at which they invited the attendance of leading officers of the Central Departments, who are concerned both with intramural factory conditions and with the outside social conditions of the factory - worker in great industrial centres. The setting up by the Archbishops of a committce, in consultation with the Bishops, to make provision for meeting the spiritual needs, especially of women munitioners, in new munition centres, by building additional chapels and providing chaplains, organising clubs and care of solitary workers in lodgings, and helping

1 See Munitions of War Amendment Act, 1916, especially Section 6 ; the Police, Factories, etc. (Miscellaneous Provisions) Act, 1916 ; the Billeting of Civilians Act, 1917.

2 See Memoranda of the IIealth of Munition Workers Committee, especially Nos. 2, 3, 4, and 17 . 
workers to organise their means of recreation, is another sign of the national awakening to the purposes and needs of Labour. It seems as though the very rapidity of consumption of the products of Labour has aroused a new consciousness of the truth that men and women labouring are greater themselves than anything they can produce in the way of material wealth, even when used for national defence.

The setting up by the Ministry of Munitions of a Welfare Department in 1916, with officers for detailed care of the health and well-being of workers on whom output depended in the munition factories, followed the past example of leading private employers in going beyond the general requirement of the essential groundwork of health and safety in factory law. A few months later the Home Office was enabled to carry that factory law itself a considerable step onward. By the Act of 1916, power was taken to require, by order in any factory or group of factories, provision to be made for securing the welfare of workers in matters of mess-roons, drinking water, washing conveniences, protective clothing, cloakrooms, seats, supervision, and to extend that list and arrange in certain cases for the co-operation of the workers themselves in management of these things. In some factories, before the Act is directly enforced, committees representative of workers, women as well as men, are already in existence for certain purposes of welfare.

The abnormal conditions of the time have led to an increase in scientific study, on both governmental and private initiative, of the conditions needed for efficient work and prevention of overstrain and fatigue. A new stage is opening for national handling of the problems of health in industry, and it starts with the great advan- 
tage secured by the long and solid work, medical and administrative, carried out in the regulation of "dangerous and injurious" trades, from 1891 to 1914, under the Factory Acts. The best hours and other conditions of hygiene and safety have yet to be scientifically worked out, in the light of human ideals, for individual types of industry and occupations.

The share to be taken by women themselves in the inevitably increased future responsibility, economic and political, of labour for its conditions has to be determined. It is bound to be large, however politically defined. 'The reconstruction necessary is largely social, and the common weal calls for a liberal measure of the socially constructive point of view of womanhood in government and industry to balance the pioneering spirit of scientific research and application of inventions to production of wealth, hitherto more common to manhood. Men have, by labour-saving and weight-lifting appliances and machinery, enabled women, without their help, to carry out every process in the making of large shells (even up to $3 \mathrm{cwt}$. in the rough, and 2 cwt. finished), except tool setting and adjusting machines. What ultimate gain will there be in these and other new productive powers for humanity, if women are not called in consultation as to the ends for which they are used and the conditions under which human agents exercise them? 'The part they have played during the war itself bids women rise generally from the passive, subordinate position hitherto mainly held in industry, and consciously take their share in control, as fellow-producers with men, with their other point of view, now of supreme importance to the life of each nation. Although the first claim for political emancipation of women began-in England-in the leisured classes, it first became a strong appeal when industrial women began to see and express 
their need for legislation shaped to their own perceptions, experiences, and ideals, not only of their own but the nation's needs.

Men's inventions of the late eighteenth and early nineteenth centuries brought national wealth beyond the dreams of avarice, through enormously multiplied possibilities of production. They also brought new means of securing public health in treatment and prevention of disease. At the same time they drew the homes of the people away from the country to the town, made Great Britain in the main dependent on food grown outside the country, broke down the applicability of traditional domestic lore of women to the life of the people, and largely failed to secure socialisation of the means of housing, feeding and nurturing the race, particularly young and adolescent life. Probably, even with the right to dispose of their own earnings, British women were more dependent at the close of the nineteenth century for all they needed than they were under the domestic system. 'This, however, though true of Great Britain, has not been so in the younger dominions, Australia and New Zealand. In these new countries, free as they were from surviving conventions from a historic past and from accumulated wealth, where every woman's service had individual economic value, enfranchisement of women began in 1893 , and gradually spread to every part of Australia.

Not until women had wrestled for and won their claim to higher education did really good secondary education begin for girls in England, nor were schools of domestic economy nor women's settlements founded in the towns to redress some of the losses of the people. Not until appalling loss of life arose in the Crimean War did the science and art of nursing sick and wounded come to a sound basis, through the nation's appeal to the insight 
and organising genius of a woman. Even when women had won their way into medicine and surgery, organisation of infant welfare could not begin for lack of houses that could make healthy homes in which to bear and rear the majority, not to speak of the economic insecurity in the lives of the mothers. Even an adequate midwifery service for working women is still to organise, for the possibility rests on access to the national purse over which,women' have hitherto had no control. In these and kindred services for the homes of the people lies the groundwork of future reconstruetion of any healthy, sane, industrial, and national life. Whether women are to fill a permanently enlarged place in the industrial army, or have to meet such unemployment on the return of the army to industry, when peace comes, as they had to meet on the outbreak of war, every woman that can be spared will be needed to train and work and lead and organise, from the highest executive posts, through many grades, down to the subsidiary services, for the building up of the health, and social and spiritual eare, of the race. Here, with a rational application of the resources of eivilisation and the nation's capital for establishment of an adequate service of midwives, domestic helps, sanitary inspectors, health visitors, maternity and infant welfare centres, nursery schools, recreation sehools and playgrounds, invalid and communal kitehens, forewomen and supervisors in factories, cottage baths and laundries, club and care committees, organisers, probation officers, as well as policewomen and patrols, occupations and outlets of the amplest and most satisfying kind ean be opened for the women, if any, set free from industry. There may be room even for release of "woman-power" by simplification of the machinery of domestic life, certainly also for volunteer work of unemployed wealthy women. 
In any case, as regards the huudreds of thousands of women drawn into munition centres away from their previous surroundings and occupations to meet the needs of the nation, the nation itself has the responsibility of restoring them, not necessarily to a semblance of their old life, for that is probably impossible, but to an integral place in the National Economy. 



\section{V \\ By R. H. TAWNEY}

Whatever may be the military and diplomatic issue of the present conflict, one prediction may be made with confidence. It is that the social and political existence of the majority of Englishmen now living will be dominated by the forces which the war has liberated. Russia may be the only country to depose its old régime amid the rattle of machine-guns, because Russia was the only country where the political system was too brittle to change and too odious to endure. But the significance of moral and economic forces is not limited to the varying national forms in which they find their outward expression. If Russia is the only country where the war has meant an explosion, there is no country in which it has not closed an epoch; and the parliaments of England and France will be as powerless to revive the past as the Romanoffs were to maintain it. Nor, indeed, does it seem probable that the public will desire them to do so. It speaks of reconstruction. But by reconstruction it means not the resuscitation of the past, but reform. This is a war after which there will be no Restoration.

The England of 1920 will differ from that of 1914 , not merely because it has passed through a new Industrial Revolution, but because of a new quality in its moral and intellectual atmosphere. Partly as the culmination 
of movements which were going on in all European countries before 1914, partly as the result of the development of thought in the forcing-house of war, the world has been prepared, side by side with the practical innovations in its industrial organisation, for a revolution in the standards by which industry and social life are judged. Not merely the facts, but the minds which appraise them, have been profoundly modified, and the mere material readjustments in the technique of industry, which supply the text to discussions of reconstruction in the Press and on the platform, will in a few years, it may be anticipated, prove the least of the changes induced by the war. When peace returns, it will not be sufficient, therefore, merely to accept and legitimise the fait accompli. It will not be enough simply to acquiesce in those industrial changes which have been proved by experience to contribute to economic efficiency, and to introduce only such reforms as may be needed to regularise the situation, to smooth the transition to normal industry, or to buttress the weak spots in economic organisation which the war may have revealed. The publicists and politicians who think that the situation can be met by speeding up the economic machine, and by giving all classes some share in the increased output, while leaving their relative position and status unaltered, are building castles on land already cut off by the sea. Whaterer may be the merits of particular items in these programmes of national strength and industrial productivity, the programmes, as a whole, are tragically irrelevant. They are conceived upon the wrong plate. 'They are anachronisms.

They are conceived upon the wrong plane, because they omit the two rital elements in the situation. The first is the demand for radical social reconstruction, which was gathering weight long before the war made 
reconstruction an official policy. The second is the impetus to that demand given by the participation of almost the whole young manhood of Europe in a war during which an immense debate upon political principles has been tossed from corner to corner of Europe and America, over the heads of the combatants in the trenches. 'The war has not created the problems which reform must solve; it has only been the lightning which revealed them. When the nation found its soldiers and sailors threatened with a shortage of munitions and coal, because employers and employees could not agree as to the terms upon which their industries should be carried on, it was merely reaping in three years the harvest of seed sown for three generations. It was not overwhelmed by an unprecedented emergency. It was found out by its old sins. The question is not how to repair an industrial system dislocated by war. It is how to reform an industrial system which was felt to be incompatible with social freedom and justice in peace. We have to revise the work not of four years but of one hundred and fifty. The quarrel is not merely with the catastrophic changes of 1914 to 1919 , but with the economic order of the age which began with the spinning-jenny and ended with the great war of 1760 to 1914 . Social Reconstruction either means Social Revolution, or it means nothing.

'The problem is not new, and the principles by which it must be solved are not new. They are those which have been the daily bread of millions of men and women during the present tragedy, which have inspired the living, have comforted the bereaved, and have been hallowed by the dead. War is always shocking; but its remoter influence upon domestic policy and social organisation depends, to no small extent, upon the motives to which it has appealed for support. If domestic 
reaction was the natural consequence of the arrogant nationalism which was the note of Germany in 1870 , and of England in 1793, it is not too sanguine to believe that the liberal and humane ideals which, whatever may be true of governments, have been a spell to bind the common people of England and France to a hateful duty, will be a potent force for internal reform when they lay down their arms. Political thought and emotion cannot be shut up in compartments. Right as the basis of human association, freedom for weak as for strong, the moral law in public affairs-such ideas have a reference to social organisation as well as to international policy. Men who have read President Wilson's speeches in the intervals of a bombardment, or reflected upon Belgium before they went over the top, will be a little incredulous when they are told that the application of these principles to economic life and industrial organisation would involve readjustments too disturbing to be tolerated. When they can measure the full effect of the new industrial revolution, their incredulity will become vocal. They were told by philosophers and politicians that social change, if practicable, could only be gradual. Now they will discover that the economic mechanism, which seemed so ponderous and rigid, has been transformed in three years by a collective act of will, because there was a strong enough motive, which was not an economic motive, to transform it. They were told that the nation was too poor to offer the material conditions of a life of health and economic freedom to all its citizens. They will return to find it spending in a month more than the whole sum which it used to spend on education, public health, and housing in the course of a year, and in four months a sum equal to the total wage-bill of the comntry before the war. Unless 
the air of England is surprisingly different from that of France, they will ask whether this revelation of the possibilities of social transformation and of national resources does not contain lessons capable of application in time of peace. And at last, it may be suspected, they will insist upon an answer. Cette fois il faut en finir! "The blessings of Judah and Issachar," said a writer who endeavoured to explain, without much success, the political characteristics of the English people to a foreign king, " will never meet, that the same people or nation shall be a lion's whelp and an ass between burdens."

Such issues will confront all nations; but they should appeal, above all, to Englishmen. 'They should appeal to them because England was the power which led Europe into the labyrinth of modern industrialism, and the greatest contribution which it can make to human progress is to guide the world towards economic reconstruction, as two hundred and fifty years ago it guided it towards constitutional government. France is the hearth which guards the flame of social idealism for all mankind. But Vulcan has his function as well as Prometheus, and it is perhaps not mere national vanity to hold that England is specially qualified by its political experience for solving that part of the problem of the modern world which is concerned with the organisation of industry.

An industry, when all is said, is something in its essence quite simple. It is nothing nore mysterious than a body of men associated, in various degrees of competition and co-operation, to win their living by providing the community with some service which it requires. Organise it as you will, let it be a group of craftsmen labouring with hammer and chisel, or peasants ploughing their own fields, or armies of mechanics of a hundred 
different trades constructing ships which are miracles of complexity with machines which'are the climax of centuries of science and invention, its function is service, its method is association. Because service is its function, an industry as a whole has rights and duties towards the community, the abrogation of which involves privilege. Because its methorl is association, the different parties within it have rights and duties towards each other, and their neglect or perversion involves oppression. Now the subordination of strength and intelligence to the public service, and the organisation of civil association in accordance with justice and freedom, are tasks in which the larger England of history may not unreasonably claim to have achieved such success as falls to the lot of political humanity. Let her recognise the industrial problem for what it is, and she will solve it by her ancient methods worked out in her ancient spirit.

But she must recognise the nature of the problem. If the political genius of Englishmen is to be brought to bear upon industrial issues, industrial issues must be understood for what they are. They must cease to be sophisticated by being treated as exclusively or predominantly an economic issue, to be discussed in economic terms, and to be solved by economic considerations. Considerations are of economic efficiency is one element, but only one, and not the most important element, in questions which, so far as they are concerned with the individual, are human or spiritual, and, in so far as they are concerned with society, are political, in the larger sense of the word "Politics." There has been no more mischievous habit of thought than the smiling illusion which erected into a philosophy the conception that industry is a mechanism, moving by quasi-mechanical laws and adjusted by the play of non-moral forces, in which methods of organisation 
and social relationships are to be determined solely by considerations of economic convenience and productive efficiency. By erecting an artificial barrier between the economic life of society and its religion, its art, the moral traditions, and kindly feelings of human beings, that doctrine degrades the former and sterilises the latter. Pursued to its logical conclusion, the remorseless concentration on the organisation of economic power has fostered a kind of economic Machiavellism, a commercial MachtPolitik, which is the social counterpart of the temper against which the allies are fighting. Now that it menaces them in the guise of an armed nation, they can no longer be deceived, as England was deceived, by the imposing prizes which the Prussian spirit can offer to its devotees. Englishmen must repudiate an inhuman philosophy of economic life for the same reason as they resist an unmoral philosophy of politics. Superficially attractive by reason of the short cut which it seems to offer to material success, that glittering creed involves the subordination of all the finer elements in the human spirit to the worship of power. The intellect of England swallowed it for three generations. But then its intellect is not England's strong point. 'The popular instinct of the nation, not to mention the conscience of its prophets and the imagination of its poets, has always abhorred it. The perpetual malaise which its application to industry has caused in the body politic shows that it is uncongenial to our deeper traditions.

Since an industry, and the different parts of it, is at bottom nerely one kind of association, it is inevitable that those concerned in it should apply to it their political traditions, and judge it by its conformity with them. Of those political traditions the most powerful is that group of 
ideas which are summarised by the word "freedom." The idea of economic freedom offers a fascinating and neglected theme to the philosophical historian, and is the greatest single force in the social agitations of the present day. In countries where ideas are disentangled from their application, it is a banner under which mein march. In England, where remedies are stated and principles implied, the demand for economic liberty takes the form of lan aitack upon individual and concrete cconomic grrievances. These grievances are often summarised as poverty. But the summary is misleading. In so fär as poverty arises from the niggardliness of nature or the natural defects or human character, it is an evil, but it is not a grievance. What gives it its sting. what converts economic misery into a policical issue or philosophical problem, is the conviction that the poverty of the nodern world, since it is co-existent with riches, is unlike the natural poverty of the colonist, the fisherman, or the peasant, in being a social institution. 'Tyranny is none the less tyranny because it is unconscious, well-meaning, or even independent of the individual volition of those by whom it is exercised. Social poverty is merely one oulward expression, impressive because it appeals to the eye, of the power over the lives of mankind which modern industrialism confers upon those who direct industry and control the material equipment upon which both industry and social life depend. The fundamental grievance is not a mere deficiency of matcrial resources. Hunger and cold cause misery, but nen do not revolt against winter or agitate against the desert. 'I'he fundamental grievance is that the government of industry and the atilisation both of rapital and land are autocratic. Lrom men's exclusion from control over the organisation and apparatus of industry flow the particular gricrances which are the spur to their 
discontent. Their ability to add synthesis to analysis, and to see their evils in their causes, not merely in their effects, is the measure of their intelligence. It is no answer to the demand for economic freedom to point out that flesh is heir to evils which no social change can remedy. For the significance of liberty is that it supplies a touchstone by which men can discriminate between misery which is avoidable and misery which is not. It enables them to prevent that which can be prevented. Apart from the material evils which irresponsible power produces, it is alien to the political traditions of Englishmen that the livelihood of many should be dependent upon the arbitrary decision of a few, or that they should be governed in their daily lives by regulations in the making of which they have had no voice. In this matter the revolutionaries are the true conservatives. "Nolumus leges Angliæ nutari."

Stated in its most general form, therefore, the first problem of industrial organisation is to create in every industry which is not a matter of individual handicraft or shop-keeping a constitution securing its members an effective voice in its government. The conditions of economic liberty require, in fact, like the conditions of religious liberty, to be restated. For the last two centuries economic freedom has been interpreted to mean the right of each individual to be unfettered by authority in pursuing whatever occupation he pleases in the way which he may think best, just as religious freedom has meant merely absence of interference with the right of the individual to believe and worship as he may choose. This negative conception of liberty requires to be set in its place as one element in a more positive and constructive interpretation. Freedom, to be complete, must carry with it not merely the absence of repression but also the 
opportunity of self-organisation. It must confer the right to associate with others in building up a social organisation with a consciousness and corporate life of its own. Economic freedom must develop, in short, through the applications of representative institutions to industry. Except in the backwaters untouched, for good or evil, by the spirit of modern industrialism, it must rest on the recognition that all grades of workers in an industry and in every unit of it, from the organiser to the labourer, constitute a real community, and that in that community industrial sovereignty, subject (inevitable contradiction) to the larger sovereignty of the community, resides. Their freedom is simply their corporate power to control the conditions upon which their livelihood depends.

Their freedom must be corporate, because economic forces have decided that in all the staple industries production shall be corporate. In the shipbuilding industry, in transport, in the production of iron and steel, in the textile trades, in building, in general engineering, the firm which is the unit of the industry may include anything from a few hundred to several thousand workmen. It is a little society which is more populous than any village, sometimes more populous than many famous cities of the past. But, except for the Factory Acts and for the limited power of trade unionism, it is a society without a constitution and without a charter securing the rights of its members. Consider the position of a worker in such a firm. Politically a citizen, in industry he is neither a citizen nor a partner, but a hand. He is taken on when there is work; he is dismissed when there is not. If the trade is "organised" he may, through his Union, have a more or less effective voice in the settlement of wages and 
hours. If it is unorganised, the wages will tend to be the minimum needed to secure, under the pressure of competition, his services, and the hours the maximum which suit the convenience of the firm. As to the larger question of industrial policy, even as to details of workshop administration which affect him vitally, he has often no voice at all. In many industries methods of payment which he detests, like the premium bonus system, may be imposed upon him in spite of his protests. Piece rates may be arranged and rearranged without his being consulted and on no principle which he can understand, except that they will be reduced if he earns more than is thought to be "enough for a workman." He may have his livelihood abolished without compensation by the introduction of a new process or of machinery. He may suggest an improvement which would increase output, and either be snubbed for his pains or receive no adequate payment for it. He may be dismissed without appeal because he asks awkward questions, and he may, when dismissed, be prevented from getting employment in another shop by being blacklisted as an "agitator." Employment may be casual, as at most docks, because those who control it find it would be less convenient or more expensive to employ a regular staff, and as a result a whole district may be demoralised. 'The smaller the town-and it must be remembered that there are still many towns which are almost dependent on less than half a dozen great firms-the more obvious and absolute the influence upon the social life of the local employers. If one large business is badly managed, or goes on short time for eighteen months while paying at the same time (as in an instance in the writer's experience) a dividend of 20 per cent, a whole district may be temporarily half-starved, without possessing even the right 
to protest. What is this except "to live at the will of a lord"?

The alternative to industrial autocracy must be found in the development of associations through which the mass of the workers, in each industry as a whole, and in the units which compose it, can take part in its policy and organisation through representatives whom they choose. The difficulty is that the majority of industries are unorganised, and that in unorganised industries even the nucleus of such associations does not exist. In such trades reforms must begin at the bottom and be at first of humble dimensions. What is possible is to lay the foundations for organisation by establishing 'Trade Boards analogous to those set up under the Act of 1909. The necessity for fixing minimum rates for labour, with its implicit admission that it is the worker whose protection against downward pressure is needed, instead of capital being cheap and human services, as they should be, dear, is itself a proof that the present relationship of the different parties in industry is fundamentally wrong. But, as things are to-day, Trade Boards in the unorganised industries are essential, if only to prepare the way for a more comprehensive and spontaneous reorganisation. What is required is that there should be an increase in their number and a wide extension of their powers. Experience has shown that it is possible in the most intricate trades to fix and enforce minimum rates sccuring the worker a considerable increase in earnings. It has shown also that the mere establishment of Trade Boards has sufficed to give a great impetus to trade unionism in industries in which it was previously almost non-existent. Henceforward, therefore, they should no longer be regarded as an exceptional experiment to be applied only in 
exceptional cases, but as a normal part of the organisation of every industry in which standard rates are not already determined by an alert and effective trade unionism. They should be established forthwith in all trades in which there is any ccnsiderable section of men earning less than thirty shillings and of women earning less than twenty shillings a week. But their power should not be restricted to dealing with wages. Clearly they ought also to have legal authority to determine such matters as the maximum working day, and the conditions of learnership. But they should not be limited to dealing merely with such matters as might be set out in an amending Act of Parliament. Whatever may be the future government of industry, the first step is that the workers and employers in each trade should have full power to deal by collective regulations with all matters affecting it, and that the Trade Boards should be free, without recourse on each occasion to Parliament, to bring such additional matters within the scope of their deliberations and decisions as they may from time to time think expedient.

A wide extension of the system of Trade Boards is necessary as a bulwark behind which the most helpless classes of workers can mobilise their forces. But Trade Boards, after all, are in themselves a small matter. At best, they merely put the unorganised in the same position as the organised industries. 'They increase the workers' capacity for self-protection, but they accept his present status; and it is precisely the question of status which is at issue. If it is to bc altered, forces nust be set in motion in the organised industries which will transform their structure from within, which will carry it from one stage to another as each group of workers is ripe for a further advance, and which will 
not involve continual recourse to the intervention of the Central Government.

The starting-point for such a development must obviously be trade unionism. A beginning would be made if the principle of trade unionism were applied not merely, as at present, to questions of wages and hours, but to all questions of industrial policy and workshop organisation. Such a change involves a readjustment of the fluctuating boundary which at present separates "labour" from "management." The readjustment will often be difficult, but it is imperative. It is imperative not because management is unimportant, but because its importance is so crucial that it is vital that it should have behind it the confidence of all who are affected by it.

"What touches all should be approved by all." It need not be denied that an authority which is irresponsible is nevertheless often humane and far-sighted. But the claim of the employer, as it is sometimes interpreted, to "manage his business as he pleases," not only involves in effect a deniand that he should be free to impose upon men conditions of work against their will, but can also be used to undermine the control by trade unionism over wages and hours of labour in which most employers have at length, after a century of struggle, acquiesced. If a firm can introduce into the organisation of its works what changes it will, if it can alter piece rates as it pleases without having to justify the alteration to those affected by it, if it can rearrange processes and introduce new machinery without the workers being consulted, if it can dismiss whom it chooses without being obliged to give any account of its decision, it can, in effect, stultify trade unionism, even while according it a nominal recognition. 'Thus 
interpreted, freedom of management carries with it a control over the worker which is incompatible with civil liberty. It is incompatible, also, with economic efficiency. Indeed, the greatest single obstacle to the efficiency of industry is precisely the industrial autocracy which is supposed to-day to be the condition of attaining it, as 250 years ago men looked to absolutism as the crown of statecraft, and wondered at the tumultuous disorderliness of Englishmen. If men are treated as " hands," if they are told that "the best workman is the man who obeys orders and doesn't pretend to think," they may give their hands, but they will withhold their brains. The only guarantee of efficient work, whether on the part of a company in the trenches or of men in a workshop, is not the "discipline" of fear, but goodwill and mutual confidence.

If mutual confidence is to be the basis of industry, the organisation of industry must be such as to deserve it. It must be based on some kind of constitution. Precisely what form an industrial constitution should take is a question which will be answered differently in different industries. Nor will any one answer be final. The policy which has recently been popularised, as offering at least the basis of it, is the creation in the staple industries of permanent National Councils of employers and workers, together with the establishment of district and workshop committees in different districts and in individual workshops. Were this proposal carried out, the function of the National Councils would be, not merely to deal with disagreements, but to consider the general policy and needs of each industry as a whole, to represent them to the public, and to recommend to, or even to impose upon, recalcitrant minorities a line of action in accordance with them. 'The establishment of workshop committees 
would involve a surrender by employers of their claim to freedom of management, and would mean that questions of workshop discipline and organisation were settled in consultation with the workers in each shop. It would be for the National Councils, in the first place, to define the matters to be submitted to them. But among such matters would obviously be included methods of payment and the settlement of piecework prices, proposals to introduce machinery and to subdivide work differently, suggestions for workshop reorganisation, the appointment of foremen and overseers, and the dismissal of workers. The employer or manager would be required to state his case and to produce evidence in favour of it. The workers would not be restricted to the execution of orders coming from above, but would have a voice in the organisation and policy both of the workshop and of the industry as a whole.

To those accustomed to think of the present industrial order as the only natural or conceivable system, such a suggestion will seem a preposterous interference with the liberty of the employer. A more important criticism is that this tentative constitutionalism is a tacit admission of the need of more fundamental changes, which, nevertheless, it will do little to promote. It is to be welcomed as a recognition of the necessity of not merely improving the material conditions of the workers, but of altering the whole scheme of relationships upon which industry is based. But it is, at best, a transitional arrangement. The workshop committee, it may be suggested, will have too much power to be welcome to the employer, and too little to satisfy the workers. 'The employer', if he accepts it, will endeavour to circumscribe its sphere of operations for precisely the same reasons as have caused him to refuse to admit that questions of management are to be settled 
by collective bargaining with trade unionism. The workers will either find that the workshop committee is the mere illusory concession of a paper constitution, or they will renew the struggle for a larger share in the control of industry from the vantage-ground which such an organisation offers. It is, therefore, an illusion to suppose that the scheme which has been indicated offers any promise of diminished industrial friction. Like government which is representative without being responsible, it will strengthen the power of the workers for negative, without substantially increasing it for positive, purposes.

A negative voice in matters of workshop management is better than no voice at all. But there is no finality in the mere systematisation of the right of criticism, and its value consists in the opportunity which it offers for a more radical transformation of industrial relationships. 'That transformation must be found in substituting a relationship of co-ordinate service to the community, for the present subordination of the hired wage-earner to a master who employs him for purposes of profit. The work of the community must be done, and it ought to be done with the aid of the ever-changing improvements made possible by science and invention. If, therefore, the workers are to be able to veto the solution of industrial problems propounded by the employer, their status in industry must be such that they can offer an alternative solution themselves. If they are to resist effectively the types of organisation which menace them, they must not merely resist; they must take their part in discovering equally effective types of organisation which do not. If they are to exercise corporate freedom, they must be ready to undertake corporate responsibility. The truth is, that both the industrial tyranny denounced by the workers, and the 
industrial friction and inefficiency deplored by the public, are inseparable from the system under which the employer, instead of being with the workers a fellow-servant of the community, has a direct interest in extracting the maximum of profit from the latter and the maximum of work from the former. There is no alchemy by which mankind can extract from industry, any more than from the society of nations, a harmony which does not exist within it. Men may be willing to subordinate their interests to a cause or to the community, but they will not surrender those to each other; or, if they yield to force majeure, they will be continually in the temper for a revanche. While the profiteer and his workers live in a hell of embittered suspicion and call it peace, soldiers are able to face hunger and thirst, cold and heat and intolerable fatigue, because the loss of one is not the gain of another, and because the soul of an army, in spite of all the evils of military life, is comradeship in service. The service is exact because the leadership is disinterested. But if privates were employed for profit by officers, not a man would go over the top. As long as the organisation of industry is such that employers can snatch immediate advantages by squeezing the workers and the public, and that workmen see that the immediate advantages of industrial progress pass to their employers, so long will the latter be tyrannical and the former recalcitrant, and so long will the community suffer, and deserve to suffer, from the faults of both, which are also the faults of its own soul. From that conclusion there is no escape. As are the qualities which men covet, so are the defects which they must endure, for the defects are part of the qualities. If men are fascinated, as they well may be, by the brilliant prizes of plutocracy, they must bear the burden of its limitations. 
Poverty, economic oppression, and industrial strife are not superficial and transitory incidents of the present industrial order. They are an expression of its essential nature as fundamental as its mechanical perfection and imposing material prizes. Policies, like most modern "reforms," which accept the permanence of the relationship between hired wage-earner and capitalist employer, and seek merely to modify its effects, may disturb everything, but they will settle nothing. The practical course is not to attempt, by reshuffling the counters, to combine incompatibles; it is to transform the system.

The details of the transformation may be complex, but the principle is simple. It is that, instead of the workers being used by the owners of capital with the object of producing profits for its owners, capital should be used by the workers with the object of producing services for. the community. At present, the power of directing industry rests with the owners of capital and their agents. The measure of their success is personal gain; the method by which they attain it is the organisation of power, power which is mechanical and power which is human. Reformist movements, whether on the part of the workers or of the State, have acquiesced in that situation and conformed to the strategy which it imposes. Accepting as unalterable the mastery of Capital and the subordination of Labour, they have aimed at limiting the former, or at making the latter less intolerable, by fixing a minimum of wages, sanitation, and education, and a maximum of hours, beyond which the workers should not be driven. Such a policy is sound in what it attaclis and mischievous in what it accepts. For it assumes the relationship between capitalist employer and hired wage-worker, and that relationship itself is a vicious one. It is vicious, because it classifies human 
beings as a part, and a subordinate part, of the mechanism of production, instead of treating that mechanism merely as an auxiliary to the labour of human beings. As long as that postulate is maintained, it serves as a permanent force to override and pervert all individual reforms which, while leaving it undisturbed on its throne, seeks merely to curb its excesses by incidental and external intervention. What is required is not simply to limit the power of Capital to impose terms upon Labour, but to make the workers, not the capitalist, the centre of industrial authority, subject to such limitations upon their sovereignty as may be imposed in the interests of the community as a whole. It is to employ things in the service of persons, instead of employing persons in the service of things and of the owners of things. The character of modern reformist legislation is, indeed, an indication of the perversion of the relationships to which it is applied. If the human element occupied in industry the position of supremacy and direction which should belong to it, it might be necessary to fix a minimum wage for Capital. It would certainly not be necessary to fix a minimum wage for Labour. For Labour, in conjunction with the community, would determine what part of the product of industry it was worth while to pay in order that sufficient capital might be hired.

Such a reorganisation of industry would obviously involve fundamental changes in the relation of employer to worker, and of both to the owner of capital. "The employer would cease to be a capitalist or "master," and would become an organiser, who, as organiser, would take his proper place as one worker among others, and would be, with them, a fellow-servant of the community. 'The workman would cease to be a "hand," and would become a citizen of industry, who, like the organiser, 
had his own special work, and, like the organiser, had a voice in industrial policy and administration. 'The workers in each industry, including craftsmen, organisers, officials, and scientists, would be responsible to the community, through their representatives, for the service which the whole industry supplied.

The conditions of such a change are, on the one hand, a far higher degree of organisation than exists in most industries at the present day, and, on the other hand, the separation of management from ownership. 'The first can be developed only by the workers within each industry, and though the State can retard, it can do little to hasten, it. 'The second involves a change in administration which the State, if it pleases, can take the initiative in promoting. But it need not in itself involve a greater revolution, with regard to the legal ownership of land and capital, than occurred when the administration of the railways was three years ago placed in the hands of a council of railway managers acting under the direction of the Government. Administration would be vested in a joint board composed of representatives of the community, and of all grades of workers in the industry, acting through similarly constituted boards in the different districts into which the industry might naturally be divided. Private "ownership " would remain, as private ownership remains to-day in the case of the railways, as long as the public chose to tolerate it. But the ownership of capital is no more inseparable from its administration than the military and judicial functions of a mediæval feudatory were inseparable from his financial claim to the rents of his peasants ; and, if administration were shared between the public and the workers in each industry, the shareholders' interest would be attenuated to a mortgage on the product of the industry. The 
subordination of workman to master would disappear in their common membership in an association which stood in a direct relation to the community as its organ of industrial administration. If disputes occurred they would be the disagreements of equals, not the bitter warfare of profiteer and proletariat.

Any reorganisation of industry must not merely satisfy the demand for industrial freedom; it must also supply the machinery through which the public may secure efficient service. Industry, after all, is a social function, and its reform must not merely promise a higher status to privileged groups, but must carry with it an assurance of the subordination of individual and corporate interests to those of the community. 'The mere fact that drastic changes have been necessary in order to secure such subordination during the present emergency, is a proof that in normal times it does not exist. On this point no lengthy argument is needed, because it is self-evident. However the principle that industry is a form of public service may be interpreted, there are, at any rate, three implications which are involved in it. The first is, that the community should be offered the best service technically possible at the lowest price compatible with adequate payment to those who provide it. The second is, that when all charges necessary to the supply of a service have been met, any surplus which exists should pass to the community. 'The third is, that no class should receive an income for which no service is rendered. Vulgar inequality, privata opulentia et publica egestas, the plutocracy which is as distinctive of modern England and America as the Junkerdom is of Prussia, are the visible evidence of the diversion of industry from the performance of public service to the pursuit of private gain. 
Instead of the individual being esteemed for his office, the office is esteemed according as it contributes to the riches or advancement of the individual: and this corruption of the purpose of industry results in privilege, as the debasement of the organisation of industry involves oppression.

Now, in a healthy society, the right authority to hold industry to its proper character of a social function are the persons engaged in it. It is sometimes suggested that if its policy were controlled by those who make things, and not by those who judge it by figures in a balance-sheet and quotations on a market, its quality of a public service would tend to be maintained by the dislike of commercial chicanery, which is natural to most men who make a living by working, and not by buying and selling the work of other people. Whether this is so or not, it is clear that industry ought to be professionalised, in the sense of being governed by standards other than the immediate advantage of the particular individuals or companies who compose it. In matters of price and quality, the public has a right to be protected against the unfair practices of the craft, and the members of the craft have a right to be protected against the unfair practices of one another. Nor is there anything impracticable in such an ideal, however remote it may appear to be from the tendencies of the modern commercial world. It need not be pretended that corporate selfishness can be exorcised by professional rules. What can be created is a corporate conscience, which may be sensitive or indifferent, but to which an appeal on public and moral grounds is possible. There have been ages in which the professions both of medicine and of teaching were rather a mean speculation upon public credulity. And if, while the former has got 
rid of the quack, and the latter of Squeers, the manufacturer still denies the possibility of applying ethical standards to his own calling, and placates his conscience with the maxim that "Business is business," like the Prussian who argues that "War is war," the reason is certainly not that there is anything more sordid in the occupations which are called trades than there is in the occupations which are called professions. Compared with that of a barrister, the work of building a house, or extracting coal, or manufacturing cotton piece-goods, is a school of morals. It is certainly no meaner in itself than is that of attending the sick or instructing the ignorant. It is as necessary, and therefore it is as honourable. Given an organisation of production in which the direction of it was shared between the workers and the community, it would be as possible to work out a code of public honour and recognised obligations in industries as it has been in the professions.

If the conception of industry as a social function is to be effective, it must, then, be a spirit working within it, not merely a body of rules imposed by an external authority. But, in the revolution needed to make the development of that spirit a possibility, the State can, if it pleases, play a considerable part. In the first place, it can insist that industry shall be conducted upon a basis of complete publicity, except in so far as paramount national interests make publicity undesirable in exceptional cases. If industry is carried on to serve the public, not merely for the personal profit of those who supply the capital for it, the community has the right to satisfy itself that the service is faithfully discharged. Unless there is complete publicity with regard to profits and costs, it is impossible to form any judgment either of the reasonableness of the prices which are charged or 
of the claims to remuneration of the different parties engaged in production. In the present ignorance of these crucial elements in the economic situation, most industrial disputes are battles in the dark, where "ignorant armies clash by night." On more than one occasion even during the war, when honourable men might reasonably be reluctant to take advantage of public necessities, both the Government and the private consumer have been charged prices which bore no relation to the cost of production. It is notorious, indeed, that the somewhat tardy adoption of the practice of requiring contractors to submit costings to justify their quotations, has saved large sums to the public purse. There is no reason why those sums should not continue to be saved in time of peace. There is no reason why an Industrial Department should not audit the accounts of all companies, and issue regular reports on the cost of production in different industries, which would enable the public to check the prices quoted. It is a commonplace of democracy that publicity is the best guarantee against political abuses. It should be used as a safeguard against economic abuses. It should be the duty of a government department concerned with industry to publish full reports showing the amount and distribution of the profits made by different trades, and by the individual firms composing them. If it is the case, as is often alleged, that the profits in most industries are inconsiderable, they ought to be known in the interests both of the shareholders and of industrial peace. If they are excessive, they should be known in the interests of the workers and of the public.

But publicity, after all, is no more than an antiseptic. If industry is to be conducted as the honourable social 
function which it should be, it must not merely escape from its rather humiliating tradition of secrecy. Its subordination to the public service must be so direct as to be unmistakable; and the first condition of such subordination is that it should cease to be burdened with payments which are disproportionate to the service rendered, or which are made for no service at all. It must be delivered from the domination of the rentier. For charges which are in the nature of economic rent, or monopoly profits, or which are made merely because one party in industry is in a strong position to corner the market or to drive a bargain, there is no more moral or economic justification than there was for the lods et ventes, or banalités, or vingtaines of the old régime. They lower the economic vitality of society by a double process of exhaustion. On the one hand, they are a mere tax on the community, which is paid to private persons instead of to the State. On the other hand, they enable their recipients to exercise a demand which diverts to the supply of luxuries productive power which would otherwise be diverted to the multiplication of the necessaries of common humanity, so that the classes thus endowed wear several men's clothes, eat several men's dimners, occupy several men's houses, and live several men's lives. The business men and politicians who regard the problem of reconstruction as concerned primarily with intensifying the productivity of industry, may be invited to consider the energy which would be set free for the production of things indispensable, if there were no demand to divert capital and labour into the manufacture of private motor-cars, private yachts, rich men's houses, and expensive hotels.

'The economic waste of functionless incomes is considerable, and in a world that will be obliged, like a platoon 
of soldiers, to sweat for its daily rations, that waste will be felt more severely than in the age of easy-going affluence which ended in 1914. But, compared with their effect on the morale of the community, the mere economic burden of the pensioners of industry is almost trivial. There is much talk at present of the necessity of increasing productive energy. But one condition of more strenuous production is an alteration in distribution. No man will work harder to make necessaries, if he sees that another obtains comforts without working at all. As long as any considerable part of the actual output of wealth goes to classes who, however individually meritorious, have not laboured to produce it, so long will that fact serve as a perpetual discouragement to effort on the part of those who have. The surest way to encourage production is to make it clear that those who do not produce will not consume.

The right principle for the community to follow is simple, though its application may be complex. Though industrial reform cannot be imposed by the State, the State can, at least, emphasise the principle that industry and trade are a form of public service, and that the man who in time of peace plays on public necessities to amass a fortune-the monopolist, or the speculator who corners the market, or the urban landlord who grows rich by other men's industry - is morally on a par with the merchant or manufacturer who holds his countrymen to ransom in time of war. It should, therefore, encourage those types of economic organisation which are likely, by their constitution, to put efficient service before considerations of profit. It should discourage those which are not. And it should regard incomes to which no function is annexed, or which exceed any reasonable interpretation 
of the necessities of healthy existence, as the proper object of special taxation.

The experience of the last three years has emphasised the weakness of the working-class consumer in the face of a general rise in the cost of the necessaries of life. While it is evident that no organisation could have averted such part of the rise as is due to a depreciated currency, or to an actual decrease in supplies through the diversion of production and transport to war and the materials of war, it has been officially stated that some proportion of the increase is due to the action of dealers in playing on the factors, partly psychological and partly economic, of an abnormal situation. 'They have not created it. But they have taken advantage of it, and by taking advantage of it they have intensified it. Whether the responsibility of the private trader for the recent rise in prices be small or great, two facts, at least, are evident. 'The first is, that even in normal times the working-class purchaser, unless she is a member of a co-operative society, is peculiarly helpless. She buys fuel and food in small quantities. She buys much on credit, and finds it difficult to transfer her custom. Her range of purchases is small, and she cannot easily substitute one article for another. 'The second is, that it is often (though not always) as much to the interest of the dealer that prices should rise as it is to that of the consumer that they should not. At any rate, there is no such community of interest between seller and purchaser as to lead the former to act as the business agent of the latter.

Now, price movements are clearly, to a great extent, independent of any particular organisation. It is clearly conceivable that, even if the whole trading world had been striving anxiously during the last three years to keep them down, the increase might have been little less than that 
which has actually taken place. But while it is not possible to give the consumer any safeguard against prices rising on account of scarcity, it is possible to give him a safeguard against such special rises as are not due to unavoidable economic causes. It is possible to offer a check to what is called profiteering. 'The simplest way of offering such a check is, it is submitted, that the consumer should have the alternative of dealing either with a private trader, or with a store which is avowedly and by its constitution concerned, not with making profit, but with supplying the necessaries of life at cost price and no more than cost price. The proper authorities to conduct such stores are the Municipalities. If the retailer is providing an efficient service at reasonable prices, he does not stand to lose by their competition. If he is not, the consumer stands to gain; and if the prices charged at the public store rise, through an inflation of the currency, as much as those charged by the private trader, it is at least the public to whom the profits pass.

What is required is that Municipal Authorities should have power to undertake, if they think fit, the supply of fuel and foodstuffs, of coal, bread, meat, milk, and vegetables. They should also, though for different reasons, be free to purchase and hold land for any purpose that they may please. According to the theory upon which the local government of Great Britain is at present based, Local Authorities, from the tiniest Parish Council to a great Municipal Corporation like Glasgow, Manchester, or Birmingham, can exercise only the powers specially conferred upon them by Act of Parliament. They can do only what they are empowered to do, and if they desire additional powers, they can obtain them only by the cumbersome and exceedingly expensive process of private bill legislation. This strict limitation of the powers of 
Local Authorities dates from the Municipal Corporations Act of 1835, which was admirable in its conception of the machinery of local government, but which was passed at a time when almost the only proper function of local bodies was conceived to be the preservation of public order and the administration of local finances. In an age when Municipal Corporations were corrupt oligarchies, the main object of reformers was not to increase their powers but to diminish their abuses. There is no analogy between modern municipalities and the strongholds of incompetence and privilege which were reconstructed eighty years ago. So far, at least, as county boroughs are concerned, the right principle is not that they be allowed to do merely what they are empowered to do, but that they should be free to do anything which they are not forbidden to do. Central control is necessary, in order to ensure that posterity is not burdened by excessive capital expenditure, to preserve a minimum standard of efficiency, and to adjust the claims of conflicting authorities. But, provided that these conditions are satisfied, there is no reason why the great Municipal Corporations should not undertake such services as the inhabitants of these areas may from time to time desire. 'The pretension of Parliament to protect the citizens of Manchester or Birmingham against themselves is at once impertinent in itself, and fatal to the spirit of initiative and experiment which is the condition of progress. Great communities like these cities should be free to develop their communal life in the directions in which they think best. In some respects their public spirit and civic intelligence are distinctly higher than those of the House of Conmons. They should be given free play for the work of reconstruction. If reconstruction is to be a reality, what is needed is not merely to inaugurate such reforms as can be squeezed through the bottle-neck 
of a central government which tends to view the domestic problems of England under the optical illusion created by residence in London, but to liberate political energy, and to untie the hands of local bodies in order that they may be free to find the solution of their own problems. Such a problem is the discovery of an organisation of retail trade such as may ensure the cheapest supply of the necessaries of life which is economically possible. No more efficient check upon exorbitant prices could have been devised during the recent crisis than the establishment of municipal shops where food and fuel could have been obtained at cost price.

'This development of economic enterprise on the part of municipalities, though already not uncommon in countries in which the tradition of administrative centralisation is in some respects much stronger than it is in England, would be in the nature of a novelty. The extension of national control over foundation industries would not. During the past three years the nation has been obliged, in mere self-defence, to live by the principle that industries on which the public safety depends must be carried on primarily for public needs. Sometimes, as in the case of some textile industries and the manufacture of boots and shoes, the Government has purchased the raw material and rationed the individual manufacturers. Sometimes, as in the case of munition factories, it has "controlled" what were previously private establishments. Sometimes, as in the case of the railways and of the coal-mines, it has virtually nationalised administration, while leaving the ownership of plant in private hands. Sometimes, as in the engineering trade, it has nultiplied national factories.

The wisdom of adopting such emergency measures in time of war does not prove, of course, that it would 
be wise to adhere to them in time of peace. Nor does the change in the relation between the industries, as a whole, and the State which they involve, offer in itself any solution of the problems arising in connection with the status of the workers within them, or from their relation to the management. As a criticism upon the suggestion that the nationalisation of industries, however complete, supplies a formula of emancipation to the wage-earner, the recent reaction against collectivism has been valuable and instructive.

Whatever the authority to whom industry is ultimately responsible, the problem of its proper constitution and government will remain for separate solution. But it is not, except in the single instance of the coalmines, from that problem that the motive to recent experiments in the public control of industry has arisen. 'Their rationale has been the necessity of finding some guarantee of economical and effective public service more reliable than the competition, or absence of competition, between separate firms. The worker, qua worker, is not directly benefited by an extension of public control, though, once civil liberties are restored, he is not likely to be prejudiced by it. The cause to which it is designed to contribute is the public interest in efficient production.

What was necessary in war may not be necessary in peace, but it may continue, with modifications, to be desirable. In the period of recuperation it will obviously be of urgent importance that there should be the fullest possible utilisation of every aid to efficient production. The foundations of modern manufacturing industry are cheap raw materials, cheap coal and iron, cheap power, and economical and effective methods of transit. Every unnecessary payment in the production of coal or iron, 
in the transmission of power, or in the conveyance of goods, is reflected in an increased price, not only of the articles immediately concerned, but of all the articles into whose cost of production they enter. But what guarantee was there before the war that these indispensable services were supplied at the lowest rates compatible with a liberal payment to the workers engaged in rendering them? They may have been; just as it may have been necessary during the war that some shipowners should make from 50 to 100 per cent. upon their capital in order that the nation of which they were nominally the citizens might obtain the goods necessary to save it from starvation and defeat. But to the eye of sense that is not the conclusion suggested by an examination of the facts. Consider, for example, what is the first stage in production-the supply of raw materials. A considerable number of these are now bought in bulk by the War Contracts Department, and distributed to the different industries using them. The economies effected since that Department was established are an index of the unnecessary charges borne by industry, and therefore by the consumer, before its establishment. The report submitted in June 1917 to the Public Accounts Committee shows, indeed, that prices have been reduced by the institution of a system of costings in the case of finished articles:"During the twelve months ending the 30th of April 1917 , the cost of contracts for these stores, to the value of $£ 8,500,000$, was investigated, and reductions were made amounting to $£ 408,000$." But it shows a much more significant fact. It is that the department has been able to reduce prices by controlling the supply of raw materials. Thus, in the case of wool, "an estimate of the economies effected, as compared with the prices which the department would have to pay for the manu- 
factured article had the industry not been dealt with along these lines, is put at $£ 13,000,000$. In the case of leather, "the saving here alone is over $£ 3,000,000$. Again, without counting the receipts from the sale of by-products, it is estimated that the control of Indian clips has resulted in an economy of $£ 1,125,000$." "The control of manufacturing processes in the case of jute has

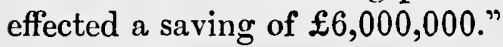

A similar comment upon the commercial organisation on which the supply of coal depends, is offered by the scheme put forward in July 1917 for a more econonical system of distribution. The wastefulness of the old order is indicated by the measures now enforced. Nor is the waste confined to distribution. What the actual figures tell us with regard to the coal-mining industry is that the average pithead price of coal was, in 1913, $10 \mathrm{~s} .1 \frac{1}{2} \mathrm{~d}$. per ton, and to the consumer somewhere between 16s. and $20 \mathrm{~s}$; that out of the sum of $£ 230,000,000$, which is the annual coal-bill of the nation, about $£ 90,000,000$ goes in wages, about $£ 36,000,000$ on other working costs, about $£ 16,500,000$ on profits, including royalties and way-leave, and the remainder on conveyance and distribution. What the probabilities of the case suggest is that the raising of coal by about 1500 different companies from the 3300 pits which are worked, its haulage in separately owned trucks, and its sale by innumerable independent dealers and merchants, sometimes competing and somctimes in a more or less informal combination, is not likely to be the most economical way of putting it at the service of industry and of the individual household. The memoranda submitted to the Board of 'Trade Railway Conference in 1909 by railway managers emphasise in the same way the wastefulness arising from overlapping and duplication, 
and draw attention to the advantage to the public of a unified service.

Economy and efficiency are not the last words in industry. It is more important that its organisation should be such as to offer the worker what has been called above the conditions of corporate freedom, than that it should function with a mechanical efficiency, if efficiency can be purchased only by an inhuman rigidity of discipline. But, on their own plane, economy and efficiency are important; and, happily, the choice between these qualities and the control by the workers of all grades over the day-to-day administration of the industry is not one which need be made. Indeed, what impedes such a reorganisation of the greater industries on the basis of corporate self-government is precisely the industrial autocracy which, there is reason to believe, also prejudices the service which they offer to the public. To that extent freedom and function go together, and erery measure which makes the coal-mines or the railways the property of the community would, at least, facilitate, though by itself it would not ensure, wider opportunities of industrial self-government to miners and railwaymen. In maintaining and extending its control over industry, the community could, therefore, meet the demands both of the worker and of the consumer. It need not choose between subjecting the former to a new clerkocracy and leaving the latter at the mercy of competition qualified by more or less monopolistic combinations. What it can do, is to maintain the interest of the general public in sound and efficient service, while leaving the maximum liberty to those in the industry to determine how exactly the service shall be organised. If it adopts this standpoint, it will naturally not abandon the claim to a kind of eminent domain over industry which has been established 
during the war, but which had, in fact, been in gradual preparation long before the war began. It will continue, by organising the supply of raw materials, to secure for industry the advantages of large sale purchases, and incidentally, by eliminating speculation, to confine the employer to his proper function of a specialist in industrial administration. And it will continue to treat the railways and mines as public services. But it will devolve as large a share of administration as possible upon those actually engaged in the industries.

Such reforms imply a change in the public attitude, not only towards labour, but towards property. And, in the England which existed before the war, to touch property was to sport with lions. Mankind is moving in uncharted waters, and is as likely to exaggerate, as to underestimate, the change in its psychology induced by the voyage. It is possible that the pathetic instinct to demand payment for privilege, as though it were a kind of service, will re-emerge jaunty and unrepentant out of the sea of blood and tears in which it has been temporarily submerged, and that in a world where not a few have given all, there may still be classes and individuals whose ideal is not to give but to take. Such claims, if they are made, may be regarded with pity, but without apprehension. Men who have endured the rigour of war in order to make the world safe for democracy, will find ways of overcoming the social forces and institutions which threaten that cause in time of peace. 


\section{VI}

BY F. DUDLEY DOCKER, C.B.

There is no doubt that the outbreak of the present European War occurred at a very critical period in the history of Great Britain. There was immediate danger of civil war in Ireland, and throughout England, Scotland, and Wales class antagonism had reached an acute stage. A long period of prosperity threatened to produce, in this country, something like industrial decline; a spirit of slackness was becoming apparent, keenness of competition was not appreciated, nor was the growth of inventive genius. In short, the trading efficiency of the country was waning, and distrust and suspicion between masters and men had produced friction which might easily have developed into warfare.

This class antagonism may have been the result of the change in the trading conditions during the preceding quarter of a century. The workman had been removed from immediate association with his employer, and managers and foremen had taken over many of the duties which our grandfathers discharged themselves. Changes in society and in habits of life during the twenty-five years immediately preceding the war, and the growth of education, had altered the whole outlook of the workmen, who desired to attain to a higher standard of comfort, 
and unfortunately, in many instances, these well-founded aspirations did not receive encouragement and sympathy from the employers.

The outbreak of war diverted attention from domestic troubles, and it will be well if we can turn the interruption to good account. We might begin by getting rid of some of the ill-natured and small-minded criticism that is so common. Let people realise that the soldier who has excited world-wide admiration by his pluck and endurance on the field of war is the same person as the British working-man at home. Let the soldier, when he comes back, remember that his employers are frequently the same officers who, when weary themselves, cared for the wants of their men first, and are the same officers who led them to victory. If these conceptions be honestly attempted, the difficulties to be faced after the war can be regarded with equanimity, for their solution will be brought about more from sympathy than by economic force. We have already shown that it is possible for us in times of danger to sink differences, and, irrespective of opinions or creeds, to combine to fight and resist a common foe. The men who have fought side by side can live in peace together. 'This is not the place in which to extol the efforts that have been made on all sides, but the one point that concerns this paper is the extraordinary adaptability that has been shown by British trade to face and cope with altered conditions. After a period of disorganisation it dawned at last on Great Britain that the mechanics of warfare were as important as the personal element; that superior equipment would tell its own talc, and that the forces of industry of the belligerent nations must engage in as keen and bitter a conflict as the armies in the field. There was a wonderful reawakening- $-\mathrm{Mr}$ Lloyd George says, " IVe are a different people." 
Peaceful occupations were, at the call of the nation, deliberately put on one side; employers undertook contracts for the production of warlike stores without any previous experience to guide them. Old plant and machinery were scrapped, and sluggish habits were got rid of. The efforts of the employers have been nobly seconded by the workpeople, who have, without hesitation, pursued new trades and acquired a skill with which they were never previously credited. Indeed, to accomplish this, they have, at the call of the Government, abrogated established trade practices which have been built up as the result, in many cases, of bygone struggles. The employers have submitted to their establishments being taken over and controlled by the State, and to the surrender of the greater part of any profit resulting from war work. There can be no doubt that the excess profits duty and the munition levy have pressed very hardly upon many manufacturers. 'The pre-war standard on which profits were assessed has, in many instances, proved an unjust one, and there are many cases in which the manufacturer is actually penalised for the efforts he has been making to assist the nation. Moreover, he has had to submit to frequent and unnecessary inspection from officials whose ordinary vocations did not fit them to undertake the new duties imposed upon them, and whose visitations to works have been accompanied by want of tact and an inability to understand working conditions. To say these inconveniences have been generally cheerfully endured is greatly to the credit of the British manufacturer, especially when it cannot be denied that in very few instanices has he been consulted in the smallest degree as to any contemplated changes, either technical, administrative, or legislative.

On the whole, the working-men have played their part 
well, and it was not until the nervous strain became severely marked that there were any disturbances and strikes. Latterly, these have been of frequent occurrence and of dangerous dimensions, and they have not been obviated by the action of the Government in making constant concessions and alterations, and by frequently raising the rate of wages. Perhaps the most perplexing feature of these labour troubles has been the evidence they have afforded that the rank and file of workers no longer place the reliance they formerly did in their Union leaders, but are inclined to break away from any bargain on small provocation. It is also remarkable that although every large works is controlled by the Government, and the employers are only acting under orders, the disputes with the workmen have been more frequent than when the employers were their own masters!

With these things in mind, let us try to forecast what must be faced after the war. There is no doubt that competition in trade will be keener than it has ever been before. There will be a general scramble for the markets of the world, and a period of bitter international competition. An effort will no doubt be made, in accordance with the lines of the Paris convention, to arrive at a modus vivendi between the present allies. What will then be the position of Germany? We know that, notwithstanding the enormous strain that has been put upon the German Empire to carry on the conflict, and to cope with her antagonists all over the world, she has nevertheless been preparing for the commercial warfare into which she will be flung as soon as peace is declared. She is not going to surrender the industrial position she has built up with so much care and ability during the last quarter of a century. Her efforts during that period, at efficient industrial expansion, have excited 


\section{THE EMPIRE AND COMMERCIAL SUPREMACY 133}

the envy of every thoughtful British trader. Her foreign trade was conceived and carried out on lines never attempted in this country. 'There was no parsimony about it; money was spent freely with the one object of developing foreign trade for the good of the whole German people. The Government was in close touch with the efforts of the trader, and gave him financial support. which British bankers would have deemed imprudent. With this experience, and realising the thought and concentration that he has given to the subject during the past three years, we must expect that the German trader will be in a very strong position to resume his activities after the war. His avowed object is, "All for Germany," and to that end he will push every branch of industry. He knows that mechanical efficiency and productivity go hand in hand. His great effort will be to produce, for unless he can produce he cannot secure trade. In order that he may produce, it is not too much to believe that he will pay any wages and use aly incentive to increase his output, and then probably will offer his wares at considerably below cost price to secure the market.

How are we going to meet this state of affairs? What can the Empire do to regain commercial supremacy? First, it must not allow the methods born of war to fall into disuse; the equipment of the industrial armiy must be up to date; there must be boldness of initiative and fearless rejection of obsolete methods, but foremost, it is absolutely necessary that the productivity of labour should be increased. 'This can only be achieved in one way - by sound and amicable relations being established between Capital and Labour. The first consideration must be to allay the distrust that exists between all classes in the industrial world, and to do 
this there must be a reorganisation of the whole fabric of trade.

'The workmen have a right to expect a greater share in the results of their work, and a higher standard of comfort than they have formerly enjoyed. In the opinion of the writer there can be no return to the old rates of wages and pre-war conditions, nor is there any reason why there should be such return. It is a mistaken idea to assume that there should be a hard-and-fast line that constitutes a standard wage, and beyond which no man can go. A man has a right to all he can earn, and it is not honest for the employer to endeavour to thwart his workpeople by cutting the rates as soon as the workman has attained such a degree of proficiency that he can pass what has been set up as the standard rate. The vital thing for the manufacturer to watch is not the amount he pays per week to any particular man, but the cost per unit of production. The greater the amount the workman earns, the less is the cost of production for more will have been produced. The difficulty is to induce the workman to do as much as he can. There is an instance known when the workmen "knocked off" work at 3 o"clock in the afternoon to avoid earning enough to make them liable for income tax.

Of quite as great importance is the attitude the employer must assume with regard to his workpeople; there must be more human feeling, and allowance must be made for the nervous strain and the irritating conditions under which the work had been carried on for the last three years. When peace comes there is bound to be a reaction. Everyone-employers and workpeople alike-will require relief from the tension, and it will be well to recognise any spirit of lassitude that may prevail, or any desire to indulge in holiday-making. 
Without doubt the first year after the war will be the most difficult for the manufacturer, for he must deal leniently with the considerations just stated, and must, in addition, reorganise his works.

Of more lasting importance, perhaps, are the housing conditions under which the operatives live. While enlightened employers have in many instances recognised their responsibilities, it is not incorrect to say that generally the housing of the artisan attains a very low standard. It would be a pity that this condition of things should be remedied wholly by the State. It is true it is of national importance, but it is, nevertheless, the duty of the employer to give facilities for the erection of decent dwellings, so that the home life of the workpeople may be more comfortable than it is now.

To attain these objects at home, and to combat German competition in this country and abroad, the produce of labour, as has been indicated, must be vastly increased. The structure of British inuustry must be re-established. The business which, standing alone, cannot provide adequately for master and men, must be joined up with other undertakings so that waste may be prevented, and national welfare increased. 'The works themselves must be reorganised, and brought thoroughly up to date. The old machinery and plant which has been made to do, must be scrapped without hesitation, and new methods and recent inventions must have full scope.

The introduction of new machinery has always, in the past, been attended with great difficulties. The almosi inevitable consequence of new machinery is to dislocate Labour. Various theories have been advanced by both masters and men; it has been contended by the 
master that there is no real displacement of Labour, for what labour was set free by the introduction of improved plant could be used to augment some other branch of industry. On the other hand, the Trades Unions have resisted the introduction of new machines on the ground that they created unemployment, and thus brought immediate charge on the funds of the Trades Unions concerned. Neither of these theories is somd, and each is narrow in outlook.

There must be increased productivity, and to ensure this there must be more fluidity of labour. Means must be devised whereby the transference of men can be accomplished without lowering wages or increasing the burden of charges for unemployment. The fear of displacing labour is generally exaggerated. Experience shows that the introduction of new machinery means, as a rule, increased business. The manufacturer will not put down new plant for any other object. The result usually is that the number of men employed is largely increased, though perhaps fewer hands are working each machine. The main object of all industry is to produce more, but at the same time it must not' be forgotten that the laboursaving appliance or the improved method of production is not really labour-saring until the displaced labour has been reabsorbed in such a manner that the increased produce of the labour remaining in the old channcl, added to the output of the transferred labour, is greater than the total production before the new method of labour-saving was introduced. It therefore scems clear that the first claim against such increased output should be the support of displaced labour until that labour has becn reabsorbed. There should be no clain by either masters or men to the results of labour-saving methods until these conditions have been fairly met. 
It would be possible to arrange with the Unions for a contribution to be made to the unemployment benefit funds whenever new machinery is introduced that displaces labour. To deal adequately with these questions of the transference of labour and the contributions by employers, it is essential that the Unions must be federated and strengthened, and also that there must be proper associations of employers capable of making bargains on behalf of the manufacturers. It is obvious that only when negotiations are conducted by bodies that are really great and strong, can rules be adjusted for securing increased output and adequate remuneration.

The question of unemployment is a matter that can be dealt with by organised employers and Trades Unions acting together. No other way will secure the fluidity of labour, and in no other manner can difficulties as to masters' contributions to unemployment benefit be overcome. Jealousies between the Unions themselves would disappear if the Unions were federated and unemployment funds pooled and centralised.

It would be a national disaster if labour, which has proved itself so adaptable, should be allowed to slip back into old groores, and be hampered by trying rules and restrictions. To prevent this, a strong effort should be made to reform 'Irade Union rules as to apprenticeship, and, wherever possible, men should be encouraged to learn a second trade. There is no need for the Government to interfere in these matters; they can all be adjusted by employers and employed acting in unison, with sufficient imagination to realise the full bearing of the question and the points of view of the persons interested. Nothing is to be so much deprecated as undue Government interference in matters affecting trade and industry. 
It destroys independence and self-reliance, and saps initiative.

There are, however, directions in which the legislature and the Government can prove of immediate benefit to trade. Of what use will it be to stimulate the productivity of labour by the introduction of better machinery and organisation, if the British manufacturer is to be hampered by unsatisfactory consular arrangements, and by the absence of any tariff enabling him to strike a bargain? The whole of our consular system must be overhauled and placed on a sound basis, with arrangements for securing commercial intelligence of a reliable and useful character. This the Germans provided without stint, and to their great advantage. There is not space to argue the merits of free trade and tariff reform, but after the experience of the last few years, there is no manufacturer who fails to recognise that the German trade organisation is a war organisation, and can only be met and defeated by warlike methods; and unless the British manufacturer is armed with a tariff club he is impotent, and his brains, his capital and the labour of his workpeople are of no account.

'There is, moreover, another subject upon which the Government and all classes of industrial life must unitethe improvement of our educational system. Money must be spent frecly to remodel our organisation and to make it serve the needs of industry. The curriculum must be revised-the school-leaving age advanced-and last, but not least, the calibre and quality of the teachers improved, and greater emoluments and prospects offered to them. Moreover, it is submitted that industry has not been able to take full advantage of the education offered, through lack of facilities for transferring students from the educational establishments to the posts for which their train- 
ing has best fitted them. This has led to a great number entering the professions, and very few returning to industry. The establishment of an Appointments Board at every university, similar to that existing at Cambridge, which would be responsible for retaining a complete record of all the students passing through their hands, and personal comments on their general capabilities, would obviate this difficulty. A central clearing-house would be essential to which manufacturers could apply; this would be kept supplied by the Appointments Boards, with lists indicating the training and suitability of persons to various posts.

It is frequently stated, and with truth, that the life of the workman is monotonous. Unfortunately it is inevitable that the doing of repetition work from year's end to year's end, in drab and uncomfortable surroundings, must be monotonous. It is to the interest of every manufacturer to make his workmen happy and contented. The sovereign remedy would appear to be to stimulate his ambition. To do this he should be allowed to know more of his trade, to understand the relation of markets to prices, and, in short, to realise that he is only one of a team, and that his little bit of work is of importance to the whole undertaking.

If this idea of partnership be fostered, and if care be taken by the employer to see that housing arrangements are adequate, there will be great improvement in the workman's lot. It will not accomplish everything, as unless thrift and house pride can be instilled into the wives, all the endeavour of the employer for his men will be in vain, for it must not be forgotten that the domestic discomfort of the working-man is not entirely attributable to bad housing and dreary surroundings.

No claim to either originality or freshness is made 
for the suggestions and comments in this chapter, but so much misunderstanding exists, and so many misstatements are made that the writer puts forward his views and makes bold to claim that they are the opinions of the majority of employers. 


\section{VII}

\section{By F. S. BUTTON}

ThE need for industrial harmony immediately' after the war appears to be accepted by all parties concerned, if we are to judge by the numberless schemes formulated and in process of formation.

In considering the position, I think we should first ask ourselves:-Is existing machinery for negotiation sufficient for the purpose of securing and maintaining industrial peace? Can reliance be placed on the existence of any sort of good-will between Capital and Labour? What attitude will be taken by the parties on the question of a continuance of compulsory arbitration in regard to wages and technical trade questions? Has the point of view of Capital undergone any change with reference to joint workshop control and co-operation in industry generally, and has Labour changed its attitude towards profit-sharing and co-partnership?

Again we may ask:-Can fair play in the workshop be guaranteed by the appointment of a Labour official? Should such an official be nominated by the Trade Union and appointed and paid by the employer? Can a proposal be tabled which will cause the trade unionist to take a keen and active interest in the development of industry; give an assurance of continuity of labour; deal with the problem of unemployment; place some 
limit, either on a voluntary or a legal basis, on the powers and functions of Capital and Labour, having regard to the communal interests represented by the State; afford some guarantee of workshop harmony by dealing with points of difference as they immediately arise; and give to Labour some real and permanent share in the greater productivity resulting? These and other questions we will examine and attempt to find an answer to.

In the first place, it appears necessary to state that the Trade Unions are not enamoured of proposals for securing industrial harmony by any sort of State interference or compulsion whatever. Nor is Capital I imagine. No surer way of wrecking any scheme could be found than the attempt to enforce a cut-and-dried set of proposals on the parties from without. The essence of a durable working scheme is that Capital and Labour should have been afforded the opportunity of welding together their opposing ends of the rod on a mutual anvil.

Political arguments as to the need for national efficiency and the maintenance of Britain's rightful place in world markets will fall largely on deaf ears, unless some real compensating advantage is offered to Labour. The only hope for the cessation of hostilities which can be offered with any security that Labour's instinctive opposition will be overcome, is by the granting of some real measure of workshop control. How can this be accomplished? Are the 'Trade Unions ready to consider such a proposal: What is the attitude of the man in the workshop? Consider what he has given up during the war period for the benefit of the State! Such sacrifices entitle him to be critical!

Introduce piecework, the premium bonus system, or any other seheme of payment by results; give no 


\section{POSSIBILITIES OF INDUSTRIAL HARMONY 143}

guarantees against unemployment; offer no reduction in hours; fail, except by way of full discussion and complete agreement, in any essential measure to return to the status quo ante bellum; above all, grant no measure of real control-and the craft unionist will say: "Have we given up all for this? Are our vested interests in the trade and our monopoly in skill so undervalued by the powers that be, and worth no more to us than this mess of pottage in the shape of maintaining commercial supremacy in world markets?" Under such a condition of things surely the industrial thunderbolt will fall. Are the relationships of Labour and Capital on a sufficiently cordial basis to warrant us in any other assumption? Is there any promise of permanence in the present seeming harmony? I think not. At the end of the war neither Labour nor Capital will be in the mood for negotiation. Both sides will be in a state of some considerable physical and mental exhaustion. Repressive legislation, acquiesced in by Capital and by Labour, and in some respects with a surly and half rebellious acceptance, will have fallen in, and the external cementing pressure of a relentless foe will have been removed. Is there no policy which can be adopted for the prevention of the inevitable industrial Armageddon?

No universally applicable scheme can be formulated. Each industry, and often each section of an industry, must be sectionally dealt with. In this essay, the possibilities of industrial harmony in the engineering trade are considered. I think, however, that many of the suggestions here offered may be found useful in any well-organised industry, but, necessarily, the parties, when brought together, must thrash out their special problems to their mutual satisfaction.

Even in the trade under consideration, the scheme 
may require modification, or extension, in some respects in shipbuilding, and the particular methods employed in railway shops will not necessarily find acceptance in upto-date tool-rooms. Again, the proposals agreed upon as workable in such productive Government establishments as the Royal Arsenal, the Royal Small Arms Factory, and the Royal Aircraft Factory, whilst suitable to the national shell factories which remain, will differ in basis and methods of control from such other Government productive departments as are represented by the royal dockyards. In such Government factories the State would, necessarily, have a larger voice in appointment and control than in privatelyrun concerns. It may be that the matter from the point of view of political influence will, in this connection, have to be considered. I am not in any case sanguine that the State will lead the way as the model employer. To those immersed in the regulations and methods adopted for Government production, it might well seem that the absence of profiteering would justify the conclusion that a greater measure of co-operation could here be found. Undoubtedly, the attitude of mind of the workers in these establishments differs from that of the men employed in private factories and yards. The absence of mental anxiety in regard to unemployment on the part of large sections of the workpeople concerned, entitles one to conclude, I think, that a successful cxperiment could, in this connection, be attempted. 'Ihe workers are well organised in Trade Unions, and well disciplined as producers. Can no man, or no body of men, be found to apply the match to the existing winding-sheet of red tape which successfully prevents so much potential co-operation?

In returning to the industry as a whole, it seems necessary to link up proposals in an endless chain. 
There must be no gaps and pitfalls, and the basic principle must control all its parts. The scheme, as here outlined, will, I hope, be fully considered and tested. We may trust that the National Industrial Council here suggested will attract, or produce, the best men on either side, and that it will afford an outlet for much social energy now lying dormant, or exercised in less useful directions. Pride in the industry and a just recognition by the State will serve as twin levers for a lofty conception of duty. The Local District Committees will serve as the training-ground. Where all have a chance all will fit themselves. The man of business will lose some of his selfish concentration, and the orator gain a grip on practical administration. Each will understand the other better. No other scheme could establish for long more than a patched-up harmony. The Works Council will separate the technical expert and the specialist in factory organisation from the man whose bent is in the direction of social work and Trade Union government. The former will buttress and add to the power of Capital; the latter will bring a trained mind to bear in departments of activity now run almost entirely by rule of thumb. The Works Committee will afford an opportunity to men of constructive ideas, and provide an outlet for the superabundant energy of the type who to-day are the despair of those responsible, in any way, for orderly and disciplined government, whether of the Trade Union, the industry, or the nation. Let us look at the scheme as an intelligence department and a clearing-house for constructive ideals. In any case, the community gains by a more enlightened citizenship; and the definite raising of the status of Labour may have results at present almost undreamed of.

The question must be asked, Can reliance be placed 
on the present existence of good-will between Capital and Labour? It seems fair to argue that, on the present basis of production and distribution, what good-will exists will afford a very insecure prop when the stress comes. But such good-will as does exist should be used as a lever to establish permanently satisfactory relationships now. It may be easy to over - estimate the advantages of immediate action, but that such advantages exist at the present moment I think no one understanding the situation will dispute or deny. Some employers are inaugurating a new Labour Department, and invariably you find a resigned Trade Union official at the head. Some employers, as a first proof of their enlightenment, are proposing to introduce a representative trade unionist as a rate-fixer, to exercise functions, it is to be presumed, similar to those of the check - weigh man at the mine. Will the trade unionist be prepared to accept these schenies as the final word in the assurances given of fair play? I think not, indeed I hope not. The only guarantee is through a committee. The individual shop steward has aroused the opposition of the employer in the past, and the individual Labour official will be no more successful from his particular point of view in the future. Can such a proposal afford a gieater promise of success if the Trade Union nominates the official? I believe not. If the Trade Union appointed and paid the official, and the men concerned had the right of acceptance and removal, something might be said for the scheme, strictly from the 'Trade Union point of view; but no present employer would agree to such a proposal, and would certainly wreck it if adopted under any form of compulsion.

We decide, then, that Capital and Labour must be brought together. How is this to be done? Who is to 
assume the responsibility? Capital will not, and no representative body of trade unionists appears to be ready. Neither Capital nor Labour in the bulk is an apt pupil at the present time. A conscious laying of party and sectional plans may be, and probably is, going on, but a definite and real endeavour at a mutually constructed plan must be attempted. Surely we may expect the State to enter here! For what great purposes of State was the Ministry of Labour set up? Are community interests never to be considered, except when potential belligerents commence actual fighting? Community interests must be at once the excuse and the justification for intervening. The apparently purely private interests of Capital and Labour must be viewed in their true perspective; and the only person with an assured detachment of mind is the looker-on. Then let the authoritative looker-on, who by our philosophy should be the Minister of Labour representing the State, charged as he is with communal interests, step in and order the parties to meet. Let him table the framework of the scheme. Neither Capital nor Labour will assume, nor is it fair to expect them to assume, responsibility for opening negotiations on vital principles. The democratisation of industry must be the corner-stone of any and all proposals. Nothing else will do; all else will be regarded as sham and make-believe, and cause Labour to be rigidly and permanently hostile.

But can a real measure of control be granted to Labour without endangering the stability of the industry concerned? Will the man in the workshop give his co-operation for less? In reply to the first question, I assert that what stability industry at present possesses is undermined and menaced, and that there is no hope for orderly progress unless new basic methods are adopted. 
Only through a real measure of democratic control being granted to the worker can the industry rest on any sure and lasting foundation. Given such a scheme of industrial government, the reply to my second question is assured. No other price will purchase the workman's willing service, and if his good-will can thus be secured our consideration of the matter is thoroughly worth while. National as well as industrial well-being is bound up in the proposal. It is therefore incumbent on all public-spirited people to interest themselves in the problem.

But care must be exereised not to impose statutory and binding conditions on the parties. 'The best guarantee that agreements will be kept is not the sanction or enforcement of the law, but the voluntary loyalty of the parties eoncerned. Put the parties, not on the end of a chain, but on their parole. Industrial agreements, based on honourable acceptance, were rarely broken by either side before the war. 'The attempt to enforce an industrial peace by Act of Parliament or Privy Council regulation has, during the war, proved a very weak reed upon which to rely. Our present system of production and distribution must be humanised. Give the best elements of both sides a ehance to develop and exercise, and then stand aside and wateh the industrial revolution take place on a peace basis. In some of the less well organised trades than that with which we are occupied, some legal sanction for the enforcement of agreements may be found needful, and the basis of workshop control may differ widely from the proposals herein set forth. But in the engineering trade an ounce of discussion and mutual agreement will be worth a ton of legal enactment.

But surely the development of the trade must not be 
our only concern! The State, the employer, and the trade unionist must not overlook the individual and social value lying ready for use in these proposals. The unlocking of potential mental vigour can be looked forward to by all those who have the well-being of the people at heart. Agreement will be reached only when all the cards are displayed, and every expert opinion-or, for that matter, uninformed prejudices on both sides-have had their full chance to find expression. And agreement so reached will be honourably carried out. New standards will be reached, and none can foresee the possibilities which lie ahead.

In contradistinction to this method, any superimposition of legal enactment, however inherently just, will lead either to an attitude of mental dependence, or, what is much more likely to be the case, to the adoption of a policy of incipient rebellion on the part of Labour. In any case, the safe line of real advancement appears to be to rely on the corporate interests of the individual and afford an opportunity for regard to be paid to the larger issues involved both from the point of view of the trade and the Trade Union.

In so far, then, as the present method of industrial organisation entitles us to assume the existence of a desire for co-operation, and its development and extension, between Capital and Labour, the institution of the following bodies seem to me to contain the surest promise of fulfilment :-

1. Workshop Committees.

2. Central Works Councils.

3. Local District Boards.

4. National or Industrial Councils.

We will proceed to examine these proposals in detail. 
In doing so our object should be to provide a remedy for industrial unrest, and not to try and achieve, by coercive measures, a false and insecure industrial peace.

Though we must analyse, in the coming pages, the scope and utilisation of the strike weapon, our object should be, I think, to set up such normal relationships as will guarantee the full exhaustion of methods of accepted negotiation before any resort to force is permitted or adopted by either party. We must avoid the setting up of any machinery which will rob the employer of the right to lock-out or the workman of his right to strike, only endeavouring to render sure the opportunity for the use of the strike weapon as a last resort when all available negotiation has failed.

Workshop Committees. - The greatest importance should be attached to the setting up of such committees in the workshop. In the past the mole-hill has grown into the mountain before intelligence has been applied to the problem, and then, often, it has been found to be too late to stem the tide of rebellion. Misunderstanding, irritation, strained relationships, and empty cupboards have been too frequently the result. The value of the proposal to establish Workshop Conmittees is that matters will be dealt with as, and when, they arise.

The granting of such an advanced status to Labour will be found to be a real asset to industry and to the workpeople concerned. The employer, in the past, has been conservative, and even to-day is somewhat afraid of new ideas-at least when they encroach upon his managerial preserves. He offers the opinion that his workpeople will never be capable of achieving responsibility. Have they not always in the past met him, not with proposals to help, but with a demand in their hands? And the best points of employer and workman are hardly 
likely to be developed in conferences where one side demands and the other rejects. A new atmosphere and a new relationship are necessary. The old insecure foundations must go. In return for the workman's co-operation, a democratic basis for industry must be conceded. If the workman's co-operation is thereby secured, is the price asked in the proposals here set forth too great?

The Workshop Committee should comprise representatives from the management and the workpeople in equal numbers. The management should choose their own representatives, and the workpeople should elect their representatives by ballot. Care must be taken to make provision for Trade Union representation, but only in the less well-organised trades need it be considered whether an outside official of the Union should have a seat on the committee. Each side should appoint its own chairman and secretary; and each side should submit its agenda to the other for discussion at joint committee meetings, which should be held at least once in every week during workshop hours.

The following, broadly, are the terms of reference that appear to me to be wanted:--(1) Improved methods of manufacture, tools, jigs, gauges, and to make suggestions thereon; (2) new methods of production; (3) class of labour to be used on new types or reconstructed machines; (4) criticism and adjustment in existing piecework prices or premium bonus basis times, due regard being had to the custom of the trade, locality. or shop on the question of a guaranteed time rate; (5) co-operation with the management in supervision: (6) shop troubles and grievances; (7) suspensions and dismissals consequent upon slackness in trade; (8) shop rules-timekeeping, meal hours, cleaning-time, clock allowances, changes in starting-time; (9) suggestions 
to change the method of remuneration from day work to systems of payment by results, and vice versa; (10) the problem of the disabled soldier and sailor, due regard being had to any general plan agreed upon by higher authority; (11) matters relating to welfare; (12) demarcation between trades with the free sanction of the Trade Unions concerned; (13) advice on workshop conditions and other matters affecting labour.

The committee must not interfere with recognised Trade Union practices, nor deal with matters covered by agreements, except with the approval of all parties concerned. The method of appointment should be carefully set out, and it should be clearly stated whether the unorganised, as such, are to be represented. The number of seats allocated to craftsmen, to the unskilled, and to the female workers will vary in different establishments. In the majority of engineering factories and shipyards, if there is a ballot vote, in which all can join in the election of persons who have been democratically nominated, no friction or failure to secure loyalty need be feared.

The Central Works Councils.-Where, owing to the manifold departments, or the complex organisation of the works, it is necessary to set up more than one Workshop Committee, a Central Works Council should be formed. This should be representative of each of the panels which form the different Workshop Committees. 'The basis of representation should in each case be the same, but the total number of representatives from each Workshop Committee might vary in accordance with the size or importance of the department concerned. The Board of Directors, or local association of employers, should appoint the chairman for its side; and the Trade Tnion should choose a representative workman, employed 
in the factory concerned, as chairman for the side of the workpeople.

The council should sit during factory hours to deal with the following matters:-(1) To consider reports from Workshop Committees ; (2) refer back unadopted portions of report to shop committee concerned, when its representative offers reasons for rejection ; (3) decide matters from such reports which affect the factory as a whole, as distinct from the shop; (4) generally to assist the management in matters relating to production and organisation; (5) initiate reforms arising out of new legislation affecting factories and workshops; (6) assist after the war period in the resumption of existing laws; (7) consider matters referred to them by the Board of Directors or either panel of the Workshop Committees; (8) appoint a representative from each side of the council to sit with the Board of Directors when reports from the council are being considered.

No Workshop Committee or Central Works Council should have any power to impose restrictions on the employers or workpeople either with regard to lock-outs or strikes, or to institute any system of profit-sharing or co-partnership. The council must not interfere with recognised Trade Union practices nor deal with matters covered by agreements, except with the approval of all parties concerned. It should, however, be competent for the Central Works Council to consider matters not here covered, and report the result of its deliberations to the Local District Board.

The Local District Board.-'The experience gained during the past twenty years in the engineering trade warrants the confidence that many feel in this proposal. Under the operation of the various provisions for avoiding disputes, a new type of local official has been developed. 
I think no cmployer or representative trade unionist will find fault with my conclusions on this matter. The measure of local autonomy granted under the constitution of some Trade Unions, and the opportunity for its development afforded by local interviews and local conferences, have brought out, in a wonderful way, a local official of a very able and responsible type. Many, if not all, of these local men are capable of high office, which the proposals here outlined should quickly prove to any who doubt the capacity of the man or the efficacy of the proposed method. Men reared in a cave necessarily take time to become used to the sunlight, but, apart from some initial inevitable failures, I am ready to stake what small reputation I may possess that here lies the avenue along which we must travel to progress.

We will proceed, then, to consider the constitution and functions of Local District Boards. The members should consist of an equal number of employers and workpeople appointed by the local Employers Association and by the Trade Unions in the district concerned. Each side should appoint a chairman and secretary. At local conferences each chairman should preside, and present the case for his own side. Each side should be entitled to hold a preliminary meeting separately co consider and prepare its agenda, and to discuss its policy on questions to be submitted to the local conference. The agenda of each side should be forwarled to the other at least seven days before the holding of the local conference. Conferences should be held at least fortnightly, and the following matters should be within its competence:-(1) References from any Works Committee or Central Works Council, or from either side of the same, within its area; (2) codification, unification, and amendment of working rules relating to holidays, Sunday labour, orertime, shift systems, 
demarcation between classes of labour as distinct from trades; (3) co-ordination of local workshop practice; (4) general district matters relating to welfare work; (5) discussion by mutual consent and reference matters covered by existing agreements; (6) discussion of relations between both sides not covered by existing agreements. In the period succeeding the war the committee should also have their terms of reference widened to cover:(1) Questions arising out of the restoration of Trade Union conditions, including questions of priority of employment, and the restoration of Trade Union rules and customs; (2) the problems of the employment and remuneration of disabled soldiers and sailors ; (3) questions relating to demobilisation and the discharge and reemployment of emergency war workers.

The board should take no action that contravenes any agreement between employers and the Trade Unions whether such agreement be local or national in character. It should, however, be competent for, or be the duty of, all Local District Boards to make representations on any matter to the National Industrial Council.

The National Industrial Council.-Before dealing with this suggested body, it may be wise to ask ourselves if an answer can be found to some of the questions asked at the beginning of this chapter. Is Capital ready to agree to this proposal, and if so, is Capital prepared to treat the matter as a link in an endless chain? Has the point of view of Capital been sufficiently remodelled to attempt to secure co-operation by the granting of a real measure of workshop control? Unless we go forward on that assurance, it is of little value proceeding with this proposal. A superstructure with no foundation is impossible.

If Capital is prepared to give the scheme a fair trial, greater productivity must result from the new harmonious 
relationships. How is the increase in wealth that will result to be distributed? Has the mind of Labour lessened its opposition to schemes of profit-sharing and co-partnership? I believe not! But we will discuss this aspect of the problem at greater length at the close of this chapter.

Will the new machinery lessen the desire for some form of compulsory arbitration on the part of the politician or render its operation unnecessary? I think, in regard to wages questions, there is a definite alteration of angle in the point of view of the employer. I think he would be glad to get rid of the eternal question in industry by agreeing to a periodical reconsideration of wage rates probably with regard to the following:(1) Increase or decrease in the cost of living; (2) increased output; (3) market rates for the commodity produced; (4) state of trade; (5) depreciation of the value of gold in its relationship to the value of commodities. The employer would probably be prepared to accept a sliding scale on some sound basis. But what of the trade unionist? I think whole sections would agree to rule out of the area of possible conflict all questions relating to time wages! But again, whole sections would not! I think the State must function here, and it is probably the least difficult field of all for the superimposition of control from without. But, having dealt with wages, let the State go easy! Neither Capital nor Labour will consent to technical trade questions being taken out of the hands of the parties directly concerned.

Undoubtedly the existing chaos must go on unless the National Scheme in some form such as is here outlined is adopted. The State should give the national assemblies a real standing and authority, though its 
recognition need not be expressed in legislation except perhaps of a permissive character.

The National Industrial Council, when set up, should be representative of the central executive authority of the employers and 'Trade Unions concerned. The representation should be equal, each side having the right to appoint a chairman and secretary, or possibly, in some cases, both parties would prefer that the Ministry of Labour should officiate. Each side should be entitled to hold a preliminary meeting to discuss its policy on the agenda to be submitted. At all meetings of the council the chairman should preside, each over his own side, and present the case for his party. Each side should be entitled to hold a preliminary meeting separately to consider and prepare its agenda, and to discuss its policy on questions to be submitted to the council. The agenda of each side should be forwarded to the other at least fourteen days before the holding of the council meeting, and the council should meet at least once in erery month. When conferences were held in accordance with the provisions of clauses 6,7 and 8 beneath, the council should appoint a chairman to preside ad hoc.

The functions of the National Councils should be as follow:-(1) To deal with appeals from the Local District Boards or from either panel comprising such Boards in the industry; (2) to initiate discussions on relations between employers and workpeople not covered by existing agreements ; (3) to arrange for the submitting of any new agreements arrived at to their several constituents for concurrence thereon; (4) to act as a permanent advisory council to the Government on all matters affecting the industry, and to be empowered to suggest alterations, modifications, or additions to existing statutes; (5) to initiate discussions on fresh enactments 
needed to meet the requirements of the department of trade concerned, and consider proposals for new legislation or amendments proposed to existing laws, which should be submitted to the Government department of trade in control; (6) to hold joint meetings with such departments for the discussion of proposals so made; (7) to appeal direct to the Cabinet-in the event of the Government Department refusing to accept in whole or in part such proposals-stating its reasons for tabling such proposals, the Government Department similarly to be given an equal right. (8) The Cabinet should be invited to meet the parties-or to appoint representatives for this purpose -for full discussion on disputed points; and (9) in the event of a continued failure to reach an agreed settlement the Cabinet should, before exercising its right of veto, submit the proposals to Parliament for a vote thereon.

A few words may now be said of the bearing of these proposals on the strike weapon. Here we touch on the basic problem. The eternal search for freedom of the human spirit has its roots, not only in the foundations of each industry, but of society itself. The use of the strike weapon ministers to a permanent and deep-seated emotion of the human heart, and is in keeping with those tribal instincts which in the past have been the only guarantee of human progress and high endeavour. It is uscless to denounce it as anti-social and barbarous when the mass mind teaches that it bears an ethical relationship to those non-logical and non-analytical modes of thought and action which have brought humanity to its present stage of incomplete perfection. The soul-destroying monotony of the workshop, the absence of opportunity for levelopment, the exercise of the mercly mechanical attributes of the mind-all contribute to a state wherein the protest, aided maybe by the 
love of adventure, seems to afford the only possible outlet for potential energy.

From this point of view, the strike weapon is an ethical force. By no repressive means whatever can it be suppressed. And we ask :-Can this vast reservoir of potential energy be utilised for social purposes? Can the harness of society be stretched to cover and make the parties members of a team? Can the power of the lightning be centralised through the dynamo for the use of society, instead of its destruction?

Let us not make a cult of war, and then blame the workers for its use in apparently anti-social directions! Industry is based on an unequal foundation. As at present run, it will always be productive of internal schism and strife, and be open to interruptions of an apparently disastrous character. Alter its basis, reconstruct its methods, democratise it in all its forms, and leave the rest to take care of itself. The human soul which fails to register its protest against fundamental injustice is already lost. It is already marching back to slaveryindeed, it is already a physical and a mental hanger-on. Give the men a chance! Industry is doomed if we do not, and the menace cannot be greater if we do!

Yesterday strikes took place for the recognition of the Trade Union; to-morrow the demand will be for the control of the industry. Can the avalanche be forestalled? Who are to act as guides to the nation? Are we going to sleep on and wait for disaster, or are we going to consciously strive to build a bridge between this stage and the next? During this present great national crisis, the failure to conscript wealth, whilst robbing Labour of its freedom, offers small guarantee that the State will be braver, or find support in the adoption of a more enlightened industrial policy; and 
this being the fact, it is hardly wise to express the opinion that we feel safe and confident in calling upon the State to move, and move quickly. But, because there is no time like the present to those who want to get things done, we will speak of our hopes rather than of our convictions in this matter.

No work of a more important character can occupy the Ministry of Labour! Let us look to the permanent qualities of the 'Trade Union spirit on the part of both Capital and Labour as our assurance for the coming time. But get the parties together, and, having got them together, do not ask Labour to be content with sops. In order to gain much, much must first be given. Labour will answer the call; it will be ready to make full use of this new power which is coming to it. Give men who desire to be free the chance to become free; exercise patience, and then judge by results.

It is impossible, I think, to over-emphasise the urgent need for securing and establishing industrial peace on a permanent basis, and for doing it now. Give the proposals here outlined a real chance, and whatever else we do let us insist on the State putting the starting lever over.

Finally, a few of the results may be looked at. The greatest and most lasting result would be to provide the missing link in industry. 'The lynch pin of the car of co-operation which to-day holds its place with the utmost difficulty need give us no further anxiety. Harmony in the factory, workshop, and mine, by abolishing the spirit of mistrust and antagonism and guaranteeing continuity of labour, would secure greater productivity. By giving the worker a chance to achieve responsibility, it would bring about a real community of interest between him and his employer. 'The co-ordination of the whole 
factory system would be assured. The progressive development of industry, qua industry, must proceed until the nation is ready to work as a family.

Some of the practical results which seem to me to be immediately likely are:-Fewer hours of labour; longer or more frequent holidays; disbursement on welfare, clubs, institutes, baths, etc.; and a fund for dealing with the unemployed problem in each industrythe place of the Trade Union in relation to this should be referred to the National Industrial Council.

If the distribution of the benefit took any, or all, of the above forms, it would have to be considered whether it should be confined to the works, or extended to the locality. Should the National Industrial Council be the controlling agency? Should one of its functions be the control of educational facilities within its own borders? If confined to the works, what is to be the super-authority? If extended to the locality, is the local rating authority to be called in? If extended to the industry, what is to be the function of the State? What part is the new Ministry of Labour to be called upon to play?

Apart from all material benefits, whether distributed through the employer, the Trade Union, or the State, whether disbursed on an individual or a social basis, whether in actual increases in the pay-box, or in advantages which all can enjoy collectively, I attach the profoundest importance to the consequent permanent raising of the status of Labour. And the bridge having been built which will separate the old order from the new, he would be reckless indeed who would dare to (ircumscribe the individual and social possibilities which the new situation will open up. 



\section{VIII}

By Sir HUGH BELL, Bart.

Anong the multitude of problems which will call for solution when the war ends, none is more difficult-nor, perhaps, more fundamental-than the questions involved in determining the division of the product of industry. It must not be supposed that the problem is new or has arisen in consequence of the war. It would be truer to say that the solution has only been postponed. The conditions imposed by the war have only made it more urgent to find a solution, and this circumstance has enhanced the difficulties to be overcome.

In the spring of 1914 the trade outlook of the world was by no means reassuring. I happened to be in New York, and, at a luncheon given in my honour, had the opportunity of meeting and conversing with some of the chief financial and commercial personages of the United States. They all expressed themselves in grave terms as to the future. The commercial situation bristled with dangerous symptoms, and these were aggravated by the alarm felt on all hands as to the attitude of labour.

'The power of the world to meet the demands on it in various directions was doubted. There were those present who thought we might be on the verge of very serious 
convulsions, and indeed, I was fain to admit there were many grounds for these feelings of anxiety. For a variety of reasons, some of which are dealt with in the course of this essay, there was deep-seated discontent among the great mass of the working classes.

Not very long before, we in Great Britain had experienced this, as illustrated by two great strikes full of significance-the Railway Strike in 1910 and the Coal Strike in 1912. In neither of these cases were the questions raised handled in a manner to bring home to the strikers the gravity of the situation. Rather were they treated in an empiric fashion, which applied a remedy, not to the disease, but merely to the symptoms.

In the case of the railways, compulsion was put on the majority of the companies to do what one railway at least had long ago done.voluntarily-namely, to recognise the men's Union. But it was done in a way which deprived the concession of all grace, and left the men with the feeling that almost any demand, sufficiently insisted on, could be extorted from their employers.

The coal strike was brought about by the demand, on the part of the men, for the redress of certain grievances as to the rates of wages paid under exceptionally unfavourable conditions. The men asked for a guaranteed minimum wage. It ended in much the same way as the railway strike, except that actual legislation was needed to effect the; wishes of the men.

This was in effect only applying to wages the legislative compulsion which had already been applied to hours. In 1908, a legislative eight-hours' day had been granted those engaged in the coal-mining industry. This was indeed sinning against light, for it had been demonstrated that, given reasonable workmen and reasonable employers, a satisfactory arrangement for the shorten- 
ing of hours could be effected by negotiation between the parties.

In the two north eastern counties of England a gradual shortening of hours had been brought about in this way. When the Mining Federation began to agitate for legislation on the subject, the miners of Northumberland and Durham for some time refused to join, and only reluctantly threw in their lot with their less fortunate comrades in other districts.

That legislation was not necessary to bring about such changes can be shown by another even more striking instance. Until 1897, at the Cleveland blast furnaces, which work continuously night and day for seven days a week, the men stood twelve-hour shifts, with the further disadvantage that, in order that the same set of men need not always work on the night shift, a "long turn" of twenty-four hours was worked by one half the men employed on Sunday. By patience and prolonged negotiation, in which the circumstances were carefully discussed between the parties, an arrangement was come to, and now the day is divided into three shifts of eight hours with a long turn of sixteen hours, which comes round to each man once in three weeks.

That blundering instrument, an Act of Parliament, cannot deal with all the varieties of condition from locality to locality. The laying down of hard-and-fast rules inevitably produces at least as many evils as it seeks to remove, and very often only succeeds in exacerbating those which it purports to remove.

I have shown the existence of the unrest to which I have referred by illustrations drawn from my own experience in this country. My hearers at the Railroad Club at Ncw York could give similar instances taken from theirs in the United States. At the time of which I speak, the 
litigation against the trusts in that country was in progress. The various laws passed to prevent these great commercial corporations exercising their powers to the detriment of the community, were thought to have proved inefficacious. Suits against some of them, notably against the United States Steel Corporation, were before the Courts. These were symptomatic of another form of discontent. But signs like those $I$ have named in England were not wanting. The discontent of the railwaymen was notorious, and led to the intervention of the President a year or so later, under circumstances which caused his action to be very adversely criticised. It would not be difficult to give instances from other countries, but I have said enough to recall to the minds of my readers that all was not well in the first half of 1914 .

In New York I was bold enough, in spite of all these protests, to take an optimistic view of the future. My opinion was based on two considerations, on which I think we may safely rely. 'The first is that if we would only be reasonable there is trade enough to go round, and the second is that it does not pay to rob a man, because you can only do it once.

As to the first, without embarking on a long digression, it is, I think, evident that the total activities of man, regarded as an economic producing animal, are the measure of his ability to exchange with his fellow man.

Each individual in the community imperatively demands a certain irreducible minimum to support a bare existence. In order to maintain life, he needs a certain quantity of food and of protection from the influences of the weather. If I may express it tersely, he has a belly to be filled and a back to be clothed. The first clamours for food at least two or three times a day; the scond for coverings which must be renewed at con- 
siderably longer intervals. Without the satisfaction of these primordial needs he will more or less rapidly cease to exist. But this is not all. He must be able to maintain not only himself, but at least three or perhaps four other persons for a considerable fraction of their existence. A wife and a minimum of two children must be kept in health until the latter, in their turn, take up the duties incumbent on them, if the world is to continue on the lines which have existed since man began to live under the circumstances which seem to have prevailed for untold ages. If economic progress is to take place, something more than this is needed. The population will increase as it has increased. Each generation will be more numerous than its predecessor. It will call for the means of subsistence. This signifies that there must be some excess beyond the minimum requirements of what we may call the "social unit," namely, the man, the woman, and their progeny.

Long before the dawn of history, the social unit had ceased to be self-sufficing. A surplus in some directions was produced, which served to obtain the satisfaction of wants which the social unit, by its unaided efforts, failed to procure. Apply this reasoning on the large scale of internal trade, or the still larger scale of international trade, and it seems clear that there must be trade enough to go round. It may be that some unit will produce temporarily too much of some article. But we may safely affirm that never have all the conceivable desires of the world been satisfied. All, therefore, that has been needed has been to direct energies which were otherwise fruitlessly exerted into other channels. 'This has been effected chiefly in an automatic fashion. From time to time men have interfered with this automatic action. States have sought to be self-contained, and 
have forbidden the export or the import of certain commodities. .Various reasons have been assigned for this course. On the one hand, the export of some commodity was deemed to deprive the exporting country of an essential article. For long periods the possession of gold was regarded as essential, and means were taken to prevent its export, but there is hardly any commodity which has not at some time been made the subject of an embargo. On the other hand, for various (frequently contradictory) reasons, the import of certain things has been prohibited or restricted. It has been affirmed that the manufacture of such and such a substance was essential to the wellbeing of the community. To effect this, obstacles rising in importance up to actual prohibition have been interposed between the unit abroad, which had it in excess, and the unit at home, which was deficient in it, but had some other product in superfluity. An exhaustive examination would probably demonstrate that the prohibition was sought to be imposed by some one who produced the article and desired to compel the consumer to take it rather than some other similar article better suited (as he thought) to his needs than the native production. 'The vendor failed to see that what he was really doing was depriving the buyer of part of his surplus, and that if he could not do as well as the stranger he had better turn his energies into some other direction.

There have been times when the jealousies which gave rise to this conduct operated to confine trade not only to the country, but cren to the town affected. In fact, it may perhaps be contended that this is still to some extent true. It is not unhcard of that a Town Council decides that a particular order shall be giren to a manufacturer in the town rather than at a cheaper rate to someone carrying on business at a distance. 
All such conduct is based on the idea that there is not trade enough to go round. I have endeavoured very briefly to show why this is mistaken.

The second reason for confidence in the future is based on the assumption that what may be called the predatory theory of trade will gradually lose ground. The spirit which lined the banks of the Rhine with the castles of robber barons is far from being extinct, either in Germany or elsewhere. Commerce is regarded by many as conflict, and our terminology encourages the belief. But it is not true. Commerce-the economic intercourse of man with his fellows-is not conflict, but co-operation. I rely on the common sense of mankind coming to recognise this fact. When this happens we shall no longer find the present unfortunate attitude prevailing. The international interchange of commodities will be unhampered by tariffs. Services now rendered grudgingly will be performed heartily on both sides. Employers and employed will see that their interests are common, and each will seek to get the best result for the common good, and will be ready to discuss the division between them in a broad and generous way, and not in the haggling spirit which at present too often marks the negotiation between the parties.

If a man or a nation is deprived of the results of the exertion put forth, all incentive to continue endeavours disappears. The certainty that the tax-collector will deprive a man of all benefit from his surplus tends to keep him at the lowest stage at which the primordial needs which have been mentioned are just barely satisfied. Ve can point to a striking example of this view.

Till this country, as represented by Lord Cromer and his coadjutors, took in hand the administration of Egypt, the valley of the Nile showed the effects of the robbery of 
a people by its government. The results of honest rule proved that, even from their own sordid point of view, the Khedives would have done better to abandon plunder for upright management, and would thus have derived larger revenues from their subjects.

We may hope that the world is about to see another illustration of the truth of this opinion. Mesopotamia may, within the lives of men now living, be transformed as has been the valley of the Nile. 'The land through which run the Tigris and the Euphrates may bear a thriving and contented population, contributing by their prosperity to the prosperity of Europe, as has never been the case sinee the time when the great cities which once existed on their banks fell into heaps of mouldering ruins. The nomad Arab, seeking to hide his poor possessions from the Turkish tax-collector, may be transformed into a prosperous eitizen, rejoicing in his well-being, and contributing by it to that of thousands, where now scores, or at most hundreds, pick up a scanty living. What is true of what I may call the molar scale of nation to nation is also true on the molecular scale of man to man.

It is the purpose of this essay to see in what way we can apply, to the workman and his employer, rules which are applicable to the larger groups of mankind gathered into nations. The task has not been lightened by what has taken place in this country in the last three years.

'The state of matters to which I have thus briefly adverted had been brought about chiefly by the inability of the parties concerned to acknowledge the truth of the propositions just advanced. Neither party seemed capable of appreciating the point of view of the other. It is only fair to add that the arguments advanced by each tended to the still further obscuring of the issue. Let us endeavour to appreciate the standpoints of the contract- 
ing parties, and then let us consider the interest of the whole community.

The employer has embarked his capital in some costly enterprise-say a mine or a steel works, or both. He has placed at hazard large sums of money, and he desires to see an adequate return on his investment and a suitable reward for the risks he has run, for nowadays such an undertaking calls for very large sums. He may be opening a new mining district whose uncertainties, always considerable, are much increased by the lack of knowledge gained by similar winnings elsewhere in the district. In any case he has to find the money needed, and to wait, it may be for years, before he sees any return at all.

I am interested in a colliery undertaking in the county of Durham, where many of the incidental drawbacks to which $I$ have alluded did not exist. We began operations in 1897. It took us about three years to satisfy ourselves that we had a property in which we could conscientiously ask our friends and the public to invest the money needed to win the coal. We invited subscriptions, and began sinking the pits early in 1900 . Not till 1907 were the shareholders rewarded by getting any return on their investment. In the period since the formation of the company till the goal was reached, nearly three-quarters of a million of money had been found and expended. Much the greater part of this sum had been spent, directly or indirectly, on labour, so that one of the two parties whose position we are considering had got nothing, while the other had received all they could obtain by means of a very complete organisation which enables them to bargain on fairly equal terms with their employers.

But after this long period of anxious and patient waiting, the pits began to yield a return to those to 
whose foresight and patience their existence is due. Coal began to be worked and marketed. It is interesting to inquire what part of the proceeds remain to whom this result is due. It will come as a great surprise to many who have not studied the question, that not 10 per cent. is left after all the charges of getting the coal are met. Still more will it astonish persons unfamiliar with the coal trade to be told that about three-quarters of the total proceeds go to pay wages and salaries.

I published ${ }^{1}$ many years ago a careful analysis of the cost of making pig iron. 'To make this analysis necessitated examining very minutely the items which go to the cost of coal, coke, ironstone, railway dues, rates and taxes, etc., etc. The result of my examination satisfied me that, in the manufacture of pig iron, beginning with the raw material (the fuel and the ore) and ending with the pig, as near as maybe 70 per cent. of the payments went to labour directly and indirectly employed, something like 5 per cent. went to salaries, and, after meeting all the other charges, not more than 10 per cent. remained to the manufacturers.

Since 1894, I have verified ny conclusions as to pig iron by comparing my figures with those of other industries of a very varied kind. The result has been to confirm my conclusion that, if over a series of years the wages bill had been 10 per cent. higher, there would have been no divisible profit for those to whose enterprise the industry owed its origin. I affirm further, that experience shows that no industrial enterprise can divide amongst its shareholders anything like the whole of the gross profits. I contend, moreover, that this is in the interest of all those who are dependent on the continued prosperity of the business. 'The portion of the profit which is not National Review", February 1894. 
divided remains in the business and is used to maintain it in an efficient condition.

We hear a great deal about the scrapping of obsolete plant. Whence (is it supposed) come the funds to effect this process? They cannot come from new capital invested. If they did, it would mean that the capital account would be swollen by the new money brought in, while that which represented the old machinery still stood in the balance-sheet.

It is obvious that, before an old and worn engine, rendered obsolete by the progress of invention, is replaced by a new and better instrument, it must, during its period of usefulness, have provided the funds to replace it. I hope to show that this principle is even more farreaching than may at first blush seem to be the case. The man-power needs renewing just as much as-perhaps even more than-the machine. It will be necessary to show how this, too, can be done out of the product of the combination.

Since I wrote my paper in 1894, an examination has been made of a more far-reaching character than any which a single individual could undertake.

The Cenisus of Production of 1907 attempts to do for the greater part of the industrial activities of the United Kingdom what I then attempted for my own share in them. It is much to be regretted that the second census which it was proposed to make for the year 1912 was not completed. The preliminary figures had been obtained. Some work was accomplished when the outbreak of war necessitated its being suspended. 'The second census would have been of infinitely greater value than the first. The knowledge gained in collecting the figures for 1907 rendered the materials collected for 191.2 much more precise. The interpretation to be placed on them would 
unquestionably have been more complete in consequence of the much better information gained by the compilers in the course of producing the first report. Had it been possible, preparations for a third census would now be going on, which in its turn would have been of still greater value than either of its predecessors.

The result obtained from the figures of 1907 confirms the general conclusions at which I arrived, that there is no fund out of which it would be possible greatly to increase the share of any of the participants. Any attempt to do this as to the chief of these, namely, the men and women earning wages, must result in failure and may produce disaster.

If this conclusion were final, and were taken to signify that there are no improvements possible on what has existed in the past, it would be a sad lookout for the future. But this is obviously not the case. Let anyone whose experience in these matters extends over a long period recall what existed in his carly days and what now prevails. When I first became concerned with these questions, the wages of the common labour in ironworks were as low as 1 s. 9 d. a day. Half a crown was a good wage, and 3 s. was regarded as a maximum which could, with great difficulty, be reached. To-day, 3s. a day is much less than some people regard as the minimum wage which ought, in their judgment, to be imposed by law. It may remain in the pay-book, but it is then merely the "base rate" to which a percentage has to be added. In certain industries this addition exceeds 100 per cent., a figure arriced at by protracted negotiations, ending in a compromise which the workmen are inclined to regard as depriving them of their fair proportion, and the employers assert to be beyond their capacity to pay. It must be admitted that the changes in value produced 
by the war are responsible for some part of this rise. Not without a show of justice is it contended that the $6 \mathrm{~s}$. or $7 \mathrm{~s}$. a day now paid, hardly places the recipient in as good a position as half the amount would have done at some earlier date.

But it is not with the exceptional situation created by the war that I wish to deal. My endeavour is to consider the position from the more general standpoint, excluding, as far as may be, the accidents which at the moment affect us.

From this general standpoint it may be affirmed that, excluding the war period and also, for other reasons, a few years prior to August 1914, there has been a steady increase in the rates of wages. This has been accompanied by a very marked rise in the standard of life. Let anyone familiar with the subject consider the sort of workman's cottages which were provided by the colliery owners in Northumberland and Durham, say in 1850, of which, by exception, some still exist, and compare it with the house built fifty years later, and he cannot fail to be struck with the contrast. And it is not only the house which has improved; all the surroundings are, beyond measure, better. The school (if school existed) was a hovel compared with the school of to-day, and it is now provided gratuitously (as it is ironically called). The sanitation, though still by no means ideal, is infinitely better, if, indeed, a comparison can be instituted between a non-existent thing and something (however poor) which does make a show of performing the service for which it was devised. All these improvements cost money. They add to the amenities of life, and they raise the standard. They are provided out of rates or taxes, or both. And the ton of coal pays this charge as it pays all other costs of getting. 
We are thus brought to consider the vital propositions which affect this case. It seems a mere truism to sar that the unit of production, be it the ton or the yard, bears the whole cost. The coal-owner or the mill-owner has no bottomless purse out of which to find all these things. The merchanted ton must pay for all. If I insist on this fact, it is because it is apt to receive nothing but lip service from many who deal with these matters. Free education is belauded as a great gift to the people. But the costly schools, the services of the trained staff, the equipment of books and apparatus, are not provided gratuitously. The rating authority or the imperial exchequer has no funds but what have been gathered from the proceeds of the article of manufacture. If you double my rates and my taxes by so much you lessen my ability to pay wages. And in so far as the expenditure incurred benefits the men in my employment and their families, in just as far the cost of these benefits must be regarded as part of wages. But whether they benefit or not, the only source from which they can be defrayed is the income produced by the sale of the commodity. If a claim is made for this or that-old age pensions, or compensation for accidentit is met by withdrawing some part of the proceeds from some other use.

To whatever advance in actual money wages, we must therefore add something considerable in regard to these various advantages which have accrued to the wageearner. Until some years before the war, there fell to be added also no unimportant amount owing to the cheapening of all articles of consumption. 'The rise from 1 s. 9 d. to $2 \mathrm{~s}$. in the labourer's wage represents by itself an increase of 70 per cent. It does not seem unreasonable to say that the increased purchasing power 
of the 1s., and the various amenities thrown in, make the actual position of this wage-earner at least twice as good in 1900 as it was in 1850 .

Whence has this great improvement come? The answer is that the man has been much more efficient. That what was done by man-power, is now done by a man handling a machine. The labour cost at the Cleveland Blast-furnaces when they came into existence about 1855 amounted to about 6s. a ton. When the war broke out it had fallen to about half that amount. And yet every man employed was paid nearly double the sum obtained by his predecessor, two generations earlier. An uninterrupted series of improvements had been effected to ease the labour of the workman and render it more efficient. This has becn done in the face of continued resistance by the men. When we come to consider their standpoint, we shall see that they had at least a plausible justification for their attitude.

The great expenditure now going on in this country on works of which the first purpose is to provide means of carrying on the war, but which, when peace comes, will have to dispose of their output in the open market, involves a different division of the produce of such works from what has been hitherto customary. I have shown that of the gross income of certain businesses, about 10 per cent. is all that remains to remunerate the capital engaged. Suppose the amount of capital per ton is doubled, it is clear that a larger proportion is needed to afford an adequate return.

In this country the capital engaged in the iron trade is turned over about once a year. 'Ten per cent. on the gross income would mean the same percentage on the capital. If you double the capital, that same 10 per cent. on the income would only yield 5 per cent. on the 
larger capital. But if capital camnot be attracted for a less return than heretofore, you must be able to retain not $£ 10$ for $£ 100$ of income, but $£ 20$. To obtain this, economy must be practised somewhere. The obvious item for attack is the Lábour Bill. It is, as we have seen, much the largest, and it is the only one over which the owner of the works has control. The process to be followed is equally obvious. The additional expenditure consists, I will suppose, in some more effective implement which replaces one needing more men to work it. 'The staff required must be reduced in number. This is a matter with which, from another aspect, the men are deeply concerned. They see that some of their number will no longer be required, and though they also see that a higher wage may be payable to those that remain, they hesitate to accept a change which will involve some of them losing employment. It will be necessary to revert to this matter when we come to consider the workman's point of view. Enough has been said to show the difficulty with which the employer is confronted.

The relatively small return to the ironmaster or the coal-owner will have to be increased to meet the increased demand of the capital involved. 'The difficulty with which we shall have to deal will not be lessened by this increased demand on the part of Capital. It is necessary to prepare the public for what is likely to happen when the war is over, and the costly works now built or building have to justify themselves by affording an adequate return to those interested in them.

Let it not be supposed that this is a matter of indifference to the country at large, still less to the workmen engaged in any particular industry. If the population continues to increase in the future as in 
the past, it is necessary every year to provide capital to find work for those of the inhabitants who have become ready for employment. In the past, the increase has been approximately at the rate of 1 per cent. per annum. That means that for every 1000 men in my employment, some ten or so will each year reach the stage of wanting work. To set a man to work in the works in which I am interested, needs from $£ 150$ to $£ 200$. Consequently $£ 1500$ to $£ 2000$ must be found if employment is to be given to the sons of each 1000 men who are working for my firm. If we do not see our way to getting a reasonable return, we shall not be able to do this, and the young men must go elsewhere. What is true of us is true of all others in like case. This means that the young men will have to go away and find employment elsewhere-in some foreign country or in one of the dependencies of Great Britain. We need not shrink from the alternative, but it is no use pretending it does not exist. It must be faced and dealt with. There is no insuperable difficulty, but it will need great skill and patience to bring about a solution which shall maintain Great Britain in the position she occupied before the war.

Before we leave this subject altogether, it may be well to examine another industry which differs from iron and coal in respect to the rapidity of turnover.

'The railways of the kingdom give an excellent and very remarkable illustration. There the turnover, instead of taking place in twelve months, extends over nearly nine years. The gross income for 1914 amounted to just over $£ 139$ millions, and the capital expended to slightly over $£ 1341$ millions. After all expenses had been met, about $£ 51$ millions remained for the shareholders; that is to say, instead of only about 10 per cent. being left 
for the shareholders (as in the iron trade), about 36 per cent. was left, and yet the average return on the capital was only about $3 \frac{3}{4}$ per cent. Can anyone pretend that the railway system of Great Britain can be maintained and improved to meet modern needs if a dividend of less than 4 per cent. is all the investor can expect? This consideration has not prevented the men employed on the railway from asking, before the war, for increases of wages which would have gone far to sweep away all the dividend of the ordinary shareholder, and to place the preference shares, or even the debentures, in the position of being very doubtful investments.

'The whole of the 23,441 miles of British railways have been taken to give these figures. The railways gave employment to 608,750 persons. I think I shall be within the mark if I place their wages bill at from $\mathfrak{f 5 0}$ to $\mathfrak{£} 55$ millions a year. An increase of 10 per cent. on the wages means from $£ 5$ to $£ 5 \frac{1}{2}$ millions more payable by the ordinary shareholders. 'They represent on the average approximately a third of the capital enbarked in railway enterprise. On this third must fall the whole of any advance until the surplus, after mecting debenture interest and preference dividend, has disappeared. Suppose (as is not far from the truth) that it took, before the war, about one-third of the surplus, about $£ 17$ millions would go to it, and it follows that 10 per cent. increase of wages would mean nearly one-third less dividend.

The subject is so interesting and important that it warrants some further and more detailed examination. 'To take the whole of the railway enterprise may be thought to obscure the issue by taking some very unremunerative railways, which ought never to have been built in the way in which they were. Let us take a large prosperous and progressive company for this further 
examination, and, to avoid the disturbance caused by the war, we will take 1913 instead of 1914, the year of which we have been considering the figures.

In 1913 the North Eastern Railway Company, with nearly 1800 miles of road open for traffic (say 8 per cent. of the whole of the railway system of the kingdom), had a capital of $£ 85$ millions in round figures. The gross income was $£ 12 \frac{1}{2}$ millions, the expenditure $£ 8$ millions, and there was a balance of $£ 4 \frac{1}{2}$ millions. The capital was turned over in something under seven years. There would have been needed $£ 4 \frac{1}{2}$ millions to pay 5 per cent. on the total capital spent. 'The wages paid in that year came to $\mathfrak{1} 4 \frac{1}{3}$ millions, and were distributed among nearly 53,000 persons of various sorts-each on the average thus

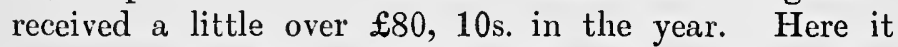
becomes necessary to distinguish between the various classes into which the persons employed on the railway are divided and subdivided.

'The 53,000 men employed consist not only of those belonging to the operative class-those whose income, on the whole, may be takel to fall below the income tax level-but also, first, the clerical staff; next, all those concerned with administration ; and, finally, those to whom the superior control of the company's affairs is entrusted. Taken altogether, these three classes comprise upwards of 8000 persons. Very much the greater part occupy subordinate positions, and receive relatively small pay. They occupy an important position in the railway hierarchy, and constitute, in some sort, the subordinate nerves by which the central brain, of which I am about to speak, communicates with the periphery.

I now come to the real motive force of the undertaking, which, to continue my simile, may be compared to the great ganglia and brain of the higher living 
organisms. To this small group of persons, barely $\frac{1}{8}$ th per cent. of the whole army of the 53,000 persons, is confided all the important duties of general direction and superior management.

It is sometimes said that the product of industry is given in too large a proportion to the highly-paid officials. Let us see how this stands in the case of the railway company. The total amount payable to the higher members of the staff-the ganglia and brain-does not amount to $£ 100,000$, out of a total income of $£ 121$ millions-in fact, much less than ${ }_{3}^{2}$ rds per cent.; while the whole salaried staff does not absorb 7 per cent. of that total. I have usually given this figure as not exceeding 5 per cent. It is greater in the railway service, because certain grades are counted as clerical, which in ordinary industry are called operative. On a true comparison made on precisely the same lines, I incline to the belief that 5 per cent. would cover both sorts of industry.

The whole complex of nerves, ganglia, and brain absorb nearly a million of moncy, but, as the average income of each individual is only a little more than 40 s. a week, it is evident not much can come from this source towards the improvement of the position of the less important but more numerous elements of the organism. Deducting the carnings, and the numbers of these thrce classes, and there remain the operatives, pure and simple, $£ 75$ apiece a year on the average.

Before leaving this subject I would like to call special attention to the small total amount paid for superior management, and the small number of persons in this class. That great skill is needed will not be denied by anyone conversant with the matter. A competent manager is very hard to find, and must be found among 
the small group of officials at the top, numbering considerably less than 100 all told. It may be questioned whether this is enough to give width of choice to the employer, and chance of being chosen to the man who has the root of the matter in him? The qualities needed for a general manager are not easily found combined in one individual. He may be compared to other specialists to whom the public is willing to pay large fees for their services. A clear and rapid judgment of men, great tact, very varied knowledge and experience are called for. A salary of many thousands a year would be well expended on such a man, and the whole service might reap the benefit in better conditions, and even better remuneration consequent on his better administration. It would indeed be penny wisdom which refused to recognise these facts. This is more conspicuously true when it is borne in mind that his whole salary does not claim more than a minute fraction of 1 per cent. on the earnings of the company. It is abundantly clear that no serious improvement in the remuneration of the great mass of railwaymen can be got. from any of the three classes into which $I$ have divided the salaried staff.

One other point must be mentioned. It is often said that too many foremen are employed. The men have themselves to thank for this state of things. Foremen and inspectors and such like are employed because experience has unfortunately made it clear that men must be watched or they will not do their work properly. The employer dislikes all expenditure with which he can dispense, and the workmen may rely on it that all such supervision would vanish as soon as it was found to be unnecessary.

The dividends were distributed among upwards of 60,000 holders of ordinary preference shares and deben- 
tures, so, if the whole surplus of $£ 4 \frac{1}{2}$ millions had gone equally, each shareholder would have got a trifle under $£ 73,10$ s. a year. It will be seen that if the men of all sorts got 10 per cent. more, those who found the capital would have had to sacrifice about 11 per cent. of their income.

The ordinary shareholder on the North Eastern Railway is better off than many others, for he has always received a substantial return. But let us see how even he would stand if any great increase in wages were given. We have seen that a balance of $£ 4 \frac{1}{2}$ millions of net revenue remained at the disposal of the proprietors. The debenture and other interest charges and the preference shares absorb nearly $£ 2$ millions, leaving $£ 2 \frac{1}{2}$ millions for the ordinary shareholders. If the workmen got 10 per cent. nore wage the $£ 2 \frac{1}{2}$ nillions will be reduced by as near as maybe 20 per cent., and the dividend will fall on a like proportion. How will it be possible to meet the evergrowing need of the district served by the North Eastern Railway if this fall is to take place?

In a growing district such as the North East of England, the railway is perpetually called on to give additional and greater facilities. Careful consideration has led to the conclusion that an annual capital expenditure somewhere in the region of $£ 1,000,000$ is required for this purpose. The subject is one which occupies a great deal of the attention of railway directors, for it means more capital, and capital must be tempted. How difficult it has been in recent years before the war to get these additional resources, all who are familiar with railway finance know. 'The difficulties have frequently compelled the delay of works which otherwise would have been put in hand. If the return on the investment is reduced, the difficulty will be increased, the growth of the district will 
be checked, employment will fall off, and wages, instead of rising, will decline.

It belongs to another phase of the question we are considering, but it must not be forgotten that, while the men employed on the railway ask for more wages, the persons using the railway are clamouring equally loudly for better and cheaper services. Lower rates of carriage, more rapid despatch, better passenger accommodation and cheaper fares are demanded. Parliament too readily responds to these contradictory demands. Wages are raised by statute, rates and fares are reduced. Railway companies are put under various disabilities and obligations, and are denied the means of meeting them. 'The attitude of mind, for which Ministers of the Crown must bear a share of the blame, makes me almost despair of being able to meet the situation which is likely to arise when at last we return to something like normal conditions, and begin seriously to consider how the expenditure of the last three years is to be met out of the income of the country when the simple method of borrowing to meet it has come to an end.

We have examined two very different kinds of industry. Fortified by the results shown in the Census of Production, we are brought to the conclusion that there is no fund within the control of those engaged in production of any kind from which to give any additional payment to the persons to whom already falls the chief part of the product.

Let us now see the standpoint of these persons. I feel much less competent to deal with this part of my subject. The difficulties encountered by the employer are much more present to my mind than those from which the workinan suffers.

Some indication has already been given of the way in 
which the former meets his economic troubles. 'The greater part of his outgo is paid to the men and women in his employment. A very insignificant reduction in the cost of labour affords great relief. It is, accordingly, the wages bill which is perpetually under consideration. There are two ways in which it can be lessened. Either the labour can be paid at a lower rate per day, or the daily output per man can be increased. On the first blush either alternative offers obvious disadvantages. The first (if it can be applied) is much the simpler. Nothing is needed but the decision to pay $27 \mathrm{~s}$. a week, while up to now 30 s. has been paid. Unfortunately, this easy solution is by no means palatable to the recipient of the 30 s., who desires to have 33s. a week. He makes a very strong case for his demand. He points out how small a residue is left after the essential requirements of what we have called the social unit have been met. The stern argument of driving need alone ccmpels him to accept the disagreeable alternative.

A great fall in the selling price of the article he and his employer are engaged in producing forces him reluctantly to accept a reduction in wage. But this is sometimes not brought about till the very uneconomic process of a strike or lock-out has been tried, and a compromise which could probably have been effected without this is reached.

'The other alternative has also serious drawbacks to the workmen. It works in one of two ways. More work is required for the same pay, and thus the number of persons employed is lessened, or some labour-saving machine is introduced, and a sufficient number of workers are discharged to pay for the machine and still make the cost of the article at least no higher than before. Either alternative is distastcful to the workmen. 
If the parties to the transaction would realise the truth of the proposition, that it is the real interest of all to obtain the largest output, more rapid progress towards a solution might be looked for. But all are too apt to forget where their interests are common, and look only in the directions where they diverge.

Great sympathy, perhaps even admiration, may be felt for the men who decline to accept a solution which involves loss of employment to some comrade. The fact that the loss may fall on any one of them must, indeed, not be disregarded. On both grounds it is easy to see why " improvements" are not welcomed by the workmen whose employment they affect.

There is, moreover, another reason why this is the case. As far as possible, employers like to pay by results. They seek, therefore, to fix the wages of the man by the amount of work he does. 'I'hey also want to produce as cheaply as may be and make consequently so much more profit. From these two propositions emerges an obvious conclusion. They wish to fix the payment as low as possible. 'The workman may admit the truth of the proposition, but he on his side wishes to receive as large a share as possible. If we could establish some measure by which to deternine what is the fair share of the parties, the problem would be a very simple one. But from what has been said in dealing with the division of the cost of production, it will be evident that no percentage can be fixed. The 30 per cent., or thereabouts, of the gross income which represents the share paid to the railwaymen in wages would be quite inapplicable to the ironworker or the coal-miner, who, as we have seen, takes over 70 per cent. To stipulate that the man is entitled to a "fair wage" or a "living wage" is equally out of the question, because it is impossible to come to any agreement as to 
what is meant by the term. The nearest we can come to a definition would seem to be "something more than is being actually paid." This obviously lacks finality, and leaves us very much where we were at the outset.

The wage to be paid lies between two limits which cannot be settled with any great precision. It cannot be lower than the amount on which the recipient can fulfil the conditions imposed on what we have called the social unit. If it is less than this, he will not continue in that calling. It cannot be more than the employer can, taking one time with another, afford to pay and fulfil his duties to the community. These consist in maintaining and improving his works, so that they may continue to provide employment for the population depending on them, not only to-day but in the future.

It is somewhat rashly assumed that the man is not readily able to change his occupation. The war has demonstrated how little foundation there is in this assumption. We have seen with what facility men have turned from their accustomed work to other employment of quite a different kind at the call of their country. Even more remarkable has been the way in which women turned to work which before was thought quite unfitted for them. It was supposed to need skill of a kind of which they were not possessed, and could acquire, if at all, only after long apprenticeship. The women showed the world (what many of us knew) that much too large a part was assigned to the amount of skill and training needed in certain trades.

But other examples of the truth of this can be given. 'T'wo of a very remarkable kind come within my personal knowledge. The soda trade of the Tyne, from being one of the staple industries of that district, languished and became practically extinct in the course of a very short 
time. 'The iron rail trade, up to about 1870 , on which the iron industry of Cleveland very largely depended underwent a like experience by the perfecting of the Bessemer process. It would take me too far to go into further details; the general statements cannot be questioned.

It is true these changes, and especially the latter, which came very suddenly, produced great inconvenience, and indeed suffering. But within a very short time the men who were thrown out of work had found other employment, and the Tyne and the Tees regained their prosperity with astonishing rapidity.

The conclusion to which we come, then, is that the workman need not apprehend any permanent danger from improvements of the character indicated. He and his employer alike ought to have a keener eye, not so much on the rate of wage as on the labour cost of the article produced. If that can be lessened, it may be possible to raise the wage of the men engaged in its production.

'The steady rise in the standard of life, to which at an earlier stage reference was made, is a further proof of this. It has not hindered the reduction of cost. On the contrary, that very reduction has rendered its raising possible. 'Turn where you will and you find the truth of this. Before the introduction of steam the cost of locomotion was a serious bar to the raising of the standard. Men were practically immobilised. The great mass of the people lived and died where they were born. 'The opposition to railways was based by one class of the community on arguments which nowadays we can hardly contemplate. But this class had no monopoly of foolish conservatism. 'The introduction of the power-loom was riotously resisted by the people to whom, in the long run, 
it was to bring the greatest advantage. For it must be remembered that cheapness is more in the interest of the less well-to-do than of the richer members of the community. In different ways we are probably being as stupid and bigoted to-day. The next generation will regard with amazement our resistance to changes which they will see were not only inevitable but beneficial.

Why, then, do such conflicts arise? It is not difficult to answer the question by taking a specific example of what happens. Mine shall be chosen from my own trade and within my own experience. Steel is now made chiefly by what is called the Martin Siemens process. Stated quite briefly, this consists in introducing pig iron -usually already molten-into a furnace so contrived that a very high temperature can be maintained in it. By this process certain ingredients contained in the pig iron are gradually eliminated, and the metal becomes the much less fusible steel. But the high temperature maintains it in the molten state, and after a certain number of hours the furnace is tapped, the steel rum into ingots, which are then converted into the various articles-plates, sheets, rails, girders-for which modern industry calls.

The furnace is very costly to build and to uphold. 'The proprietor desires to get as much steel as possible out of it during its relatively short life. 'The number of men on each shift on whose skill and industry its efficient working depends is very small-three or four perhaps. There are a great many other's whose labours contribute only indirectly to this end. We need not go into any further details for the present purpose, as it is the furnacemen proper whose position and pay we are about to consider.

At first the furnaces were relatively small-10 tons 
or even less being about the capacity. A tonnage rate was fixed at a figure which, at the output of such a furnace, would give what the owner regarded as a tempting wage. But a rapid process of improvement went on, and the 10-ton furnace was found to yield a considerably larger amount of steel. With little or no additional labour or skill on the part of the furnacemen, the wage increased. 'The next type of furnace was bigger and better. It cost a great deal more, and that extra cost could only be made remunerative by reducing the cost of production. A struggle between the owner and the furnacemen resulted, the owner contending that a much lower tonnage rate would give the furnaceman an adequate wage, the man urging that additional tonnage meant additional labour and that no reduction could be accepted. In the end a compromise is effected. A lower tonnage rate is agreed upon. The furnace is again found more productive, still larger furnaces are built, and the process begins all over again. To meet the contention that the handling of larger quantities involves more labour, charging cranes and other labour-saving devices are installed. These require saving in other directions to pay for the interest and redemption of the costly tools and the labour for working them. The saving is got by reducing the tonnage rate, while leaving the furnaceman a tempting wage. The same process is once again gone through, with the same result.

It is not with the object of attributing to the furnaceman any bad faith that it is necessary to dwell on an aspect of the case which presents itself in this as in numberless like instances. When the furnace was first installed, no one could be sure of its output. 'The men were set to work on day's wages, with a view to seeing what could be done towards settling the tonnage rate. 
During this period-and during all the subsequent periods - it was not their apparent and immediate interest to produce the largest quantity possible. They knew that the tonnage rate depended on the experience gained, and "ca" canny" was their not unnatural attitude. Not all the furnaceman's efforts could get out of the furnace more than some as yet undetermined amountbut it was well within his power to prevent an output in excess of what he thought his labour ought to produce.

A struggle between the man and his employer ensued, in which masterly inactivity was the man's obvious policy. But no sooner is the tonnage fixed than his outlook entirely changes. Now he wants to get the last tonsubject to one consideration, that if he gets much too much, probably an attempt may be made to reduce the rate in that furnace, and that, certainly, work on the next and improved furnace will be offered at nuch lower figures. And so he produces, not as much as he can, but as much as he and his mates think may be safely produced without leading to a lowering of tonnage rate. 'The net result of it all is, that rates of wage quite out of proportion to the skill required are paid to men who can by their opposition reduce the output of the implement in their charge.

This is no imaginary sketch, but is based on real experience. The furnaces have been gradually increased in size, till from 20 tons they have grown to produce 40 , 50,60 , or even 100 tons. Nor, as far as can be foreseen, has the limit been yet reached. The wages under the circumstances described have increased, till the three men on each shift who have charge of the furnace are earning wages which rise as high as $£ 14$ and $£ 9$ and $£ 7$ a week respectively. No one will maintain that they have not a laborious, irksons, and responsible job, but that the wage 
they get is out of all proportion to the amount of skill and labour they apply cannot be denied.

Why, it may be asked, does the steelmaker submit to such a state of things? The answer is very significant, and goes a long way to explain a great deal that happens in industry. 'The manufacturer is out for profit. $\mathrm{He}$ is not, as such, a social reformer or a political economist. He very often considers that sort mere theorists and faddists. He has a costly apparatus from which he wants to make as much money as he can. He finds that the men in charge can hinder if they cannot greatly help. He counts on evoking their self-interest on his side. He overpays them. But, when all is said and done, the overpayment is counted in pence per ton, and it is cheaper to waste those pence than, after a great struggle and possibly a severe loss, to find that the Union has been stronger than he, and he has to give in after all. It is true he has created a privileged class among the workmen. I have known, in other industries, endeavours made to secure to the Union the right to nominate to this privileged class. This circumstance alone causes me to doubt whether, even in the Utopia of which some dream, there will be complete abolition of privilege, for here, in the class whence proceed the most vivid denunciations of it, we see it getting a foothold.

Instances without end might be given. One more, from quite another calling, may serve. In Durham, when a new seam of coal is about to be opened in any colliery, the first thing to be done is "to fix the hewing price." The manager selects some group of trusty men to work the new seam. He does his best to see that they do a reasonable day's work for the wage he has agreed to pay them. At the end of a fixed period the results are used to determine the tonnage rate, which is fixed accordingly. 
No one acquainted with human nature will be surprised to learn that no sooner is the tomnage rate fixed than the output per man goes up to an astonishing extent. Care, however, must be taken not to raise it too high, for another rule provides that if the average earnings of the hewers in a given district are above the average wages of hewers generally, a reduction may be sought-and vice versa.

It is worth noting, in passing, that all this is distinctly anti-social in its effects, for it inevitably results in enhancing the cost of working coal. But, speaking generally, this is the result of all the arrangements which have for their object the maintaining of wages above the level to which they would fall under a really equitable system, could such be discovered. 'This, however, belongs rather to a later stage of the subject.

If these facts are borne in mind, we shall see how shortsighted is the conduct of both parties to the bargain which results in the settlement of wages. Each side should aim at the greatest possible amount of production, for the least possible expenditure of effort, and at the lowest possible cost. This need not mean that the remuneration of any of the parties shall be lessened. On the contrary, there is every reason to believe that all will gain in the process. There is no escape from the proposition that this means the employment of a smaller number of men, though these are paid a higher wage. But it does not mean that the men who, by the assumption, are no longer needed in some particular industry will therefore not find employment. They will still possess the primordial needs of which we spoke at the outset, and they will turn to other means of satisfying these. There is plenty of demand for their labour. It is not from abundance, but from scarcity, that the world has suffered in the past, and is likely to suffer in the future. What 
has frequently caused suffering has been the not unnatural desire of each to make his own item of production scarce, and so obtain an enhanced price for it. The policy is essentially selfish, but it is worse than that, for it can be shown to defeat its own object in almost every case.

Before we leave this part of the subject, another side of it must be mentioned. The mistaken policy of preferring scarcity to abundance takes not infrequently this form. The workman seeks to gain his end by losing time. He imagines that, just as surplus production tends to lower prices, shortage will tend to raise them, and if he works less he may thus earn more.

This fallacy takes various forms. We hear, for example, of the man who only works three days a week, believing that in this way he leaves (as he says) a job for another man. He is radically mistaken; he deprives a man of a job. If he had worked he would have earned money. If he had earned money he would have spent it, and, in spending it, would necessarily have found work for someone.

But the effect is more far-reaching than even this. Suppose a man employed in a certain work is paid by the ton and produces five tons instead of ten. All the cost beyond his actual wage falls on the smaller quantity. A specific example will make this clear. It shall be taken from coal-mining.

A pit is fully equipped with machinery of all sorts to produce, say, 1000 tons of coal a day. It stands, ready with all this apparatus, to produce its daily quantity. But, instead of the hewers, etc., needed to get the coal presenting themselves, a certain percentage fails, and those who do come work less coal than they could reasonably produce.

Assume that to produce 1000 tons of coal a day costs 
10,000 pence or $10 \mathrm{~d}$. a ton for all preparatory work to keep the pit running. This preparatory work comprises not only the skilled supervision of all kinds, for which the ton of coal has to pay, but also the actual daily outgo to men attending on pumping and winding engines, all the underground haulage, ventilation, etc. To all this we must add the proportion of interest and redemption for the day, which ought to be divided over the proper output, but which will fall on the lesser quantity. The figure assumed is an arbitrary one, but it is not far from the truth in certain cases. Assume that instead of producing 1000 tons in the day in question only 900 tons are produced. 'The 1000 tenpences which have to be paid whether the pit works full stroke or not fall to be paid out of the 900 tons-that is to say, the $10 \mathrm{~d}$. a ton becomes for that day over 11d. Now that extra penny has to be paid somehow. 'The owner, who is not responsible for the loss, will not pay it if he can help it; and as the workmen are going to receive something over 70 per cent. of the total price of the coal and more than 80 per cent. of its cost, it is most likely that they will be called upon to pay it in whole or part. It is clear, therefore, that the man not only earns less by working less, but his earnings per ton are reduced by the extra cost which his slack working incurs. It is, therefore, quite true to say that his conduct, and that of those who do likewise, actually defeats the object they have in view, and renders the coal-owner less able to meet their demands.

What is true of the miner is at least as true of the factory worker. Take the case of a man in charge of some costly tool-a lathe, for instance. Such a machine costs money to install, to run and maintain, and these constitute first charges upon it, for unless they are met we should not have the tool. The only source from which 
they can be met is the output of the machine. The operative causes the charge per article produced to be greater, then complains that his employer refuses to increase his wages, forgetting that by his own act he has lessened the income of the tool and increased the percentage charge against it.

Let me assume that the tool could produce 240 of the articles which it is designed to manufacture, and that it costs 20s. a day to run. Each article has to bear $1 \mathrm{~d}$. If the restriction placed on output reduces the 240 to 180 , the cost is raised to $1 \frac{1}{3} \mathrm{~d}$. per article. Suppose we put the wage of a competent man working such a machine at $6 \mathrm{~s}$. a day. The labour cost of each article will be $0.3 \mathrm{~d}$., and the tool cost to $1.33 \mathrm{~d}$., together nearly $1 \frac{3}{4} \mathrm{~d}$. against $1.3 \mathrm{~d}$. Now see what would happen if, instead of making 60 less than the proper tale he made 60 more. The labour cost falls to $0.24 \mathrm{~d}$., the tool cost to $0.8 \mathrm{~d}$., and the total for these two amounts to only a trifling fraction more than in the normal conditions the tool cost alone would have come to. If I pursue this dull subject further it is because I wish to found other reasoning on it.

Let nie further assume that the article when finished is worth $2 \mathrm{~d}$. 'The 240 will produce $40 \mathrm{~s}$. at a daily cost for labour and tools of $26 \mathrm{~s}$, and with a balance therefore of $14 \mathrm{~s}$. to meet all other outgoings - the cost of the material, of management and distribution, etc. But if only 180 are produced then the $40 \mathrm{~s}$. falls to $30 \mathrm{~s}$., and there remains only $4 \mathrm{~s}$. to cover all these expenses, while if it rises to 300 we have 50 s. against outgoings of $26 \mathrm{~s}$. as before, or a surplus of $24 \mathrm{~s}$. In practice, what lappens is this:-A new machine is installed; a discussion between the employer and the men's Union takes place as to the rate to be paid for piecework. The two 
parties agree that $6 \mathrm{~s}$. a day is a fair wage for the work. The employer says he thinks the machine should turn out 300 articles in the shift. The men say 150 is the outside possible. In the end 240 is agreed upon, and the rate is fixed at $6 \mathrm{~d}$. a score. We need not consider the endless details and technicalities, the experimental runs, etc., etc., which have been required to get thus far. But, arrived at this point, there is still much more manœurring on both sides. The Union seeks to fix the $6 \mathrm{~d}$. rate, and to do this they compel the workmen not to exceed but rather to fall below the standard of 12 score. The employer, on the other hand, who wants to get his wages cost as low as possible, tries to force the pace, and to show that without any undue effort the men can make two or three score more, and that he ought to do this for the $6 \mathrm{~s}$.

So far I think both are mistaken, but the worse mistake is that of the employer, for see what happens if the man, in fact, makes an extra couple of score. He indeed gets 1s. above his agreed wage, but the tool cost remains constant, so the total cost for those two items comes to $27 \mathrm{~s}$., while the selling value of the output becomes $46 \mathrm{~s} .8 \mathrm{~d}$. Therefore the surplus is $19 \mathrm{~s}$. $8 \mathrm{~d}$. against. $14 \mathrm{~s}$. on the normal output.

The reconciliation of these divergent views is the difficult problem which faces us. If my example were quite a typical case, this ought not to be difficult, but a great many other considerations have to be taken into account.

I will point out one which is of very common occurrence. The employer sees ways of improving the tool. 'l'hese involve increasing the tool cost, and the 20 s. becomes, say, 30s. The effect of this is to enable the man to produce considerably above the agreed normal 
output of 240 , with (as the employer contends) no additional labour to the man. If the improvement produced only a few score more articles, the employer would be repaid for his outlay. But it has too often happened in the past that the men have strenuously opposed changes of the kind-nor can one be altogether surprised at the line they take. The Union supports them, and the improvement is not introduced. Scarcity has been preferred to abundance.

How can these divergent views be reconciled, and the parties induced to come to an amicable settlement? 'This is the problem which in one form or another awaits solution. Strife between those interested will be of no avail. Let us hope that wiser and more temperate counsels will obtain a hearing. Knowledge is what is most needed, and next an ability to see the point of view of the other side.

The establishment of more intimate relations is perhaps of even more urgent importance. It may be doubted whether these can be imposed. They will be more likely to be accepted by both parties if they come from within, and as the result of voluntary agreement between those chiefly concerned. 'The leaders on both sides must co-operate. Above all, the essential limits of the problem must be recognised. There appears to exist too great a tendency to appeal for help from without. The State is asked to intervene to settle questions which would be much better settled by negotiation between the parties.

IVe have seen that State intervention in the past has not produced very good results. It would probably be found very difficult to determine whether the coalminers or the coal-owners are most dissatisfied with the Minimum Wage Act. My own opinion would incline 
to the conclusion that the coal-owner would carry the palm of discontent. But from what has fallen from the representatives of the miners it may be questioned whether they would accept this view.

On another side may be noted the readiness with which appeals for help are addressed to the State. The housing problem is among the most urgent. Legislation of a very hasty and ill-considered kind had, before the war, made the provision of cottages almost impossible, and a great shortage already existed in 1914. Since the war, the rise in cost, the difficulty in getting materials, and, finally, the prohibition of building except by special permission of the Government, have increased the evil. It is said that we are short of cottages to the extent of a million. This may be an exaggeration. But when it is borne in mind that something like 80,000 cottages are needed every year to house the increase of the population, it will be admitted that the number is very large. Demands are made for State aid to provide these. It seems to be thought that the State possesses resources from which any demand can be satisfied. Will men never learn that the State's resources are drawn from their own pockets, and that to get money from the State means that it must first be taken from the taxpayer, at some considerable cost, and then transmitted to the beneficiary, again at some considerable cost? It would perhaps not be overstepping the mark to assume that for every pound so drawn, perhaps at the outside 15s. reaches the fortunate recipient. 'The rest has been dissipated in maintaining an army of persons engaged in the collection and distribution; veritable parasites these, who add nothing to the wealth of the community, but on the contrary consume it without making any return. 
And so we are brought to the consideration of the last part of the subject. We have considered in some detail the relative position of the employer and the workman, but, though these are the protagonists, the community at large is much more deeply interested in the question than any section of it. In the struggles between the parties, in the discussions of the merits which occupy so large a space in the daily Press while these are in progress, the one group which is never mentioned is that which is in fact most deeply interested. The protagonists are Capital and Labour in some particular industry. The prize which is fought for is the division of the price to be paid by the consumer-the whole of the rest of the community-for the article these two are engaged in producing.

Now, men and women are not essentially coal-owners or coal-hewers, ironmasters or ironworkers, mill-owners or mill hands. These are mere accidents. In one sense it may be claimed that the capitalist is the only producer of the article. His bolt is shot. His money is fixed to the ground, and will produce coal or iron or cloth, and nothing else. But the man who owns the capital is not so bound, much less the workpeople whom he employs to render his capital effective. Either can turn to any other employment he likes.

We all have our labour of various kinds and qualities to sell-that and nothing else. With that we must satisfy those primordial needs of which mention was made abore. 'The men in any employment, like their employers, have an infinite number of wants of varying character to supply. But each one of them is engaged in the production of some particular article. Are not two things obvious: The community, as a whole, will desire to have all the articles it needs, first, as cheap, and 
second, as abundant as may be. On the other hand, each one of us desires to sell the produce of our particular endeavours for the best possible price.

There appears to be a serious conflict here between each of us, regarded as producer and regarded as consumer. Rightly considered, however, this conflict will be found to be less serious than would seem to be the case at first blush. If the general proposition which has been advanced is granted, it will be agreed that much the greater part of the product of industry goes to the actual labour required for the process-if to that we add the amount needed to provide for management and administration, we have accounted for fully 75 per cent. of the cost of the article to the consumer. No class of the community that I am acquainted with professes itself satisfied with its share of the product. 'The workingmen-whether they be miners or ironworkers or cotton mill hands or engineers or agricultural labourers-all clamour for a larger share. The administrative staff' is no less dissatisfied. Railway clerks - to name only onehave formed a Union which claims to be recognised by the companies, and asks for greatly improred wages and conditions of service. In passing, it may be observed that in many respects no class can present much more cogent ground for their discontent than these persons. Here and there, by great exception, some divisions may be found willing to sacrifice part of very high rates of wage to compass better pay for some of their fellows, but this is so rare a case that it may safely be left out of the argument.

See what results from this state of things. No settlement which fails to satisfy all sections of workers will put an end to the trouble which is apprehended. IBut if we give to all everything they ask, we have enhanced the 
cost of all articles of consumption-and consequently the price. If the margin were very large, this would not necessarily be the case, but we have seen no such margin exists. A 10 per cent. rise in wages of all sorts leaves only $17 \frac{1}{2}$ per cent. to meet all the other charges, and this is quite insufficient for the purpose. Capital will not be forthcoming to supply the growing wants of the increasing population-let alone to afford a better standard. The numbers must $d$ windle, and those who remain be content with lower conditions. The State cannot interfere to mend matters. There are sinister rumours afloat as to the intention of the Government to continue after the war the various schemes, now in practice, to limit profits. How is it possible this will encourage capital to remain in this country, much less to come here? Besides, the complaint in the past has been that British industries have been allowed to languish for lack of enterprise. British wealth in money and in goods sought investment abroad. Why did it go abroad if not to earn a better return, and how is this outflow to be stopped if means are adopted still further to limit that return? No doubt an attempt would be made to prevent capital from going away, but what success is likely to attend such an attempt? If capital is to be laid under a writ of ne exeat, shall labour come under a like ban? Are we all to be bound to the soil as completely as was the Russian peasant of yesterday or our remote predecessors in feudal times? Such interference, if attempted, can have but one result, and that of a most disastrous character.

What, then, is the remedy? How shall we better distribute the product of industry and allay the unrest of which we hear so much? In my judgment there is only one way-by improving our methods of production. To effect this, the earnest and active unremitting co-opera- 
tion between those engaged in industry must be applied. No longer must we hear of strikes or lock-outs as the means of settling the wages to be paid. No longer must work be interrupted while two Unions wrangle as to whether a particular job belongs to one or the other. No longer must a man be supported by his Union when he refuses to mind two lathes because the custom of the Union confines him to one. No longer must an employer assign as a reason for cutting prices that the man's wages are too high.

To ask that such things should cease may seem a counsel of perfection, but it is only by looking upwards that we can rise. To accomplish all these things one first step is imperative-each side nust endeavour better to understand the outlook of the other. The more intimate the relations between the parties, the less likely is it that misunderstandings will arise. The fuller the information given by employers to their men, the better will these apprehend the limits with which their demands must be confined. In this way alone can a better division of the product of industry be accomplished. It will benefit the whole community. The men will have received more wages, the capitalists more profit, the consumer more and cheaper goods. Abundance will have been preferred to scarcity. 


\section{IX}

\section{By A. SUSAN LAWRENCE}

THE position of women in industry has been profoundly changed during the last three years. In pre-war days, the labour of women was subjected to special protection and to special restrictions. 'The Factory Acts forbade night work for women, and limited the length of their working day; while their range of occupation was restricted partly by custom and partly by Trade Union rules. These protections and these restrictions have almost entirely vanished. In the eyes of the Home Office, and in the eyes of the Trade Unions, a woman became a man for the period of the war. The point of view of these high authorities, however, could not completely change the actual facts. She was still a creature with special needs, and still, industrially considered, a person whose labour was exceptionally cheap, and whose bargaining powers were exceptionally weak. Gradually, and without any apparent plan, fresh legislation and fresh rules of a protective character grew up to meet the actual emergencies of the situation; and wage regulations, on an altogether unprecedented scale, and new and more drastic rules with regard to conditions of work, followed as a direct result of the altered circumstances and the abolition of the old limitations. 
Further, partly as a result of these changes, and partly owing to the increased importance of women in industry, and to the general recognition of that importance, a new spirit has arisen among the workers themselves. An increasing sense of their own dignity, an increasing demand for the opportunity of living reasonable and happy lives, has undoubtedly arisen among them. 'This change has shown itself in many ways, the most notable being in a considerable extension of organisation.

It would appear, therefore, that the present is a favourable moment for permanently improving the conditions of life of the whole of the feminine working-class population. How low the level of those conditions was, and what are the chances of progress, can best be estimated by a short general review of pre-war conditions, and of the history of the last three years. These are naturally grouped under the three heads of wages, hours, and conditions of employment. The two latter subjects are dealt with very fully, and with expert knowledge, in another chapter. It is proposed here, therefore, to consider at some length the question of wages; and to touch upon the other questions in less detail, and merely so far as to indicate how far the appropriate methods for dealing with poverty may be adapted so far as to cover the whole field of industry.

Before the war, women, taken as a whole, did not enjoy wages sufficient to provide for the necessaries of life, and for a reasonable margin of emergencies. The great exception to this statement is, of course, the cotton trade. It is also true that one or two minor industries provided a satisfactory living for the majority of those engaged in them. In the great majority of trades, however, porerty among women was general and was often acute. So wide and sweeping a statement demands 
detailed justification; and the materials for that justification are, unfortunately, only too abundant. The published returns of the Board of Trade are accessible to all, and should be familiar to any serious student of wages. In view of the extreme importance of the subject, and in order to bring home to the public the true facts of the pre-war situation, the writer, however, makes no apology for giving once again a summary of the figures published by the Board of 'Trade during the years 1908 to 1913, under the title of an "Inquiry by the Board of Trade into the Earnings and Hours of Labour of Workpeople in the United Kingdom, 1906." That summary is set out in the tables given on pp. 208-210.

In considering these figures, the two chief points to note are, first, the extremely low average wages paid in the trades in which the majority of women are occupied; and, secondly, that the proportion of those at very low wages (10s. and under) is negligible in but few cases, and rises in many to a considerable fraction of the total. Again, the earnings given are those for a full week's wages. No account is taken of the inevitable periods of slackness or unemployment. The tables relate, it is true, to a time eight years before the war. It is equally true, however, to say that it is impossible to point to any large or general rise in women's wages since that time, with the exception of the eight trades which during that period have come under the operation of the 'Trade Board Act. ${ }^{1}$ For that reason, wages in the tailoring trade have been omitted, as now obsolete. The classification adopted by the Board of Trade does not admit of

1 These trades are chain-making, lace-finishing, tailoring, tin-box trade, paper-box trade, sugar confectionery, hollow-ware, shirt-making, and linen embroidery in Ireland. 


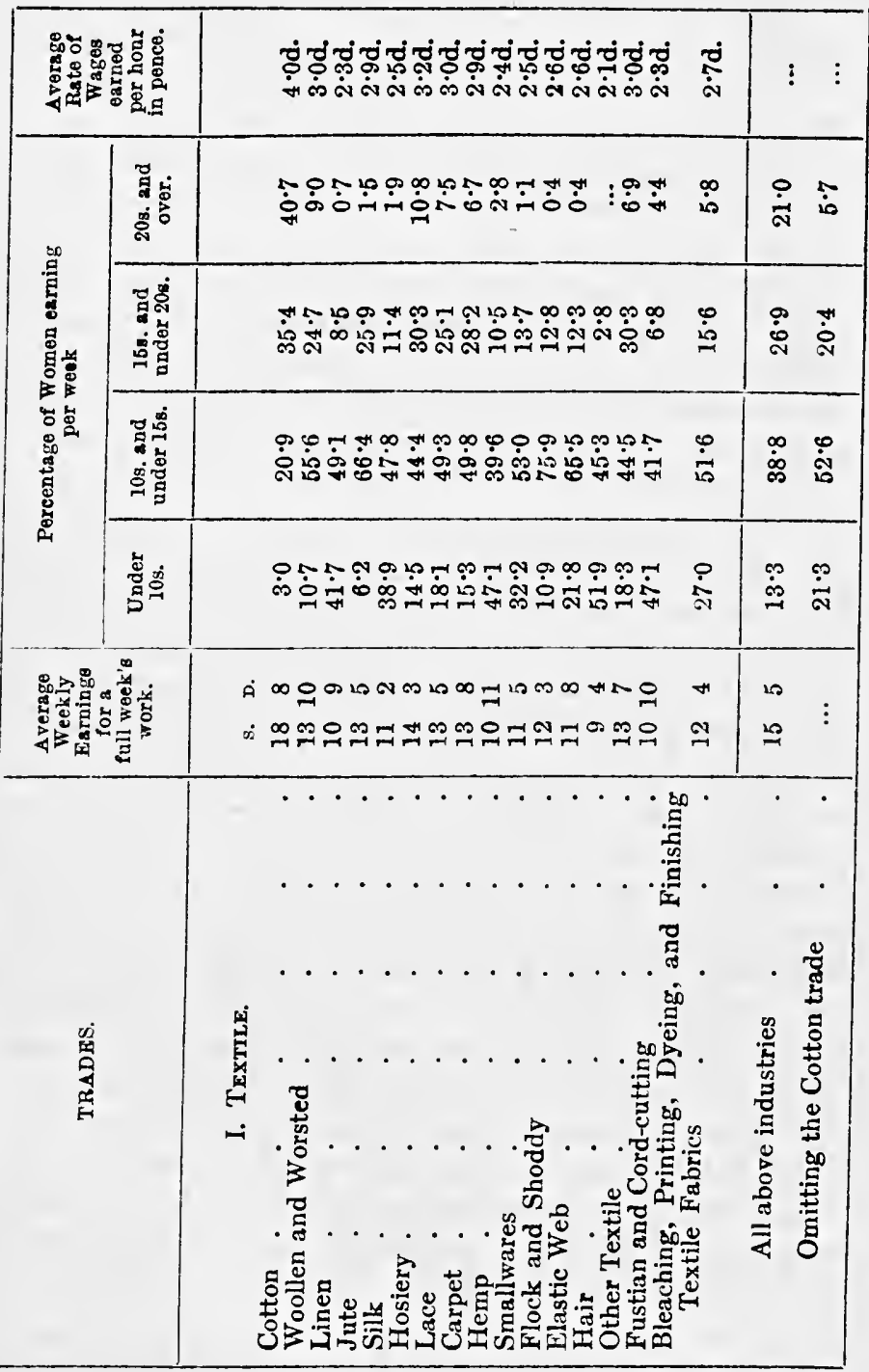




\begin{tabular}{|c|c|c|c|c|c|}
\hline \multicolumn{2}{|c|}{ 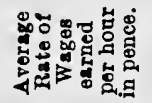 } & 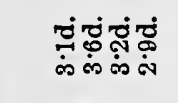 & 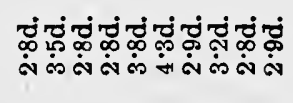 & $\vdots$ & 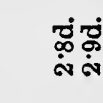 \\
\hline \multirow{4}{*}{ 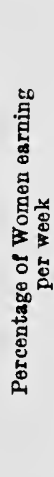 } & 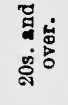 & 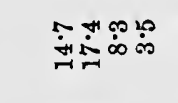 & 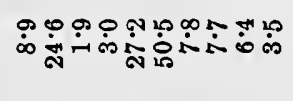 & 훔 & ن \\
\hline & 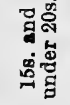 & 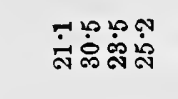 & 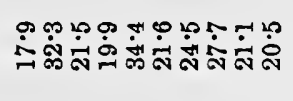 & 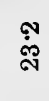 & ڤ̊ \\
\hline & 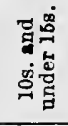 & 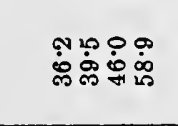 & 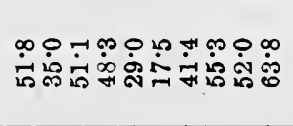 & is & 范藏 \\
\hline & 苞 & 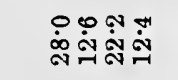 & 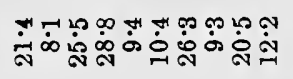 & $\stackrel{\leftrightarrow}{\dot{\sigma}}$ & 穴 \\
\hline 过 & ن & 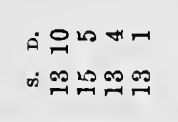 & 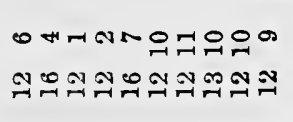 & $\stackrel{\infty}{\infty}$ & 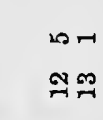 \\
\hline & & 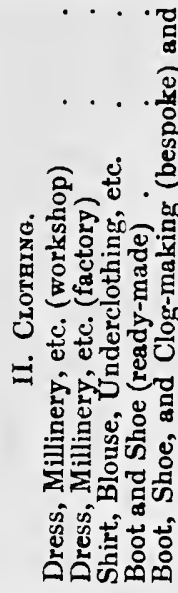 & $\begin{array}{c}\cdots \\
\cdots \\
\cdots \\
\cdots \\
\cdots\end{array} \ldots \ldots \ldots$ & 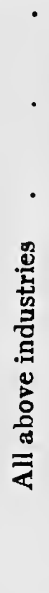 & . \\
\hline
\end{tabular}




\begin{tabular}{|c|c|c|c|c|c|c|c|c|c|}
\hline \multicolumn{2}{|c|}{ 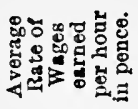 } & \multicolumn{2}{|c|}{ 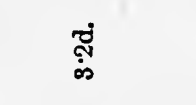 } & 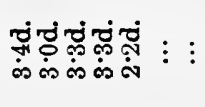 & $\vdots$ & $\vdots$ & $\vdots$ & $\vdots$ & $\vdots$ \\
\hline \multirow{4}{*}{ 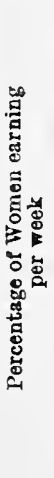 } & 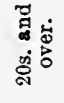 & \multicolumn{2}{|c|}{$\ddot{\circ}$} & من & $\stackrel{\varphi}{0}$ & $\stackrel{\infty}{\stackrel{\infty}{+}}$ & $\stackrel{?}{\underset{*}{*}}$ & $\ddot{\varphi}$ & קه \\
\hline & 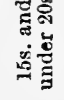 & \multicolumn{2}{|c|}{ 市. } & 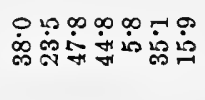 & $\stackrel{\varphi}{i}$ & $\underset{10}{\infty}$ & $\underset{i n}{i s}$ & $\min _{n}^{+4}$ & 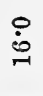 \\
\hline & 总离 & \multicolumn{2}{|c|}{$\stackrel{\varphi}{\dot{0}}$} & 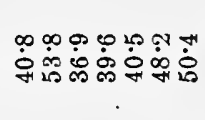 & $\stackrel{\infty}{\infty}$ & 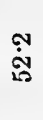 & $\dot{s}$ & 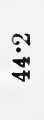 & $\ddot{\dot{m}}$ \\
\hline & 岁总 & \multicolumn{2}{|c|}{$\underset{⿱ 亠 䒑}{+}$} & 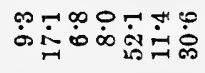 & $\stackrel{m}{\ddot{m}}$ & $\begin{array}{l}e_{0} \\
\stackrel{\infty}{N}\end{array}$ & $\stackrel{\dot{\phi}}{\dot{n}}$ & $\stackrel{\infty}{i}$ & is \\
\hline 政 & ن & \multicolumn{2}{|c|}{$\begin{array}{l}\dot{A} \infty \\
\dot{\infty}\end{array}$} & 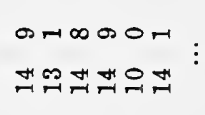 & $F$ & $\stackrel{N}{\stackrel{N}{N}}$ & $\begin{array}{l}\stackrel{0}{-1} \\
\rightleftharpoons\end{array}$ & $\begin{array}{l}20 \\
=1\end{array}$ & $\vdots$ \\
\hline \multicolumn{2}{|c|}{ 芧 } & 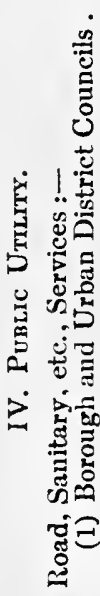 & 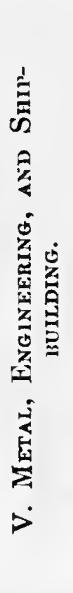 & 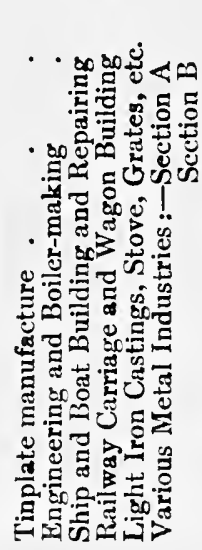 & 告 & : & 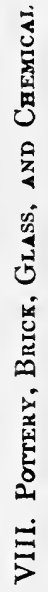 & 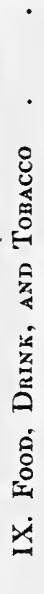 & 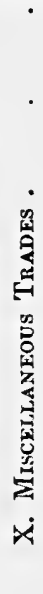 \\
\hline
\end{tabular}


the separation of the other protected industries. (It may be stated, however, that the pre-war wages of those now under the Sugar Confectionery Trade Board approached so closely to the general level of the food trade, that the exclusion of these workers would not materially have altered the average given for the whole industry. These figures may therefore be taken as representing, with sufficient accuracy, the condition of the remaining sections of the industry in 1906.) With these reservations, therefore, the Report of 1906 may be considered to afford a general representation of the conditions of women in industry prior to the war. It may be of interest to illustrate the matter further by quoting an extremely important Trade Union agreement signed by the Midland Federation of Engineering Employers in the year 1913. The rates are applicable to women in the Black Country and Birmingham area, and provide for a minimum rate of $9 \mathrm{~s}$. a week at eighteen, rising by yearly increases to $12 \mathrm{~s}$. a week at twenty-one. It may be reasonably supposed that these rates were somewhat better than those paid to unorganised workers by nonfederated firms. The fact that such wages were paid by representative firms shows that, as far as the centre of the metal industry was concerned, but little progress had been made in the years preceding the war.

We may fairly, therefore, say that, prior to the war, the remuneration of women was unduly low-low both in relation to the actual needs of the worker and in companion with the general level of the wages paid to men.

Such was the general situation at the outbreak of the war. There then came upon this country an urgent demand for production and a great shortage of male labour. 'The effect of this double strain was to encourage 
the subdivision of labour and the introduction of approved machinery, and to introduce women into men's occupations. The passing of the Munitions Act of 1915 marks the beginning of this period.

This Act introduced special regulations with regard to workers employed wholly or mainly on or in connection with "munition work," a term later extended to cover any articles intended for use in war. With regard to these workers, strikes and lock-outs were almost wholly prohibited and compulsory arbitration substituted; Trade Union customs "tending to restrict output" were abolished; and the right of the worker to sell his labour freely in the open market was subjected to severe restrictions.

The second of these provisions cleared the way for the employment of women; and by July 1915 the substitution of women for men began in earnest.

According to the canons of orthodox political economy, the new demand for the labour of women should of itself have been sufficient to raise their wages. 'This was only the case to a very limited extent, for several reasons.

In the first place, the restrictions enumerated above had of themselves a tendency to depress wages. If the worker may neither strike when she pleases nor leave when she pleases, it is difficult to see by what means, except by moral suasion, she can exercise much influence upon her rate of wages.

But other causes were also operative. Great as the demand for women was, the supply never-as a wholefell below the demand. Even now, though it is estimated that about 1,000,000 additional women have entered industry, there appears no sign of any general shortage on women's labour. Again, as has already been sufficiently stated, both the employers of women and the women 
themselves were accustomed to exceedingly low rates of wages. Finally, the majority of the women were unorganised; the new workers were necessarily so ; but even among the others organisation had proceeded but slowly. The Labour Year Book for 1913 estimates that in that year only 356,963 women were organised, and that, of these, 257,281 belonged to the textile trades.

The result of all these causes was that, for a considerable period, women's wages showed no upward tendency.

This fact was brought home with especial force to the members of the Amalgamated Society of Engineers. During the summer of 1915 , an inquiry as to the wages of the women substitutes was made by that Union. It was found that in the better class firms a wage of $15 \mathrm{~s}$. a week was customary, while some descended as low as $12 \mathrm{~s}$. These low wages were paid in the manufacture of shell, where, by common consent, the output of the women has been found to be exceedingly good.

The engineers entered into an alliance with the National Federation of Women Workers; and after long and protracted struggles, provisions with regard to women's wages were inserted in the Munitions of War Amendment Act, 1916. By this measure the Minister of Munitions was empowered to make wages orders in respect of those women who were no longer pernitted to sell their labour freely; that is, for all those for whom learing certificates were necessary. The first-fruits of this clause was an order issued in February 1916, regulating the wages of women who had undertaken the work of men in certain cases. 'This order has now been applied to nearly the whole of the metal trades, but by no means to all the occupations where women have replaced men in munitions work. The substitution of women for men has proceeded at a great rate in many 
other industries, without special safeguards for the protection of the men's rates, except such as the Unions have been able to secure for themselves.

'The order itself has passed through many modifications. At the present moment the lowest time-rate preseribed is a rate of $6 \mathrm{~d}$. per hour, plus a recent weekly advance of $2 \mathrm{~s}$. $6 \mathrm{~d}$.; i.e. a rate of about $6 \frac{1}{2} \mathrm{~d}$. per hour. The time-rate for women undertaking the work of fully skilled men must be that of the men they replace. 'Iimerates may, for work of an intermediate class, be settled either by agreement, subject to the approval of the Minister, or by arbitration. Where a system of payment by results is in force, equal pay must be given for equal work. The interpretation of these rules has been the subject of much arbitration. It may perhaps be mentioned that the highest time-rate for semi-skilled work was reached by women crane-drivers in a firm at Glasgow, who secured a rate of $10 \frac{1}{2} \mathrm{~d}$. an hour. Women replacing men on piece-work are also often able to earn fairly high wages.

So far, we have dealt only with women who replaced men on munitions work. A considerable part of such work had, however, always been considered as a woman's province. Here events followed a somewhat different course, but with not dissimilar results. 'The first Munitions Act, as has already been stated, gave the workers the right to demand arbitration; and the organised women were not slow to take advantage of this privilege. The National Federation of Women Workers was the first to move, and by their efforts (helped later by those of other Unions) decisions were given affecting wages in firm after firm and in trade after trade. The situation thus created made general action on the part of the Government both easy 
and necessary; and during the years 1916 and 1917 a very long list of orders and amendments to orders have been issued, applying to women engaged on "women's work" in munitions.

'The lowest time-rate prescribed is a rate of $5 \frac{1}{2} \mathrm{~d}$. an hour, plus an addition of half a crown a week; roughly speaking, that is an hourly rate of a little over $6 \mathrm{~d}$. An extra halfpenny is given in certain occupations. For the pieceworkers a minimum guaranteed rate of $4 \frac{3}{4} \mathrm{~d}$. has been fixed. Piece prices are to yield at least a third more than this rate; and half a crown weekly must be paid in addition. These piece-rates are true minima; and much higher sums are frequently earned. Exceptions have been made in the case of certain rural districts where the rates are a farthing less than those quoted above.

'The above orders were applied first in the United Kingdom, and were only extended to Ireland during the course of 1917.

As has already been stated, the Munitions of War Amendment Act of 1916 gave the Minister power to regulate wages, for those workers for whom leaving certificates were required, and for those only. He had power, that is, over all controlled firms, and over a certain number which were not controlled. In consequence, certain firms engaged on munition work in the trades enumerated above were not subject to wage regulations. The further amending Act passed last August extends these powers. He may now, if he so pleases, dispense with leaving certificates altogether; if he follows this course, he has power to extend his orders to all women munition workers. Recent speeches in the House of Commons show that leaving certificates for women will shortly be thingss of the past. 
Sumining up what has been said above, we see that a considerable measure of protection has been granted to women on munition work; that the lowest rate fixed is equivalent to about $6 \mathrm{~d}$. an hour; and that this minimum applies to a large number of women who during the war have been engaged in their original occupations. This may seem a very considerable rise when compared with the 1906 figures. If we take into account, however, the rise in the cost of living, we shall see that the gain in real wages is much less than the increase in money wages. 'The rise in the cost of living has been estimated by the Board of 'Trade as more than 70 per cent. ${ }^{1}$ Sixpence, that is, only goes as far as about threepence-halfpenny before the war. Measured, therefore, in real wages, at pre-war standards, the lowest rates fixed by the Minister of Munitions stand at about the same level as the minima fixed by the respective trade boards for the tailoring and shirt-making industries. To say this is not to deny that a good deal has been accomplished. If the minimum in the metal trades, for instance, had been raised to $3 \frac{1}{2} \mathrm{~d}$. before the war, no one acquainted with the facts could have denied that a great iniprovement had been effected.

These wage-regulations, however, only hold good for the duration of the war. With the coming of peace, the Minister's orders, the Minister himself, and the whole structure of the Munitions Act will vanish; and there appears to be little cause for doubting that the inprovement in wages will ranish too. As far as the women engaged on women's work are concerned, we are dealing with trades where the workers have never been able to secure for themselves a tolerable standard of wages. It is true that organisation has progressed among them,

1 The rise in the cost of living is estimated at 75 per cent. in the August number of the Board of Trade Gazette. 
but those organisations are still new and relatively weak, and are unlikely to be able to bear the strain put upon them by the inevitable dislocation of industry, and by the contraction of some employments which must follow peace. Left to themselves, there appears to be nothing to prevent wages from reverting to their former level.

The women who have replaced men may seem, at first sight, to be in a different category. Definite pledges have been given by the Government that pre-war conditions shall be restored. It would seem, therefore, that such women must either leave their occupations or be retained on terms satisfactory to the Unions. Such a conclusion would be misleading. Certain Unions include the majority of those engaged in their industry, and have been able, as we have seen, to secure protection of their rates of wages. 'These may probably be able to secure either a literal fulfilment, or a satisfactory equivalent, of the promises made to them. In certain other cases, women have taken the place of men in firms, and even in industries, where organisation hardly exists, and where it is impossible to speak of any effective Trade Union custom.

The mere fulfilment of the pledges given to the Trade Unions would not therefore cover adequately all cases where, during the period of the war, women have been engaged on men's work. There is a serious danger that a considerable number of men will find themselves replaced after the war by poorly paid women. Such women would be in much the same position as those dealt with above.

There remain finally the women workers who have continued at their old occupations, and who have not come under the scope of the new wage regulations. 
Speaking gencrally, money wages have risen with them, but not to so great an extent as to overtake the increased cost of living. 'The course of wages in the Midlands furnishes an instructive example. Earlier in this chapter, particulars were given of an agreement affecting women in metal industries in the Black Country and Birmingham districts. 'The minimum fixed by that agreement varied from $9 \mathrm{~s}$. at eighteen to $18 \mathrm{~s}$. for women of twenty-one and over. The Midland Employers Federation has recently concluded a new agreement to apply to firms in those districts which have not received wage orders from the Ministry. 'The new rates vary in the Black Country from $16 \mathrm{~s}$. $7 \mathrm{~d}$. at eighteen to $19 \mathrm{~s}$. $7 \mathrm{~d}$. at twenty-one; the rates in Birmingham are 1s. higher. These advances are "to be recognised as dependent on the existence of the abnormal conditions now prevailing in consequence of the war." 'The advances given, it will be seen, are a rise of a little less than 70 per cent., almost, but not quite, equivalent to the increased cost of living. These workers, therefore, in an area especially exposed to the competition of munition firms, have just managed to maintain their pre-war position, but have by no means reached the level of their neighbours on munition work. In other areas, worse instances could be given. To take but one of these, the Staffordshire Potteries Manufacturers Association signed an agreement in March 1916, by which warehousewomen of twenty-one years old should receive a wage of 12s. a week; and women in the dipping house, rates of from 10 s. to $13 \mathrm{~s}$., subject in all cases to a 10 per cent. war bonus.

Certain exceptions no doubt exist; but, speaking generally, it may safely be said that, outside the scope of the orders and awards made under the Munitions Act, women have not been able to raise their wages in proportion 
to the increased cost of living. The pre-war position is substantially unaltered as far as they are concerned; and there appear to be no tendencies at work likely to alter that position.

During the war, therefore, there has been a rise in real wages as far as munition workers are concerned; and a rise in money wages (though not in real wages) for other classes of women. Both classes of workers are likely to find themselves in much the same position after as before the war. There appears, therefore, to be good reasons for some general legislation with regard to wages.

Before considering what form that interference should take, it will be useful to discuss the present position with regard to the length of the working day, and to conditions of labour. In 1914 the legal maximum hours of employment for women had remained substantially unaltered for about forty years. A working day of ten and a half hours, and five hours of continuous labour, were still permitted. An amendment of the Factory Act had been long demanded, but the legislature, occupied with matters of more pressing political interest, had found itself unable to touch the question.

With the outbreak of the war came a demand for increased production. There instantly arose from the employers a demand for lengthened hours; and the appropriate departments hastened to meet that demand. 'The working week was increased during the first eighteen months of the war to almost incredible lengths. "For many months," one report states (dealing with a very large fuse factory), "the hours of labour had been usually $77 \frac{1}{4}$ a week, except that on the second week of each month there was no Sunday labour, or the hours were reduced to $69 \frac{1}{4}$ per week." The folly of such treatment of the workers 
is manifest. No subject has been more fully and elaborately discussed than the relation of output to length of hours; and nothing has been more firmly established by actual experiment than the fact that, after a certain length of working day has been reached, output declines instead of increasing. When the pressure came, however, it was seen that nothing had been learnt and nothing had been forgotten since the days of the first attempts - nearly a century ago - to regulate hours. 'Those responsible seemed still to believe that output varied proportionally with hours; and actual experience was needed to convince them that the rule of three had its limitations; and that a worker could not do twice as much work in sixteen hours as in eight. Hours, as we have said, were lengthened in the supposed interests of production; and it was found, as it always will be found, that to exact unreasonable toil from the workers defeated its own object. One case of unreasonably long hours has been given, and it will be instructive to follow what happened. The pressure upon the workers became unendurable, and the hours were reduced first to 74 a week and subsequently to 66 ; careful records being kept as to production. It was found that during the second period output rose by 8 per cent. The surprised and delighted employer reduced the hours to 56 per week, and though no record of production during this later period has been kept, it must be presumed that the result was satisfactory, as the shorter hours have continued since. The country generally learnt the same lesson at about the same time; and during 1916 the control of the Hone Office began again to be felt. An order was issued in September of that year, imposing a weekly maximum of 60 hours for girls and women. That date may be taken as closing the period of almost unbridled licence with regard to hours; though the maximum still 
remains too high, and there is even reason to believe that some very important Government factories frequently exceed it.

Now, no scheme of social rcconstruction is possible so long as the worker is condemned to a round of ceaseless toil, without leisure to lift her mind above the mere daily necessities of life. No national prosperity, no trade activity, can compensate for such a sacrifice; even if such prosperity could be so attained.

The history of the last three years shows how hardly the old fallacy dies, that long hours mean high output; and gives cause to fear that, should there be a great trade revival after the war, we may see the old ignorant demand for a long working day again ignorantly pressed. That demand must be resisted, both in the interests of the workers and of the community. Stronger barriers must be erected than those which fell so casily at the first attack. The war customs form an evil precedent, and have accustomed industry and public opinion to long hours; and the position of the worker has been correspondingly weakened. It is all the more necessary, therefore, to press for a compulsory and universal shortening of the working day.

The situation with regard to conditions of employment is more encouraging. There has been a widespread interest in women's work, and a considerable amount of genuine sympathy has been excited. The Government, too, has become an employer on a very large scale; and while Government establishments are not, generally speaking, above the average in matters of hours and pay, the new Government factories are often worthy of very high praise as far as the arrangements for the health and comfort of the workers are concerned.

The Home Office and the Ministry of Munitions have 
both exerted themselves, with some success, during the war to use the new standards, and the new feeling, to improve working conditions generally. More valuable, however, are the extended powers which have been conferred on the Home Office. A short Act was passed in 1916, Police, Factories, etc. (Miscellaneous Powers) Act. This measure gives the Home Office power to make orders enforcing suitable arrangements for meals, drinkingwater, and first aid, for washing, for supervision, for the use of seats, for numerous conveniences and amenities, that is, which have hitherto been left to the discretion of the employer.

This is a great step forward, and the many good consequences which may ensue have been fully described elsewhere in this volume. The Act, however, is not altogether perfect; and, under present conditions, its successful administration appears difficult. In the first place, if there is general objection to the orders made by the Home Seeretary, those orders must be submitted to a referee for settlement. Such a provision (though applied to other industrial matters) appears unsatisfactory. 'The responsibility of the Minister, and the possibility of effective parliamentary criticism, vanish altogether. The ultimate authority in such important matters becomes neither a body representing the nation nor a body representing the industry concerned, but an individual. It may well be doubted whether any individual can combine the necessary qualities of complete detachment and absolute knowledge. But, supposing such difficulties are surmounted, and orders of absolute perfection are issued, they will still remain waste paper unless efficient means exist for thcir enforcement. Ifere we touch upon an old grievance. 'The staff' at the disposal of the Home Office is inadequate. 'The women factory inspectors have 
never been sufficiently numerous. The new Act loads fresh burdens upon an already overworked body of public servants. It is idle to expect that orders relating to so many matters of detail can be properly administered unless the inspectorate is strengthened.

The above brief and general review shows three things. There has been a considerable improvement in the wages paid to certain classes of workers. This improvement is due to State regulation, and is not likely to be maintained when those regulations come to an end. The hours of labour have been lengthened beyond those customary before the war, long as those hours wcre. In certain classes of factories, conditions have been improved; and the Home Office has power to raise the standard in all. We have seen that in all these matters more remains to be done. If that is so, what form should our practical proposals take?

To one school of thought, the answer appears perfectly simple. Let us have, they say, a national minimum wage fixed by Parliament; let us reduce the hours of labour by some amendment of the Factory Act; and let us trust the Home Office to exercise with energy and courage the new powers conferred upon it by Parliament. The solution is too simple. Parliament has neither the detailed knowledge nor the infinite leisure needed for dealing with the intricacies and the complexities of industry. If the general good-will of the community is to be translated into practical effect, we need new machinery, and we need, above all, means of utilising the technical knowledge and enlisting the continuous cooperation of those concerned.

Consider, in the first place, the proposal that a universal minimum wage should be fixed by legislation. 
The idea is supported by a certain body of opinion, and is, at first sight, mndoubtedly attractive. There are, however, many reasons against this policy of the short cut. A national minimum must necessarily be a minimum suitable to the very lowest and worst paid industries. Here and there throughout the country are small and struggling industries where any great or immediate improvement of conditions might actually be, and would certainly be said to be, a burden too great for the industry to bear. Persons well qualified to judge, believe, for instance, that the transference of the fur-pulling trade from London to the Continent is due to the enforcement of exceedingly moderate sanitary conditions. Cases of industries on the verge of extinction are probably very few in number, and employ but few workers; but if a national minimum is fixed these marginal trades are the very ones which must be considered. The legislature would thus be forced to take the standard applicable to the worst paid and least hopeful industries; and if this is done, it is obvious that no general improvement can be expected.

Fortunately, we have ready to our hand an instrument of great delicacy and precision. 'That instrument is the Trade Boards Act of 1909 . Under that Act the wages of about 300,000 persons in eight trades are already subject to fixed ininima.

Its main provisions are as follows:-In the first place, the Act is applicable only to trades where the rate of remumeration is exceptionally low. It may be applied by provisional order to every trade coming within that definition, and has-as has been already stated-been so applied to eight trades. For such industries a Trade Board is established, consisting of representative employers and workers, together with certain persons appointed by the 
Ministry of Labour. This body has the power to fix minimum wages for the workers, or for any section of workers employed in the industry concerned.

We have here, therefore, a commitlee of experts, where minimum rates applicable to each trade are decided after consultation between representative employers and workpeople. Rates of wages so settled correspond far more accurately to the circumstances of the particular industry, and are likely to command more universal assent than wages settled by some outside authority. In fact, the success of the Act to those industries to which it has already been applied is generally admitted. It is here suggested that to widen the scope of the Trade Board Act so as to cover the great majority of women workers would afford a satisfactory solution of the wages question. No new principle is involved; the difficulties in the way of so great a development are difficulties of machinery and administration.

It may be said with truth, that the Trade Boards, whatever their other merits may be, are exceedingly slow in getting to work. The mere definition of the scope of any particular board needs detailed inquiry by the Board of Trade; the selection of representatives of the whole of the industry is a matter which cannot be hurried. Such mere preparatory measures consume much time. And when the board has been set up, its procedure has been found to be by no means fast. There is much force in these contentions; but such difficulties are not insuperable. Trade Boards do, it is admitted, act with excessive slowness. They do so, however, not because they are Trade Boards, but because they have bcen statutorily compelled to adopt an excessively slow and complicated procedure. At the present time, for instance, after the board has decided on a rate, a period of at least nine months must 
elapse before full legal effect can be given to its decision. A very small amendment of the present Act would give the boards more liberty of action.

Again, in the case of the industries affected by the present wages orders, it is not unfair to say that the bulk of the work has been done. The most difficult task of such boards is not so much to determine what is a reasonable standard of living, or even to settle "what the trade will bear." 'The real practical difficulty has always been to adjust the rate as nearly as possible to the practice of the best employers, without creating too great a disturbance in the methods of the others. In a great part of the munition trades a uniform standard has already been introduced; employers and workpeople have become accustomed to its operations; and the industry has adjusted itself to the new conditions.

If, therefore, 'Irade Boards can be formed to take over these trades at the moment when the orders lapse, they will find their task comparatively easy. IVe may therefore hope that the new boards will act more quickly than the old. They cannot, however, begin to seriously consider the questions before them until peace conditions have been restored: and it is obviously impossible to estimate the time which the Ministry of Labour may have at its disposal before the conclusion of hostilities for carrying out the necessary preliminaries. It is therefore possible that it may be necessary to adopt some special measures to deal with wages for a liniterl period after the conclusion of hostilities. Should such a case arise, it could be met by a comparatively short extension of the present regulations with respect to wages. 'There would appear to be no very great difficulty in allowing the present orders to remain in force, unless and until the appropriate board had fixcd other rates. The extent to which such a plan 
might be necessary depends so entirely upon circumstances which it is impossible to forecast that any detailed discussion at this stage appears unprofitable. By the above plan minimum rates of wages may be dealt with by representative bodies of employers and employed. The question now presents itself, whether further advantage cannot be taken of the knowledge and experience of such bodies; and whether, in particular, this machinery may not also be applied to the regulations of hours.

It is undoubtedly true that the establishment of a maximum working day by statute has been of untold benefit to women; it is equally true that a further lowering of that legal maximum is necessary. We do, that is, need an amendment of the Factory Acts. But it is not necessary to stop here. The slowness of parliamentary procedure, the want of time, and of detailed knowledge, make the regulation of hours a cumbersome process, and one which can only be resorted to at long intervals. It is suggested, therefore, that each 'Trade Board working within the limitations of the Factory Acts should have power to deal with hours of labour. A Trade Board, that is, might fix, if it so desired, a shorter working week than that prescribed for the country as a whole. It is easy to see how great would be the value of such discussions in such bodies. The relation of hours to output, for instance, varies almost certainly from occupation to occupation. All industries might profitably adopt a shorter working week, but the actual length of the week might very possibly vary in different trades. It is obvious that the decisions of a committee of experts upon such matters would be of great value; and that, working in this manner, and taking each trade separately, better and more speedy results might be obtained than by general legislation only. 
With regard to working conditions, the case is somewhat similar. The Home Office has, as we have seen, extensive powers; and both the knowledge and the good-will of the officials of that department are worthy of all praise. Very much good could be done by a mere extension of staff. 'That staif would, however, be assisted very greatly in their task if there were some ready means of consultation with a body representing the whole of the trades concerned. Take, for instance, the case already discussed, of the procedure necessary in issuing orders under the Act of 1916 . We have seen that such orders must, in certain cases, be referred to an umpire, and we have discussed the.obvious objections to such a course. Those objections would vanish if the required decisions were given, not by an individual, but by the Trade Board representing the industry. Similarly, it is easy to imagine how many other industrial grievances would be softened or removed by free discussion at such a tribunal. 'Trade Boards should therefore be given power to initiate inquiries on any matter connected with their industry.

'The scheme here sketched out is, in short, to supplement the Government control of industry as a whole, by the legislation of certain trades separately and from within. 'The workers for whom such special protection is necessary may be roughly defined as those whose remuneration is low, whose organisation is weak, and who have not been able to secure for themselves a tolerable standard of life. Unfortunately, as we have seen, such a definition would include the miajority of women employed in industry. Some persons may fear that such assistance would weaken or destroy the desire for organisation. On this point, however, experience shows that the setting up of a scale of minimum wages has, 
in actual practice, been found to promote, and not to hinder the organisation of the workers concerned. Both among women subject to the Trade Boards Act, and among those subject to the orders of the Ministry of Munitions, organisation has been stimulated. The organisation of the tailoring trade, and the great and rapid growth of organisation among munition workers, are cases in point. Such assistance, in fact, gives poorly paid workers the hope and the encouragement necessary to establish Unions of their own.

These proposals, it may be added, would seem to indicate some modifications in the work of the Government departments concerned. Trade Boards have been recently transferred from the supervision of the Board of Trade to that of the Ministry of Labour. 'They and that department deal at present only with wages; the Home Office regulates hours and conditions of employment. Both departments maintain a separate inspectorate; and neither department is sufficiently staffed. It would seem, therefore, that ease and economy of administration would be effected by a further extension of the powers of the Ministry of Labour; while, on the merits of the case, it would appear highly illogical that the Minister of Labour should have nothing to do with the length of the working day, or with the rules for the good conduct of a factory. It is therefore suggested that the newly created Minister of Labour should enlarge his sphere of action; and that the duty of administering the Factory Acts, and the staff engaged on that work, should be transferred to his department.

We have now discussed the pre-war position of women in industry, and the modifications produced in that position by war conditions. The general impression is one of hope. Much, indeed, must be done before healthy 
conditions of work, enough money to satisfy physical necessities, and enough leisure to lift the mind above those mere necessities can be secured to every worker. But there is little doubt that the country, as a whole, desires that these modest demands should be granted; and this power of the collective will of the community has never been more clearly shown than during the past three years. We have seen how absolutely bad conditions, long hours, and poverty itself are subject to that will, and can be altered or abolished as it dictates.

What is now needed is some simple and easily worked machinery through which practical effect may be given to such aims. It is hoped that the scheme which has been outlined above may meet that need.

Note.-The above chapter was written in August 1917 , and the facts and figures given are correct as at that time. Since that time the cost of living has increased, the leaving certificates mentioned have been abolished, and a demand for a general increase of wages for women has been formulated, and is now (December 1917) under the consideration of the Minister of Munitions. 'The position outlined, therefore, has changed in some important respects. 


\section{$\mathrm{X}^{1}$}

\section{BY B. SEEBOHM ROWNTREE}

Even now, when it almost seems as if the Empire's heart were beating, not in England, but out in France or Flanders, it is daily becoming of more vital importance to reach and to maintain a level of industrial efficiency which may assure the nation that its gigantic sacrifices have not been made in vain. During the past two years we have been told very frequently that Britain, no less than Germany, is fighting for her life. If so, we must see to it that the life which her sons have safeguarded with their own does not ebb away at home, stricken by some creeping malady that we have not troubled to arrest.

Now, the material life of a nation lies very largely in its industrial productivity. And, to have done with metaphors, it is clear that after the war, until we recreate the wealth which war has destroyed, the purchasing power of the people will be small, industry will be depressed, and the amount of poverty and unemployment will be correspondingly great. ${ }^{2}$ Therefore, the old,

${ }^{1}$ Reprinted, by permission, from The Nineteenth Century and After of February 1917.

"I think industry after the war will pass through three phases:

(1) Great dislocation for a few months ;

(2) Feverish activity for a year or two ;

(3) A long period of depression, unless sctive steps are taken to a vert it.

It is to this last phase that I refer above. 
haphazard, and often lagging rate of output will not meet the new need, and, unless we prefer to "go under," we must as a nation learn to make wealth more rapidly. What prevents us from doing so?

Briefly, it is that the system by which workers are rewarded for their services, and the general conditions under which they work, are not such as to induce them to do their utmost. Rather, within the present system, even now, when we are striving to cope with the war's unique demands, there is ample room for apathy, ignorance, and inefficiency, both among employers and employed.

I do not wish to enter into a theoretical discussion whether modern industry rests upon the best possible basis. Just now the urgent need is, assuming the present basis, to devise some better working system, which will materially increase the productivity of both Capital and Labour, while improving the relationship between them.

If we analyse the present situation more closely, we shall find that, speaking broadly, there are three reasons why workmen fail to do their best:

(a) There is no strong sense of partnership between Capital and Labour. They are to a great extent opposing forces, suspicious of each other; and, far too often, the energy which should be devoted to production is wasted in recrimination, if not in open hostility.

(b) Huinan nature, as a rule, prefers mild to strenuous activity. A man who is earning wages, therefore, inclines to work in a leisurely fashion, unless he has some strong inducement to "get a move on." A flat day rate of wages does not offer that inducement.

(c) Where, on the other hand, work is paid for on a piece-rate basis, the workers are often (not without cause) afraid that if they do their best the result may be the "cutting" of tho piece-rate.

Let us consider these difficulties in detail. 
Dealing first with the general relation between Capital and Labour, it is high time to face the fact that the hope of increasing the efficiency of British industry will primarily depend on the extent to which employer and employed can work harmoniously together. But first of all they must wish to work harmoniously, and many of them, as yet, have no such wish. Until they have, the discussion of plans and methods for their more complete co-operation will avail but little. I emphasise this aspect of the question because it is fundamental. There is no chance of peace, and, consequently, no chance of full industrial efficiency, unless both master's and men really covet peace, and are determined, so far as in them lies, to remove every occasion for strife. 'They must both set aside any personal or class bias, and recognise frankly and fully their own duties and the rights of other people. For many of us this will mean a radical change of outlook. But the efforts and the possible financial sacrifice which it will involve are the priceand after all it is not an exorbitant price-which we must pay for the establishment of a better industrial era, for national prosperity and abiding national greatness. And here, in passing, I should like to recall the fact that organised labour has recently given up many of its defensive strongholds, won after long years of struggle, on the express pledge of the Government that the old safeguards should be reinstated after the war. It is clear, however, that the many alterations in the conditions of industry which the war has brought about will make the literal fulfilment of this pledge extremely difficult, if not impossible. But it seems to me that when peace is declared employers are bound in honour either to facilitate the absolute fulfilment of the Government pledge, or to offer Labour some substantial concessions 
which it can accept as an adequate quid pro quo. If the workers have definite ground for believing that they have not been fairly treated in this matter, I see no prospect of future harmony.

Now, in pursuing the quest for industrial efficiency, the first problem that meets us is that of the level of wages. Men work, as a rule, to earn wages, and the whole relationship between Capital and Labour is very largely determined by the wages that are paid. Here, the primary condition to be fulfilled is that, with the least possible delay, all adult workers of normal ability shall receive as an absolute minimum a reasonable living wage. By this I mean a wage which will enable a man to maintain a family of normal size in a state of physical efficiency, and allow a small margin for recreation and incidental expenses. With prices as they were in July 1914, I should place the cost of providing the bare necessities of physical efficiency at about 26s. a week, allowing 5s. for rent, but this is on a very stringent basis and provides not a farthing for contingencies nor for recreation or any kind of luxury. A considerable addition must be made to this sum to turn this bare physical efficiency wage into a reasonable wage. Moreover, it must be remembered that the cost of living is very much higher now than it was and is not again likely to drop to the level of July 1914.

A woman should receive at least sufficient to maintain herself in respectable surroundings, and to allow some margin for recreation. Assuming that a woman, if not living at houe, lodges with a fimily, 1 should place her minimum wage, just prior to the war, at about $16 \mathrm{~s}$. Without discussing the question of equal pay for equal work as between men and women, I rule out the suggestion sometimes made, that a woman should be 
paid as a minimum enough to maintain a family. Minimum wages should be arranged with a view to normal conditions, and, though there are many exceptions, the normal condition is for the man, not the woman, to maintain a family.

No doubt many industries at first could not pay these minimum wages. From a long and considerable experience of working people, I do not believe that ill-feeling would be occasioned in such cases by the temporary payment of lower wages, if the workers knew that the proprietors or shareholders were very strictly limiting the profits or dividends declared, and straining every nerve to make a more satisfactory level of wages possible. Rather, they would fight shoulder to shoulder with the employer towards that desirable end. What rightly angers them is to see others thriving on their privation. ${ }^{1}$

So far we have dealt with minimum wages only. How can harmony be secured between Capital and those workers who command a higher wage than the minimum? In answering this question, let us first assume that the masters and men in an industry are all organised. In such a case the level of wage will be determined by bargaining between the representatives of the two organisations. At present this process is often conducted with bitterness, and sometimes leads to strikes and lockouts. But a mutual desire to arrive at a fair and reasonable agreement would dispel all bitterness. 'To-day it creeps into the negotiations because each party suspects that the other is considering, not the rights of

1 There is much to be said in favour of legislation after the war to fix a universal minimum wage, or at any rate to give the workers in any industry the right to demand the establishment of a Trade Board. But these questions lie outsicle the scope of this paper. 
the case, but solely its own interests. That suspicion in the future will have to die for lack of food! Whether in the name of justice, or in the name of patriotism, or in the name of common sense, when Labour and Capital meet, the one must be able to postulate correctly the desire of the other to "do a fair deal." Some of us, possibly, may not like at first to "do fair deals." But it would soon become a habit with us, one of which the whole community would reap the benefit. Under the "fair deal" regime, something like this would probably happen. A demand for higher wages would come from the workers. They would state their case-possibly that the prosperity of the industry had increased, or the cost of living had gone up, that some allied or comparable trade was now paying higher wages, or that some trade, in which by custom the wages ruled lower, had advanced its wages. Such reasons lend themselves to discussion and friendly settlement, and applications for increased wages would, as a rule, be based on them, rather than on any abstract theory, e.g. that Labour has a right to the whole product of industry. Such theories are firmly held by rery few, and although they may float nebulously in the minds of a large number, they are not at present likely to affect the policy or demands of any appreciable mass of workers.

When the organisation of an industry was less complete, or did not exist at all, the process of fixing wages would be somewhat different. Suppose, for instance, that the workers were more or less organised in Unions, but the masters were not federated. In such cases the Unions would deal with each firm separately. A rate of wages in the best-paying firms would soon be established, and this would become the standard which the Unions would seek to obtain for all the workers in 
the industry. There would probably remain considerable differences between the rate paid by different firms. The Unions would most likely expect the firms earning. the highest profits to take the lead in the matter of wages; but I do not think that any serious attempt would be made to secure wages out of all proportion to those generally paid throughout the industry from any particular firm simply because it happened to be earning exceptional profits.

In a trade with no organisation of either masters or men, the fixing of such wages as may promote harmony between Capital and Labour becomes largely an individual matter, and, assuming mutual goodwill, should not present serious difficulties. The case is fundamentally the same as where wages are being fixed in organised, or partly organised, trades, except that, as a rule, the employer is in a stronger position.

But some employers may say "Unless we fight every inch of ground, where shall we be in a few years? Are not the workers like the daughters of the horseleech, ever dissatisfied? Will not their demands increase as our concessions multiply?"

No doubt Labour will constantly seek to improve its position. But that fact need not alarm Capital. If eniployers meet the demands of the workers sincerely and sympathetically they will avoid the great direct loss of wealth due to strikes and lock-outs, and the indirect loss due to chronic friction and dissatisfaction, to an extent which alone would recoup them for considerable advances in wages. Moreover, Labour cannot demand higher wages than a trade can bear. This does not mean that a trade, or an individual business, must be ruined, or even crippled, before the workers believe that it cannot afford to pay a given wage. The closing of a single 
department in a mill because, under the new wage conditions, it could not be made to pay, would be an adequate danger signal to Labour to stay its hand, and if once confidence had been established between Capital and Labour, such a step would be unnecessary. It would suffice for Capital to explain (with satisfactory evidence) why higher wages could not be paid. The trouble is that in the past employers have often declared that they could not possibly afford a given wage, yet when they have been compelled to pay it, they have continued to trade and make their usual profits.

I prophesy that Labour will demand higher and yet higher wages more insistently in the future than in the past. But its demands will stimulate employers to make up for any consequent loss by more efficient management. Labour-saving machinery will be introduced, organisation will be improved, better methods of buying and selling will be adopted, and inventive genius will be stimulated in all directions. Many employers will be able, at any rate for many years to come, both to meet-Labour's claims and to maintain their margin of profit. No doubt some will find their profits declining, and a few, through lack of capital, lack of ability, or both, will fail to cope with the new conclitions and will be squeezed out. But industry as a whole will gain incalculably, and, from a national standpoint, it is obviously undesirable that a small minority of inefficient and ill-equipped employers should be allowed to retard industrial progress.

But though the payment of adequate wages strikes the keynote of industrial harmony, harmony is more than a keynote. At the present time, even in a "model" factory where the highest wages are paid, the workers remain servants. The employer, however kindly, practically controls their lives. He may employ or dismiss 
them at pleasure, work them short or long hours, and make rules of every description to regulate their conduct while at work. I am, of course, a ware that where Labour is highly organised, the employer's freedom of action is limited to a considerable extent by Trade Union action. But even here there is no real spirit of partnership; the position of employer and employed remains that of master and servant. I do not believe that any lasting harmony between Capital and Labour is possible under these conditions. Can a practical alternative be suggested? This is a matter to which many thinkers, both at home and on the Continent, have lately been giving much attention. It is coming to be widely recognised that industry needs the infusion of a new spirit-a spirit in which Labour is regarded rather as a partner than as a servant. What will this change of outlook involve? I believe it will involve the co-operation of the workers with the management, practically on equal terms, in determining the conditions of work in any industry.

Just what machinery must be set up for this purpose will be a matter for very careful consideration. It is clear that those who accept the ultimate financial liability must retain the ultimate control. But, recognising, as we must, that Labour is as essential as Capital to production, and that, whether they like it or not, the two are committed jointly to one business enterprise, it seems both just and reasonable that both should have a voice in determining the conditions of employment. It should be possible to devise a scheme whereby the management of a business could be very considerably democratised, with advantage both to Labour and Capital.

We have, so far as I know, few data in this matter, and experiments would have to be made tentatively, but 
I suggest a rough outline of a scheme, which might be introduced as a beginning, for the establishment in large factories of Departmental and also General Works Councils, consisting of representatives both of employers and workers.

'Ihe constitution of a Departmental Council might be somewhat as follows:-

Its members would be elected annually, by suffrage of all men over twenty-one, and all women over eighteen, who had been employed by the firm not less than three months and were on the regular staff. There should be one representative for every fifty workers of all ages.

Sitting with the Council, and having equal powers with them, would be the manager of the department, and the overlookers, sub-overlookers, and chargemen. Where these exceeded the workers, the members, apart from the manager and head overlooker, would be elected by ballot amongst themselves.

The manager of the department would be ex-officio chairman, but he would not have a casting vote. In cases of a drawn vote the matter would be submitted to the director at the head of the department or to the general manager for decision. No important decision of the Council would take effect until confirmed by the Board of Directors, who would have the power of veto or of referring the matter back for further discussion.

'The General Works Council would be constituted somewhat differently. If on the Departmental Councils there was one representative and one overlooker for every fifty workers, the total number of representatives, in the case of a large firm, would be too large to meet together for the consideration of matters affecting the whole works-e.g. 'Time Office rules, disciplinary methods, theft, etc. 
Therefore the Departmental Councils might meet (workers and overlookers separately) and elect (by proportional representation), say, fifty members to form a General Works Council (twenty-five overlookers and twenty-five workers).

'This Council should have the power of initiating discussion, but would not decide on the points discussed without first consulting Departmental Councils. Its chief function would be to decide on matters referred to it by Departmental Councils, and it would meet only when questions had been submitted to it by them, or when ten of its own members demanded a meeting, or the directors wished to consult it.

It would usually be presided over by a director, who would not vote. None of its decisions would take effect until confirmed by the Board, which would have the power of referring the matter back for further consideration, or of veto. Likewise the Trade Union might refuse to be bound by the decisions of the Council, and take up the question at issue with the management as it does at present.

In order that the interests of organised labour may be safe-guarded, each 'Trade Union concerned should be able to nominate one of its members who was employed in the factory to attend the Council meetings. The nominee of the Union would be empowered to speak but not to vote. If any matter was to be discussed which the workers thought of sufficient importance to require skilled assistance and advice, they should have the right to be represented by a Trade Union official, not necessarily in the employ of the firm, who would leave the Council meeting as soon as the special matter calling for his presence was disposed of. 
The duties of Councils might include:

(1) The criticism of any piece rate not thought to be fair and adequate, and the consideration of suggestions for adjustment.

(2) The regulation of the hours of work, when overtime or short time was necessary.

(3) Time Office rules, and disciplinary measures to enforce them.

(4) The formulating of new shop rules, which when put up should be signed by one representative of the management and one of the workers.

(5) The consideration, by a small sub-committee with equal representation of workers and employers, of all serious breaches of discipline, and of rules (which would be executed by the overlookers) for dealing with minor breaches of discipline.

(6) The consideration of complaints raised by individuals regarding any condition of work, aud the proposal of remedies.

(7) The discussion of all matters affecting the health of the workers, including the avoidance of accidents. Any recommendation made, after approval of a director, would be handed over to the business executive to carry out in the usual way.

(8) The consideration of means of increasing the efficiency of organisation-e.g. how to avoid the loss of time in waiting for material, etc., etc.

(9) The supervision of canteens and mess rooms.

(10) The organisation of all recreative activities.

These duties roughly indicate the amount of responsibility with which Councils might be endowed. Most of them might not pass beyond the Departmental Council, but the General Works Council would constitute a kind of higher court. It might be found that at present some of the above items could not be wisely entrusted to either Council, while many others, not mentioned, would naturally fall under their jurisdiction.

The Councils would not be responsible for such matters as-

(1) Policy connected with buying and selling.

(2) Appointment of overlookers or staff.

(3) The fixing of day wages, or the level to be aimed at in fixing picce wages. 
The last of these matters would be determined, as at present, by conference between the workers or their Trade Unions and the management.

I do not advise that the workers should have any representative on the Board of Management. Their elected representative might not have the qualification necessary for a seat on the Board, and unless he were spontaneously elected he would not really represent them. He would, moreover, on the Board be called on to deal with many financial and other matters which did not directly concern the workers, and with regard to which he probably would not have the requisite knowledge to justify his taking part in the decisions arrived at.

In considering the above scheme, it may be objected that, in so far as the number of matters to be decided by the Councils would be limited, and the directors would retain the power of ultimate veto, the workers' share in the management would be illusory. I do not think that the workers themselves would be of that opinion. 'To my mind, the proposals represent a great advance on existing conditions; and I am certain that the directors would not lightly veto a decision of the Council which had been arrived at after careful discussion. Moreover, this scheme is only put forward as a tentative experiment.

It may further be objected that to decide matters in this way is much more cumbersome than for the director or manager to decide them offhand, and issue instructions accordingly. This is true. But some price must be paid for understanding and goodwill between Capital and Labour. Democratic government is generally more unwieldy than autocratic government, but the spirit of the age is on its side. 
One more word with regard to Trade Unions. While recognising the need of safeguarding their interests, I think it is essential to the success of any scheme of democratic management of a factory that the workers and the management should meet, not as opponents, but in a spirit of co-operation. If Council meetings become mere opportunities for airing grievances they will fail to achieve their object-the creation of a sense of partnership. Grievances must certainly be discussed, but only as items among the many matters calling for consideration. As previously stated, however, it will always remain open to a Trade Union to refuse to be bound by the decision of a Council, and to discuss the point at issue directly with the management.

Let us pass to the second handicap upon output, namely, the fact that most men prefer mild to strenuous activity, and if paid by time incline to work in a leisurely way, unless some especial inducement is offered them to do otherwise. Many employers, when comparing their own cnergy with the somewhat indifferent attitude of their men, forget that they themselves, as a rule, are working for profits, which is the same thing as working "on piece." Moreover, even an eniployer who has no direct interest in the prosperity of the business he is engaged in (e.g. a managing director who receives a definite salary) is in a very different position from the labourer, or even the artisan paid by the day. Not only is his enthisiasm aroused by cluse personal association with those directly interested in the business, but he knows that sooner or later his successful administration is sure to be recognised in his salary, or will enable him to securc a higher post elsewhere. It is not so with the mere employee, who is often grimly conseious that however hard he works he will receive no higher pay. 
I doubt whether employers generally recognise the deadening effect of a day wage determined, not by the efficiency of the individual, but by agreement with a Trade Union, or by local custom, and applied indiscriminately to a whole class of men. What motive has the man working for it, whether under a private employer or a limited company, to do his best? Why should he force the pace, and thus involve himself in grave difficulties with his fellow-workmen, merely to swell the profit of his employer, or the dividend of shareholders whom he has never seen, and whose very names are probably unknown to him? He may have no desire to shirk his duty. But the custom of the shop has practically fixed the quantity of work to be turned out per man per day, and other men are being paid just what he is paid for turning out that precise quantity. Why should he do more? Surely, it is hardly reasonable to expect any other outlook!

This criticism does not involve a condemnation of the flat day rate system of payment under all circumstances. Sometimes the task to be accomplished in a given time cannot be delayed or hastened; for instance, that of a timekeeper or gatekeeper, the driver or conductor of an onnibus, a lift-man, and similar occupations. But take, on the other hand, wages paid to bricklayers, fitters, bricklayers' labourers, etc. In these trades a man has no direct inducement to excel in his work. He may know, indeed, that the best workmen are most likely to be made overlookers, and are always most secure of work; but that knowledge does not furnish an adequate incentive, hour by hour and day by day.

No doubt in small workshops an energetic employer who has won the goodwill of his men may inspire them, even when working on a fixed day wage, to do their very 
best. In the large modern factories, however, any close personal bond between employer and individual workman becomes exceedingly rare, and this is especially true in respect of limited companies. There may be no lack of kindly feeling on the employer's part, but it is physically impossible for him to enter into personal relationship with hundreds, or possibly thousands, of men.

In such cases a flat day rate of payment, common to all men in a particular grade, or doing a certain job, is almost certain to have a deadening influence on the workers, sterilising energy, initiative, and enterprisethree qualities essential to the health of the industry.

No doubt something can be done in the way of ensuring a good output even under that system. Speaking generally, it peculiarly needs good oversight, not necessarily close oversight, but oversight by men who can inspire and stimulate those working under them. The utmost care should be taken in the selection of a foreman over day workers. Again, a careful study should be made of the work they are engaged upon. A standard task should be set up which they should perform in a given time, and the man who failed to accomplish it should be dealt with by ordinary disciplinary methods. There is no doubt that much more could be done in this direction, though we must not forget that work which can be standardised can also, presumably, be paid "on piece." Where no standard task can be sete.g. in new or repair work which does not occur often enough to admit of standardisation, some stimulus can be given by increasing the wages of workers who show exceptional skill or industry. But eren such a stimulus is much less effective than a modified system of piece wage.

And now we will pass on to consider the perils and advantage of piecework. 
The principal reason which prevents pieceworkers from reaching their maximum efficiency is, as already stated, the fear that if they do so the piece rate will be "cut." This raises the whole question of the basis of a piece rate. It may be fixed on two principles. One is to adopt such a level that an average worker can earn a given wage, which wage is determined by bargaining between employer and employed. The other is, first, to meet the demand of the employer as representing the capitalist, and let the workman have the rest.

The former of the two methods is almost invariably adopted. It obviously involves considerable difficulties in fixing piece rates. Not unnaturally, during the process, the workers, knowing that their stock of energy is, as it were, being assessed, are not inclined to do their utmost. Sometimes, almost instinctively, they may work on the safe side of the speed they will adopt once the rate is fixed. Again, where new work is concerned, they do not at first possess the necessary skill to produce an output which practice would enable them to turn out with comparative ease.

In either case the difficulty of initially fixing the rate at the right level is very great, while to maintain a rate which has been wrongly fixed would be a serious blunder. The workers would certainly protest against a rate which was too low, and employers could not continue one which involved wages greatly in excess of current rates for similar services. For both those reasons modification of the rates paid in the first instance may be required until experience shows that a fair figure has been arrived at. ${ }^{1}$ But this modification

${ }^{1}$ Some advocates of what is known as "scientific management" claim that they have discovered a method by which piece rates can be fixed with scientific accuracy. A close examination 
may cause serious unrest, and, as already stated, the fear of it frequently checks production.

How can these difficulties be overcome?

$I$ do not propose to enter into the various systems of piece wages, such as plain piece wage, day wage with a bonus on output, collective piece (i.e. a piece wage shared by a group of workers), premium bonus syslem, etc., all of which, to a greater or lesser degree, give the worker a direct interest in the amount of output. I assume, however, that the picce rate which must be fixed is one which will enable a person of average capacity to earn a given wage in a given time. Presumably, the wage aimed at has been decided by bargaining, either directly between employer and employed, or through the medium of a Trades Union.

But, since it is quite impossible always to fix a piece rate accurately in the first instance, I think that the only way to avoid friction in its modification is to arrange that all piece rates shall be subject to criticism and, if necessary, to alteration by such Works Councils as I have described above, where they would be considered jointly by the management and representatives of the workers.

I do not think that many pieceworkers would deny that from time to time piece rates must be alteredwhat they complain of is the method of procedure. But if there were frankness on both sides the necessary changes could be made without serious difficulty. I should suggest that, before any modification in a piece

of their method does not, however, support this claim. By careful analysis of a job, and time studies of those engaged in it, a closer approximation to accuracy is gained than by a rough guess of a foreman. But many of the principal difficulties in arriving at an accurate result remain unsolved. 
rate became operative, the proposed rate, and the reason for fixing it, should be submitted to the Departmental Council, where both workers and management would have an opportunity of discussing it in detail.

Before concluding this discussion of methods of increasing the productivity of industry, a few words must be said on the question of profit-sharing. Many experiments have been tried, under a great variety of conditions, in systems of profit-sharing. A perusal of the literature on the subject, both official and otherwise, leaves a clear impression on my mind that, with certain exceptions, profit-sharing has not succeeded in bringing about really satisfactory relations between Capital and Labour. The reasons for the varying success of the system are fairly clear, when we remember that the contributions which the workers can make to the prosperity of a business (i.e. to the amount of the profits) are of two kinds:

(a) The performance of their various tasks, upon lines laid down by the management, with energy, diligence, and intelligence.

(b) The suggestion of improvements in processes, machinery, organisation, or the economical use of material.

The relative importance of the first factor varies with the proportion which wages bear to the total cost of production, and also with the extent to which the value of the product depends upon the close and intelligent carrying out of rules by the workers, and the possibility of detecting any neglect on their part before serious harm results.

Among productive industries, market gardening is a good illustration of those in which the diligence, care, and skill of the rank and file workers play a very important part in the success of the enterprise, and in 
which the proportion which wages bear to the total cost is high. But many industries are of a very different character. Frequently the cost of labour represents a comparatively small item in the total cost of production, and the character of the work is such that any lack of care on the worker's part is instantly detected. In such a business, final success or failure depends primarily on successful direction, and skilful buying and marketing.

If any systematic reward for increased energy is to be effective the method of calculating it should be simple and straightforward, it should be in direct proportion to the effort put forth by the worker, and it should follow quickly upon that effort. The fulfilment of these conditions is especially important where the workers are young, or when their education is very limited. They are not fulfilled in a scheme of profitsharing. Even when Labour represents a comparatively large part of the total cost of production it is doubtful how far a worker's industry throughout the year would be affected by the promise of a bonus, at some remote period, whose amount, dependent largely on circumstances over which he had no control, would in any case bear only a small proportion to the total wage.

On the whole, I think profit-sharing inadequate as a means of securing the maximum output. This can be much better done by well arranged systems of day and piece wages.

Certainly, profit-sharing might often contribute to greater harmony between Capital and Labour, but not always; for sometimes, as we have seen, owing to conditions quite beyond the control of an individual group, the profits might be greatly reduced, or disappear altogether, even when the workers had displayed exceptional devotion and diligence. In such a case, however, 
it would be very difficult to persuade a large body of men that they had not been tricked, and suspicion might be created rather than confidence.

I turn to the second way in which Labour contributes to the success of a business, namely, by suggesting new machinery or methods of working. Here the profitsharing system would fail as an incentive. It could only offer the worker who suggested some valuable improvement an equal share with all his fellow-workers in whatever part of the profits accruing from it was allocated to Labour.

'To my mind, the right way to set employees thinking how to improve machinery or methods, is to let it be generally known that suggestions would be welcomed by the management, and to give substantial immediate rewards for all suggestions adopted, graduated according to their value. I believe that British industry has lost immeasurably by failing to adopt that simple method of stimulating the latent inventive genius of employees.

But the most tempting rewards, the most skilfully adjusted system of piece rates, the most careful supervision, will not alone enable the nation to reach full industrial efficiency. At the risk of repetition I must once more emphasise the primary need for a better mutual understanding between Capital and Labour, for goodwill and candour on the part of both, and on that of the employer for a greater respect for the worker's personality.

With these we may look forward to the future of British industry not only hopefully but with full confidence. Without them it is very uncertain. 



\section{XI}

By Professor S. J. CHAPMAN, C.B.E.

IN the preparation of this book writers were asked to confine themselves to points needing particular emphasis, in their opinion, in what bears on the relations that will or should subsist between Capital and Labour after the war. Each chapter is therefore selective; and it was obviously impossible for any writer to cover the whole field of labour questions in the space at his or her command. This concluding chapter will be no exception to the rule. It is no attempt to achieve the impossible, but, like its predecessors, it will be limited to certain salient features of the outlook.

'The greatest industrial problem on the labour side after the war, as it seems to me, will be one not merely of equitable sharing in the output, but of bringing the wage-earner more vitally into relation, through his interest and sense of responsibility, with the conduct and development of production. 'This problem was outstanding before the war, and it has been strikingly accentuated as a result of the war.

There has hitherto been more or less failure to encourage workmen so to exert themselves as to get the most out of industry and aid its progress. Broadly, the reason of this failure would seem to be threefold :-

First, it has not been made evident to the workman 263 
that it is in his interests to co-operate with employers in improving and making the best of the industries of the country.

Secondly, even when it is generally allowed that the wage-earning classes as a whole would be benefited in the long run from so doing, the workman has been afraid of the immediate consequences to himself of industrial changes.

Thirdly, he has not been encouraged to give his mind to problems of industrial organisation.

These three considerations raise a number of detailed questions comnected with wages and the security of the workman's position, which will be considered in detail.

In many cases, the system of paying wages is such that it is a matter of indifference, to the short-sighted operative at any rate, whether he puts forth much or little effort. This is not so where piece-rates, or premiums based on piece-rates, are paid; but it is not feasible to arrange a satisfactory system of piece-rates-or, indeed, to have piece-rates at all-in certain industries, and the desired end, of getting the workman to do his best for the industry, cannot as a rule, I shall argue, be secured by piece-rates alone. Moreover, where piece-rates are found it not infrequently happens that rules and customs of the trade are operative which may limit their stimulating effect in a degree greater than is necessary to protect the workman against overstrain.

'The origin of these rules and customs is manifold. For one thing, they are designed to prevent discomfort at work and save the workman from being prematurely worn out. But they have been supported also out of a fear lest the demand for labour should be reduced as a result of more strenuous working, and there has been little confidence in the argument, when met with, that the value 
of labour per hour would as a rule be raised, because more work would be done in the hour. Again, the employee is apt to suspect, and unfortunately with good reason in too many instances, that greater effort on his part would be followed by such a cutting of piece-rates that in the end he would be getting little more than before, and doing much more work. And yet a third reason for such restriction of output as there is-which is generally negative rather than positive, consisting in the absence of any inclination to magnify the output-is that Trade Unions are afraid of undermining the security of their members' position in industry if they encourage an increased productivity per head. It may be contended that if each man does more, fewer men will be wanted; insufficient weight being attached to the consideration that if each man does more, the competitive strength of the industry may be so magnified that it will expand, with the result that the demand for labour of the kind in question may actually be increased. However, it would be a mistake to assume that the optimistic view is invariably the right one in this matter. It must be admitted that the security of the workman's position is at stake in some cases, and is feared to be so in a large number of cases, while the desire for security is one of the strongest motives in the ranks of laboui at the present time.

A solution of the problem is not, however, to be found merely in piece-rates, or premium systems based on piece-rates. They are not universally applicable, as has already been said, and where they are, their appeal being so exclusively individual, they fail to make full use of the influcnce which one man can exert upon another. A business usually functions as an organic whole, and more or less chaotic results would follow if the several workmen were regarded as atoms, and the pace of each 
had no relation to the pace of the whole-indeed, not uncommonly wide differences in rapidity of work in a factory are out of the question. Incentives, to produce maxima effects, must be addressed to groups, as well as to individuals, when possible, for in modern industry the group of labour is as a rule the unit. Hence the value of the group piece-rate or group premium scheme. But even this, though frequently superior to the more individualistic scheme, is defective in narrowing the reference of the workman's gain to a particular section of the work, and more or less to the status quo. He is encouraged to get the most out of his section; but he is likely to be timid about changes in method, because he may be called upon to perform unaccustomed operations; and he is not induced to take wide and long-sighted views over matters affecting the prosperity of the industry as a whole.

The question of whether it is worth while to encourage in the workman these wide and long-sighted views, has an important bearing on his apprehensions about the cutting of piece-rates and the security of his position. If wagerates have to be altered, as the result of change in productive methods, the workman is most likely to examine them to-day from the standpoint of his small corner in the industry; and not, therefore, to realise that the change may so increase the prosperity of the industry as to raise the whole level of earnings. Similarly, when a change is regarded from a narrow point of view it may seem menacing to the employee's tenure of employment, though when regarded from the wider point of view it may become apparent that his security is increased, though this is not invariably the case. It would appear to be desirable, then, that the wages system should be of such a kind as to induce the workman to regard his work from the standpoint of the industry as a whole. 
A wages system to achieve this end, that is, to lead the operative to consider the conditions and possibilities of his industry in determining his attitude to wages and working rules, would seemingly have to allocate to the workman some of the gains of increased prosperity. In other words, the wages system should be so designed as to make it clear that the wage was a share in the industry's earnings which would advance as these earnings advanced. There are few industries in which this is an understood thing, or in which the arrangements made for the readjustment of wages give effect to this idea. It must be emphasised that the prosperity intended now is not that of the individual firm, but of the industry as a whole. What is here meant is not profit-sharing in the ordinary acceptation of the term-though of course it does mean profit-sharing with the industry as a whole taken as the unit. Profit-sharing in the ordinary sense is no substitute for what has been outlined, but it is an important adjunct in the degree in which it excites the personal interest of the workman in the success of his firm, and this depends upon the possibility of a scheme of profit-sharing that creates an appreciable incentive.

The regulated slide of wages with the prosperity of the industry as a whole does not imply a system of wages fundamentally different from that which prevails at the present time. As a business becomes more lucrative, the wages paid tend to rise now; but this rise is only obtained, as a rule, after friction, which may cause cessation of work, and, in any event, leaves results that militate for a time against the efficiency of production. All that is suggested is that there should be understandings and arrangements to enable changes in wages to take place more easily and without this friction-which is 
damaging to the community both productively and socially - or, at least, with diminished friction. Whether in any particular instance the wage should slide with the cyclical movements of trade, is a matter for discussion. One advantage of its doing so is that participation in good fortune and the reverse is then made more prominent, and there is the additional recommendation that some unemployment in bad times, and over-trading in good times, would be stopped. In any plan for varying wages, some standard wage would, of course, have to be recognised as the bottom limit.

Sliding-scales were an attempt to give effect to this idea of making weekly wages move with the prosperity of an industry. But they were defective in many ways, and frequently failed to achieve the desired end, while, evidently, they are not appropriate to all industries. It must be admitted at once that it would be impossible to devise a scheme under which wages would automatically follow the industry's success; and, incidentally, it must be noted that the quantity of output per head is not a perfectly reliable index of this, seeing that success might be due to improved prices consequent upon improved quality. Any arrangements that were made would necessarily have to be of an elastic kind and vary with the industry; what would be common to all of them would be an understanding that the wages were to be regarded in this way, that is to say, an understanding that the greater prosperity of the industry should be accompanied by an increase of wages-rates.

'The best and most elastic plan night be to have wages and conditions of labour, including 'Trade Union rules and demarcation agreenents, periodically reviewed in each industry by a joint council of masters and men. Joint committees are already in existence in many 
industries, but most have the defect of not providing for a periodic examination of the scheme of work and wages; and there appears to be a disposition among some people to regard the party which more or less frèquently raises the question of readjustments as a disturber of the public peace, the implication being that when a settlement was reached it should be a more or less permanent settlement. It is in the nature of things, wherever there is progress, however, that the settlement which is satisfactory for the time being should soon become obsolete. And it is in the interests of employers as well as of the workpeople to make revisions when an industry could bear higher wages. When wages cease to be commensurate with an industry's earnings, a brake tends to be put upon it in a thousand and one trifling ways, all of which are not deliberately intended, some being unconscious reactions. Moreover, it commonly happens that when a case for readjusting wages contains as an integral part a case for reorganising the work, these two questions are best discussed together. Yet the prevailing notion to-day seems to be that the party which moves for change is more or less making a threat, and the chances are that it will have to fight to get what it wants. This is unfortunate, and creates an appearance of conflict of interest where there may be none. Readjustments should be regarded as natural and necessary; and probably it could be secured that they should be so regarded by a system of, say, yearly revisions of the whole situation. Difficulties in the way of revision might, of course, be found in insufficiency of information : but in the last twenty-five years this defect has been considerably repaired by the extension of the joint-stock system, the publication of results and the general spread of information; and, where the needful evidence was imperfect, the committees would in time arrange for the 
continuous record of things bearing on the matters requiring settlement.

It is sometimes said that wages should be regulated by the cost of living. 'This proposal must be examined with reference (1) to normal circumstances, and (2) to such exceptional circumstances as we have now, and shall have after the resumption of peace. As regards normal circumstances, the proposal would only secure a part of what is wanted, and that part is commonly covered by the slide of wages with the prosperity of an industry. For a rise of the cost of living always means, in normal circumstances, a rise in prices generally; and a rise in the prices of the output of an industry would mean an increase in its general prosperity. Consequently, the slide of wages with the prosperity of an industry secures, ordinarily; some slide of wages with the cost of living. And it secures more than this, namely, a rise of wages when there is no ascent in the cost of living, though there is an increase in the gains of the industry. 'Thus prices might fall all round in consequence of greater productivity, and the slide of wages with the cost of living would then mean that wages should fall. But, as a matter of fact, the industry might be more lucrative, because the enlarged output due to the greater productivity might more than make up for the fall in prices, and profits might be materially augmented.

Nevertheless, it may be necessary in exceptional circumstances to provide for some direct variation of wages with the cost of living; and we should not be unprepared for such exceptional circumstances at the close of the war. Soon after hostilities cease, general prices will undoubtedly decline. This will be due not so much to the removal of the war demand for goods and 
services-since the gap created by the removal of this war demand will probably be filled to a substantial extent by demands arising from limited consumption during the war, the deferment during the war of repairs and renewals, replacements necessitated by the damage of the war and the reaccumulation of the world's stocks - as by the return to nore normal conditions in the matter of the currency and the financing of business. It is impossible to say now to what level prices will subside, or how long the subsidence will take. Much depends on the action of the Government; for instance, the financing of industry by banks might be carried a long way under Government support. Again, gold circulating currency might be restored, and it might not. If it were, prices would reach a lower level than if it were not: because a larger volume of purchasing-power can be maintained when all the gold is in the reserve than when a part of it is circulating as currency; and, of course, the level of prices depends on the volume of purchasing-power. But, whatever the action of the Government, we may feel assured that a notable fall in prices, which might be delayed for a time, is bound to be experienced. This being so, it is evident that the money wages that could only just be paid at first, would soon become an impossibly heavy charge, unless something occurred to render the amount left for wages, after payment of capital, much greater than it was before the war. If the problem of industrial organisation is approached by employers and employees in an open-minded way, with the desire to minimise as much as possible any real or seeming conflict of interest, and with the object of increasing the yield of the industries of the country, productivity will be raised to a substantial extent. Productivity may not be raised rapidly, however, though whole-hearted effort on the part of employers and 
operatives to improve the efficiency of industry would certainly yield eventually far more comfortable real incomes for the latter than they had before the war.

This matter of money wages in the exceptional period just after the war requires most careful consideration, and evidently industry by industry, because war bonuses have varied greatly from industry to industry. It is a special question, however, which must not now be allowed to keep us longer from the general problems here under discussion.

Returning, then, to the main thread of our argument, we observe at once that another, and perhaps the most weighty, reason why the working classes have co-operated imperfectly with the management on the constructive side of industry, is that they have not been led to take an interest in organisation. Sharing only indirectly, insignificantly, and on sufferance, in workshop control, they naturally tend to regard all matters of organisation as the real business of somebody else, in which they have no immediate concern, and even perhaps as something to resist as it is imposed upon them. One of the most important ways of leading the workman to realise the importance of workshop organisation, aid in its improvement and make it work at its best, would appear to be to co-operate with him, in some degree, in its design and direction. Every person has naturally an interest in that for which he is in part responsible. At the present time, so-called "scientific" management is generally opposed by the wage-earners, but provided that some control is given to them, and that working-class interests are properly safeguarded, there should be few difficulties in its way.

It is obvious that the problem of the degree and kind of control to be exercised by the operatives, in association with the management, is by no means an easy one to 
solve, and is not the same for all industries. But it seems as obvious that a great deal of authority could be vested in joint councils of masters and men, and workshop committees; and it seems not unlikely that it would be both feasible and desirable to consult with representatives of the workpeople even on matters that could not be handed over to such bodies. The question is not one of sentiment merely, but of good business, for the operative should be exceedingly helpful in making suggestions about his everyday work and the everyday conduct of the factory, as he is constantly in touch with both, and intimately aequainted with them, as a manager cannot be; and the psychological reactions to be expected are bound to be of productive value, because a person is more likely to work in the right spirit within a system with which he identifies himself, and which he has helped to shape. There seems to be no doubt that in most works the best has not hitherto been made of the means of production. More eareful study is requisite, both of the adaptation of means to ends, and of the human agent, particularly with reference to the fatigue arising from different systems of work, and the relation of incentives to different systems of pay. The certain result would be considerable modification of existing schemes, and variations in arrangements from time to time; and it is difficult to see how the extensive changes entailed could be carried through, and how the goodwill of the workman could be assured, if in some way the wage-earning classes were not brought in some degree-largely, it might be, in an advisory capacity-into the control of industrial operations.

A point that is not uncommonly overlooked is that one of the most insistent demands of the wage-earning classes is for security both of employment and wages. 
This strong desire for security lies at the root of many 'Trade Union regulations. Some workpeople restrict entrances to their trade, not primarily with the object of making their trade a monopoly and enabling them to get excessive wages, but chiefly with the intention of preventing people from being trained to take their places before they are forced by old age or invalidity to surrender them. Similarly, regulations relating to the proportion of labour to machinery (so far as their purpose is not to suppress overwork, and so far as they are not founded on the false theory of wages which teaches that wages must rise as the work done is limited) are to be explained in part by the operative's determination to keep himself safe in his position by putting it outside the power of the employer to dispense with his labour and substitute machinery for it.

If a freer hand is to be given to the control of industrial organisation (in which, in some fashion, representatives of the work people might be incorporated), in order to render production more efficient and adapt it from time to time to new ideas, it is certainly essential that the question of the security of tenure of the workman and the continuity of his wages should be faced. As it is admitted that many of the Trade Union regulations which have these ends in view are an impediment to industry, the statesmanlike course would seem to be to consider whether their object could not be attained in some other way which would prove less hampering or not hampering at all. 'The workman might be granted the security he desires-and more than he gets now-by concessions which would mean a small thing to businesses in comparison with the gain that would be derived from greater elasticity of system. Thus, it might be understood that arbitrary dismissals should cease; that the removal of 
a man from one job to another in the course of reorganisation should not mean loss to him in wages; and that he should not be dispensed with to his damage to make room for cheaper labour even if the cheaper labour were procurable. But the possibilities are too many for discussion here, and they obviously vary with the industry, and need, for their consideration, the experience gained from industrial practice. It is sufficient now to draw attention to the fact that the claim for security is one of the largest factors in the problem of industrial reconstruction; to notice that security does not inevitably imply continuity of employment in any particular business ; and to remind ourselves that, as businesses introducing improvements are expanding at the same time more frequently than not, reduction in the numbers employed is not entailed as the regular thing. The fundamental idea to grasp is this: if the workman is to realise his responsibilities to his industry, his industry must recognise him as having been or continuing to be an integral part of itself, and realise that to safeguard his interests is one of its chief obligations.

The notion of joint industrial councils and workshop committees, so far as they are not merely advisory, is to delegate to bodies constituted of representatives of the workpeople and the management, such parts of control as can be absolutely or conditionally handed over. The selection of the matters that could be transferred in this way would not, of course, be easy. They would not necessarily be the same in all industries, and it would be desirable to proceed experimentally. Evidently, however, with regard to some questions, the authority conferred on the workshop committees and joint councils need not be absolute. 'Thus, in certain respects they may act as controlling bodies, and in other respects as advisory. As it has already been remarked, their value would lie 
not merely in their effect on the men's attitude to the problems of the industry, but also in the fact that the workman may be expected to make valuable suggestions from time to time out of his everyday experience. Moreover, the control exercised by these bodies would not be incompatible with the representation of labour in the higher management of a business, where it seemed advisable to have profit-sharing and control-sharing in some degree. On the contrary, the one would tend to prepare the way for and lead up to the other.

There are few, if any, existing organisations for the joint and continuous consideration of trade matters, if emphasis be laid on the word "continuous." For the continuous consideration of industrial problems, including those of wages, it would seem essential that representative boards should meet periodically. On the occasions when demands from either party did not constitute the chief business, the minds of the members would be free to deal with the problems of the industry in an unprejudiced and unimpassioned way ; and consultation at stated intervals would tend to keep the workshop system in correspondence with the requirements of the industry, and make room for new methods. 'There is the fear, of course, that regular sessions might give rise at first to periodic disturbance, one party or the other always inclining to' seize the opportunity to snatch some small gain. 'This is a real danger, and unless experience showed that restraint was exercised, the value of periodic meetings would be counteracted.

No further pleading seems called for in support of the contention that it is highly desirable somewhat to remodel industrial government so as to provide for the constant consideration of trade matter's by employers and employed. Each trade might now be induced to determine for itself, at representative meetings of employers and operatives, 
the degree in which principles agreed upon as generally satisfactory could be applied to their industry, and the machinery that would be necessary. It is not likely that a common design would suit all industries, but one would expect to find identity in the underlying ideas of the schemes adopted.

In the furtherance of preliminary and later discussions, and in the avoidance of the strikes or lock-outs that might follow a breach of negotiations, the State could be of incalculable assistance. It is questionable, however, whether under English conditions it would be advisable for it to act in any other way than as a mediator, or in an advisory capacity. 'The most satisfactory results are likely to arise from the determination of its own destiny by each industry for itself at representative meetings. But the most perfect machinery for the settlement of labour questions is not always capable of producing agreement, and it may suddenly generate friction which brings it to a standstill. In such cases of failure, experience shows that the State can frequently prevent cessation of work, and secure mutually satisfactory results, by arranging for the resumption of discussion, and itself, through its representatives, directing it and advising. It is exceedingly unlikely that the determination of wages and conditions of work by the State would be appropriate in a highly complex industrial system, in which each industry has its own peculiar problems and difficulties, requiring for their complete understanding practical contact with them. This is not, of course, to condemn State action to secure a minimum wage, or even a reasonable standard wage in an unorganised industry, and better conditions of work.

The saving clause terminating the preceding paragraph suggests that some qualification may be needed if 
the conclusions reached above are to be regarded as applying throughout industry. What has been said so far has reference mainly to the organised trades, as they might be called, in which trade unionism is strong and employers have already shown themselves capable of taking concerted action; and it might be objected that the general ideas laid down imply a degree of organisation that is not now to be found, and cannot suddenly be created, in the least developed trades.

'This objection is well founded with reference to what is immediately practicable, but it is worth while considering also what is ultimately attainable, and it requires no great prophetic insight to foresee that progress will eventually assimilate the unorganised to the organised trades. Moreover, even as things are in certain industries, arrangements foreshadowing the ideal are possible. In the so-called sweated industries there are the Wages Boards, which might be given extended powers: they stand for the popular control of production in a restricted measure, if not in any high degree for representative government. Again, there are industries intermediate between the most and least advanced, in which something combined of the Wages Board and a joint representative body would suit conditions best; and even in the most mature industries there may be sections requiring the dictation of a Wages Board. Thus, in various degrees and ways, according to circumstances, may control be popularised, with advisory and more authoritative duties combined in different proportions, and with more or less co-operation on the part of the State. But, broadly, the probability would seem to be that the higher the stage of organisation of the trade on its human side, the further could the machinery for representing workingclass interests be effectively extended, so that influential 
workshop committees would not commonly be found where adequately representative joint councils did not exist.

This completes a fugitive and impressionistic sketch of what appears to the writer, in view of the labour claims to which the greatest weight is now attached, to be the line of least resistance for industrial progress to take, and one to be recommended also on the ground that it should lead both to greater efficiency and more contentment. It must not be supposed, however, that the matter dealt with embraces everything which, in shaping our future, we should keep in view. Democracy may be the right form of government for civilised beings, but it may be misled by the wrong ideals and misguided in its choice of means. Sinilarly, the industrial system may be soundly constituted in providing suitably for the expression of the human interests involved, but it may go astray in the decisions actually taken. One essential point is that social and industrial arrangements should furnish opportunities to the most capable, and this is apt to be passed over at times because its obvious benefit is confined to the few, while the immense advantages that result all round, through the maintenance of a high level of vitality in production and the surer guarantees of intelligent direction, too easily escape notice. Here we have but one example of the many considerations, not treated in this chapter, which enter into the complex labour problem. Reference is made to them as a caution against envisaging the labour problem as much simpler than it is. And, with reference to the matters that have been discussed, it will be as well to strike again the note of warning. Though the most promising path to choose happens to be the one of least resistance, in the opinion of many competent authorities it will be by no means easy to tread without stum- 
bling and without incurring unfortunate delays. We shall only be prosperous in following it, if both sides cultivate a suspicion of extremes, and determine to be open-minded, compromising, and forbearing. Moreorer, we must make it clear to ourselves at the outset that we cannot afford any sacrifice of initiative and enterprise, and that the men who are leading and can lead and plan to the best effect must not be constantly hampered and discouraged by cavilling criticism and trivial opposition for little more than paper gains. Similarly it would be a bad mistake on the other side to make a mountain of a mole-hill in estimating the disadvantages of some course that was strongly desired by the operative classes. Altogether, it cannot be denied that to achieve the best we must learn to be wiser than we have been.

The above discussion has been kept on the economic plane because it is on this plane that the concrete problems before us will be met with and have to be dealt with. But the claims and expectations of which some account has bcen given here have roots that run deeper into the social system. They originate in a recognition of greater solidarity, which was growing rapidly before the war and has since been accentuated and become more articulate. A social structure bound together by serfiom is a ramshackle creation at best, devoid of any internal principle of cohesion. 'This is now far behind us, but the bare wages system repeats many of its inherent defects. At the other extreme, to which the civilisation for which the Allies stand is working, lies the ideal of self-determination. In this, the ruling authority is not acquired by force, but is won by efficient leadership and the acceptance of responsibilities that go far beyond wages and profits concepts and the most obvious humani- 
tarian obligations. Moreover, it is being increasingly borne in upon us that it is an authority which is not and should not be wholly centralised in the employer. To some extent it must be divided and distributed according to the capacities of the several human parts of the industrial organism to think and act wisely for more than personal objects; while, so far as it is centralised, it is and must be sustained and fortified by ready co-operation, and guided in some degree by the counsel of the directed units, which, through their organisation, have lost their character of isolated atoms. In short, a soulless machine is being transformed into a vital organism which is made a unity by the public-spirited volition of its parts, and is driven, not solely from the manager's office, but also by the emotional forces of its constituents, whose action is tending to be less narrowly self-interested and more convergent on a common end. It goes without saying that the ideal is not yet at hand; but it is much to be able to affirm that it is envisaged and sought, while the conditions of its complete realisation are being more firmly grasped. For ultimate success, lengthy preparation, through extended and improved education and tentative experiments in industrial government and self-discipline, are requisite. Indeed, so imperfectly are we trained for economic democracy-which, properly conceived, by no means entails the suppression of private adventure and competition - that it is impossible as yet, in concrete terms, to define our future in any detail. That it will be complex and variable may be assumed, in view of the diversity of human tastes and powers and the multitude of orerlapping human interests in relation to which organisation has a place. But it is possible to indicate the spirit and abstract mould of the system to which present tendencies are leading. 
The transition began long ago, and for the most part it has not been a peaceful process. On the one side, its end was only dimly conceived, or even misconceived, with the result that a needlessly aggressive attitude was too often assumed; while, on the other side, it was as frequently misconstrued, and so generally viewed with alarm that opposition was the rule. It is to be hoped that by now we have learnt to see things more as they are and in due proportion, and to be less class-conscious. But it is easy to trust too much and resolve too little. We have still to endure the final strain of a titanic effort, and the wear and tear may leave us prone to irritations and misunderstandings. Moreover, checks and anxieties may beset the restoration of civilian conditions, and we shall become more conscious of the financial burden associated with the country's great endeavour when the exertion of that endeavour, with its constant excitements, is behind us. It would be well to bear this in mind, and determine, while our judgment is still unflawed, to act as reason and sentiment now dictate, lest reconstruction be damaged at its foundations and a great opportunity be cast away. 


\section{APPENDIX}

FIRST REPORT OF THE COMMITTEE OF THE MINISTRY OF RECONSTRUCTION ON RELATIONS BETWEEN EMPLOYERS AND EMPLOYED.

To the Rt. Hon. D. Lloyd George, M.P., Prime Minister.

$\mathrm{Srk}$,

WE have the honour to submit the following Interim Report on Joint Standing Industrial Councils.

2. The terms of reference to the Sub-Committee are :-

"(1) To make and consider suggestions for securing a permanent improvement in the relations between employers and workmen.

"(2) To recommend means for securing that industrial conditions affecting the relations between employers and workmen shall be systematically reviewed by those concerned, with a view to improving conditions in the future."

3. After a general consideration of our duties in relation to the matters referred to us, we decided first to address ourselves to the problem of establishing permanently improved relations between employers and employed in the main industries of the country, in which there exist representative organisations on both sides. The present report accordingly deals more especially with these trades. We are proceeding with the consideration of the problems connected with the industries which are less well organised.

4. We appreciate that under the pressure of the war hoth 273 
employers and workpeople and their organisations are very much pre-occupied, but, notwithstanding, we believe it to be of the highest importance that our proposals should be put before those concerned without delay, so that employers and employed may mcet in the near future and discuss the problems before them.

5. The circumstances of the present time are admitted on all sides to offer a great opportunity for securing a permanent improvement in the relations between employers and employed, while failure to utilise the opportunity may involve the nation in grave industrial difficulties at the end of the war.

It is generally allowed that the war almost enforced some reconstruction of industry, and in considering the subjects referred to us we have kept in view the need for securing in the development of reconstruction the largest possible measure of co-operation between employers and employed.

In the interests of the community it is vital that after the war the co-operation of all classes, established during the war, should continue, and more especially with regard to the relations between employers and employed. For securing improvement in the latter, it is essential that any proposals put forward should offer to workpeople the means of attaining improved conditions of employment and a higher standard of comfort generally, and involve the enlistment of their active and continuous co-operation in the promotion of industry.

To this end, the establishment for each industry of an organisation, representative of employers and workpeople, to have as its object the regular consideration of matters affecting the progress and well-being of the trade from the point of view of all those engaged in it, so far as this is consistent with the general interest of the community, appears to us necessary.

6. Nany complicated problems have arisen during the war which have a bearing both on employers and workpeople, and may affect the relations between them. It is clear that industrial conditions will need careful handling if grave difficulties and strained relations are to be avoided after the war has ended. The precise nature of the problems to be faced naturally varies from industry to industry, and even from branch to branch within the same industry. Their treatment consequently will need an intimate knowledge of the facts and circumstances 
of each trade, and such knowledge is to be found only among those directly connected with the trade.

7. With a view to providing means for carrying out the policy outlined above, we recommend that His Majesty's Government should propose without delay to the various associations of employers and employed the formation of Joint Standing Industrial Councils in the several industries, where they do not already exist, composed of representatives of employers and employed, regard being paid to the various sections of the industry and the various classes of labour engaged.

8. The appointment of a Chairman or Chairmen should, we think, be left to the Council, who may decide that these should be--

(1) A Chairman for each side of the Council ;

(2) A Chairman and Vice-Chairman selected from the members of the Council (one from each side of the Council);

(3) A Chairman chosen by the Council from independent persons outside the industry; or

(4) A Chairman nominated by such person or authority as the Council may determine or, failing agreement, by the Government.

9. The Council should meet at regular and frequent intervals.

10. The objects to which the consideration of the Councils should be directed should be appropriate matters affecting the several industries, and particularly the establishment of a closer co-operation between employers and employed. Questions connected with demobilisation will call for early attention.

11. One of the chief factors in the problem, as it at first presents itself, consists of the guarantees given by the Government, with Parliamentary sanction, and the various undertakings entered into by employers, to restore the Trade Union rules and customs suspended during the war. While this does not mean that all the lessons learnt during the war should be ignored, it does mean that the definite co-operation and acquiescence by both employers and employed must be a condition of any setting aside of these guarantees or undertakings, and that, if new arrangements are to be reached, in themselves more satisfactory to all parties but not in strict accordance with the guarantees, they must be the joint work of employers and employed. 
12. The matters to be considered by the Councils must inevitably differ widely from industry to industry, as different circumstances and conditions call for different treatment, but we are of opinion that the suggestions set forth below ought to be taken into account, subject to such modification in each case as may serve to adapt them to the needs of the various industries.

13. In the well-organised industries, one of the first questions to be considered should be the establishment of local and works organisations to supplement and make more effective the work of the central bodies. It is not enough to secure co-operation at the centre between the national organisations; it is equally necessary to enlist the activity and support of employers and employed in the districts and in individual establishments. The National Industrial Council should not be regarded as complete in itself ; what is needed is a triple organisation-in the workshops, the districts, and nationally. Moreover, it is essential that the organisation at each of these three stages should proceed on a common principle, and that the greatest measure of common action between them should be secured.

14. With this end in view, we are of opinion that the following proposals should be laid before the National Industrial Councils :-

(a) That District Councils, representative of the Trade Unions and of the Employers' Association in the industry, should be created, or developed out of the existing machinery for negotiation in the various trades.

(b) That Works Committees, representative of the management and of the workers employed, should be instituted in particular works to act in close co-operation with the district and national machinery.

As it is of the highest importance that the sclieme making provision for these Committees should be such as to secure the support of the Trade Unions and Employers' Associations concerned, its design should be a matter for agreement between these organisations.

Just as regular meetings and continuity of co-operation are essential in the case of the National Industrial Councils, so they seem to be necessary in the case of the district and works organisa- 
tions. The object is to secure co-operation by granting to workpeople a greater share in the consideration of matters affecting their industry, and this can only be achieved by keeping employers and workpeople in constant touch.

15. The respective functions of Works Committees, District Councils, and National Councils will no doubt require to be determined separately in accordance with the varying conditions of different industries. Care will need to be taken in each case to delimit accurately their respective functions, in order to avoid overlapping and resulting friction. For instance, where conditions of employment are determined by national agreements, the District Councils or Works Committees should not be allowed to contract out of conditions so laid down, nor, where conditions are determined by local agreements, should such power be allowed to Works Committees.

16. Among the questions with which it is suggested that the National Councils should deal or allocate to District Councils or Works Committees, the following may be selected for special mention :-

(i.) The better utilisation of the practical knowledge and experience of the workpeople.

(ii.) Means for securing to the workpeople a greater share in and responsibility for the determination and observance of the conditions under which their work is carried on.

(iii.) The settlement of the general principles governing the conditions of employment, including the methods of fixing, paying, and readjusting wages, having regard to the need for securing to the workpeople a share in the increased prosperity of the industry.

(iv.) The establishment of regular methods of negotiation for issues arising between employers and workpeople, with a view both to the prevention of differences, and to their better adjustment when they appear.

(v.) Means of ensuring to the workpeople the greatest possible security of earnings and employment, without undue restriction upon change of occupation or employer.

(vi.) Methods of fixing and adjusting earnings, piecework prices, \&c., and of dealing with the many difficulties which arise with regard to the method and amount of payment 
apart from the fixing of general standard rates, which are already covered by paragraph (iii.).

(vii.) Technical education and training.

(viii.) Industrial research and the full utilisation of its results.

(ix.) The provision of facilities for the full consideration and utilisation of inventions and improvement designed by workpeople, and for the adequate safeguarding of the rights of the designers of such improvements.

(x.) Improvements of processes, machinery and organisation and appropriate questions relating to management and the examination of industrial experiments, with special reference to co-operation in carrying new ideas into effect and full consideration of the workpeople's point of view in relation to them.

(xi.) Proposed legislation affecting the industry.

17. The methods by which the functions of the proposed Councils should be correlated to those of joint bodies in the different districts, and in the various works within the districts, must necessarily vary according to the trade. It may, therefore, be the best policy to leave it to the trades themselves to formulate schemes suitable to their special circumstances, it being understood that it is essential to secure in each industry the fullest measure of co-operation between employers and employed, both generally, through the National Councils, and specifically, through district Committees and workshop Committees.

18. It would seem advisable that the Government should put the proposals relating to National Industrial Councils before the employers' and workpeople's associations and request them to adopt such measures as are needful for their estabiishment where they do not already exist. Suitable steps should also be taken, at the proper time, to put the matter before the general public.

19. In forwarding the proposals to the parties concerned, we think the Government should offer to be represented in an advisory capacity at the preliminary meetings of a Council, if the parties so desire. We are also of opinion that the Government should undertake to supply to the various Councils such information on industrial subjects as may be available and likely to prove of value. 
20. It has been suggested that means must be devised to safeguard the interests of the community against possible action of an anti-social character on the part of the Councils. We have, however, here assumed that the Councils, in their work of promoting the interests of their own industries, will have regard for the National interest. If they fulfil their functions they will be the best builders of national prosperity. The State never parts with its inherent over-riding power, but such power may be least needed when least obtruded.

21. It appears to us that it may be desirable at some later stage for the State to give the sanction of law to agreements made by the Councils, but the initiative in this direction should come from the Councils themselves.

22. The plans sketched in the foregoing paragraphs are applicable in the form in which they are given only to industries in which there are responsible associations of employers and workpeople which can claim to be fairly representative. The case of the less well-organised trades or sections of a trade necessarily needs further consideration. We hope to be in a position shortly to put forward recommendations that will prepare the way for the active utilisation in these trades of the same practical co-operation as is foreshadowed in the proposals made above for the more highly-organised trades.

23. It may be desirable to state here our considered opinion that an essential condition of securing a permanent improvement in the relations between employers and employed is that there should be adequate organisation on the part of both employers and workpeople. The proposals outlined for joint co-operation throughout the several industries depend for their ultimate success upon there being such organisation on both sides; and such organisation is necessary also to provide means whereby the arrangements and agreements made for the industry may be effectively carried out.

24. We have thought it well to refrain from making suggestions or offering opinions with regard to such matters as profit-sharing, co-partnership, or particular systems of wages, etc. It would be impracticable for us to make any useful general recommendations on such matters, having regard to the varying conditions in different trades. We are convinced, moreover, that a permanent improvement in the relations between 
employers and employed must be founded upon something other than a cash basis. What is wanted is that the workpeople should have a greater opportunity of participating in the discussion about and adjustment of those parts of industry by which they are most affected.

25. The schemes recommended in this Report are intended not merely for the treatment of industrial problems when they have become acute, but also, and more especially, to prevent their becoming acute. We believe that regular meetings to discuss industrial questions, apart from and prior to any differences with regard to them that may have begun to cause friction, will materially reduce the number of occasions on which, in the view of either employers or employed, it is necessary to contemplate recourse to a stoppage of work.

26. We venture to hope that representative men in each industry, with pride in their calling and care for its place as a contributor to the national well-being, will come together in the manner here suggested, and apply themselves to promoting industrial harmony and efficiency and removing the obstacles that have hitherto stood in the way.

We have the honour to be, Sir,

Your obedient Servants,

J. H. Whitley, Chairman.

F. S. Button.

Geo. J. Carter.

S. J. Chapman.

G. H. Clavghton.

J. R. Clynes.

J. A. Hobson.

A. Susan Lawrence.

J. J. Mallon.

Thos. R. Ratcliffe-Ellis.

Robt. SMillie.

Allan M. Smith.

Mona Wilson.

8th Warch 1917. H. J. WILson,
Arthur GreEn wood, Secretaries. 


\section{BO0KSonAFTER-WAR PROBLEMS}

\section{THE GREAT PROBLEMS OF BRITISH}

STATESMANSHIP.

By J. ELLIS BARKER, Author of " Modern Germany," "Great and Greater Britain," etc. 10s. 6d. net A consideration of the principal problems of foreign domestic and economic policy with which British statesmanship will have to deal both at the Peace Congress and afterwards.

\section{GERMANY'S ANNEXATIONIST AIMS.}

By S. GRUMBACH. Translated, Abbreviated and Introduced by $\mathrm{J}$. Ellis Barker.

3s. 6d. net

A comprehensive statement of Germany's annexationist aims, giving the demands of the leading German rulers, statesmen, politicians, professors, generals, business men and publicists. Separate chapters deal with Germany's aims regarding Belgium, France, Russia, the British Empire, Turkey, the Far East, America, the World.

THREE GENTURIES OF TREATIES OF PEACE AND THEIR TEACHING.

By the Rt. Hon. Sir W. G. F. PHILliMORE, Bart., D.C.L., LL.D., late Lord Justice of Appeal. 7s. 6d. net

The object of this book is to supply materials for guidance and warning when the terms of the future Peace come to be settled.

THE WAR AND THE NATION. A Study in Constructive Politics.

By W. C. D. WHETHAM, F.R.S.

6s. net

This timely volume contains a critical account of some recent enquiries into national organisation and a consideration of the subject from a single point of view.

\section{THE AWAKENING OF AN EMPIRE.}

BY ROBERT GRANT WEBSTER. 6s, net "Mr. Webster's book is eminently sane, sound, and twell argued."-Daily Telegraph.

THE NEW EMPIRE PARTNERSHIP : Defence, Commerce, Policy.

BY PERCY and ARCHIBALD HURD.

6s. net

"The authors of this work have chosen an excellent and business-like title for an excellent and business-like work. . . . It is fresh, forcible, readable, excellently docuinented and marshalled. It suggests rather than dictates." - The Spectator.

JOHN MURRAY, Albemarle Street, LONDON, W. 


\section{BOOKS ON THE WAR}

INSIDE CONSTANTINOPLE.

During the Dardanelles Expedition. A Dlplomatist's Diary, April to September, 1915. By LEWIS EINSTEIN, former Minister Plenipotentiary, U.S. Diplomatic Service, late Special Agent at the American Embassy.

6s. net

\section{TWENTY -TWO MONTHS UNDER FIRE.}

By Brigadier-General HENRY PAGE CROFT, C.M.G., M.P. With Maps.

5s. net The record of a Member of Parliament who joined his Territorial regiment on the outbreak of war, and took a long and continuous part in the fighting, including every one of the British offensives until the end of the Somme.

\section{THE INDIAN GORPS IN FRANCE.}

By Lt.-Col. J. W. B. MEREWETHER, C.I.E., and the Rt. Hon. Sir FREDERICK SMITH. Illustrated. 10s. 6d, net

This history is dedicated by permission to His Majesty the King-Emperor, and published under the authority of His Majesty's Secretary of 'State for India in Council.

\section{GAPTIVITY AND ESCAPE.}

By M. JEAN MARTIN. Translated from the French. The Narrative of a French Sergeant-Major, who was captured in the early days of the war, was confined in German prisons and made a remarkable escape.

5s. net

BY FREDERICK PALMER.

WITH OUR FACES IN THE LIGHT. 2s. 6d. net A stirring message of patriotism by a distinguished American, who hopes that it may explain to Britons America's spirit in this war.

WITH THE NEW ARMY ON THE SOMME. My Second Year of the War. 6s, net

"He knows just how to weave the personal thread into his story of great battles."-Daily Chronicle.

MY YEAR OF THE WAR. Fourth Impression. 6s. net Including an Account of Experiences with the Troops in France, and the Record of a Visit to the Grand Fleet, which is here given for the first time in its complete form.

JOHN MURRAY, Albemarle Street, LONDON, W. 


\section{WORKS BY J. ELLIS BARKER}

\section{MODERN GERMANY}

HER POLITICAL AND ECONOMIC PROBLEMS, HER AMBITIONS, AND THE CAUSES OF HER SUCCESSES AND HER FAILURES.

5 th very greatly Enlarged Edition

7s. 6d. net.

"We are always glad to welcome what may be called a bird's-eye view of the conditions prevailing in continental countries, and this must be especially the case with regard to Germany. . .. Much useful information is contained in these pages."-The Spectator.

\section{THE FOUNDATIONS OF GERMANY}

A DOCUMENTARY ACCOUNT REVEALING THE CAUSES OF HER STRENGTH, WEALTH, AND EFFICIENCY.

7s. 6d. net.

"It would be difficult to overrate the value of Mr Barker's work. I know of no other man, living or dead, who has so effectively drawn aside the curtain that conceals from the English-speaking people the naked truth about the Hohenzollern and his subjects."-Referee.

\section{GREAT AND GREATER BRITAIN}

THE POLITICAL, NAVAL, MILITARY, INDUSTRIAL, FINANCIAL, AND SOCIAL PROBLEMIS OF THE MOTHERLAND AND EMPIRE. 2nd and Enlarged Edition

10s. 6d. net.

"A work so comprehensive must necessarily touch a multitude of points of controversy ; but few persons interested in the subject could read it without learning something and having their ideas cleared."-The Scotsman.

\section{BRITISH SOCIALISM}

AN EXAMINATION OF ITS DOCTRINES, POLICY, AIMS, AND PRACTICAL PROPOSALS.

10s. 6d. net.

"No review could do justice to this admirable book; the reader should buy or borrow it and study it for himself. It bears directly on almost every problem of modern legislation and of modern life."-The Daily Mail.

JOHN MURRAY, ALBEMARLE STREET, LONDON, W. 1 


\section{Works on Economics छ̊ Politics}

\section{THE RISE AND DECLINE \\ OF THE NETHERLANDS}

A POLITICAL AND ECONOMIC HISTORY.

By J. ELLIS BARKER

10s. 6d. net.

"There is nothing in any language like it, and when all is said it remains one of the most striking additions recently made to the political library."-Mr J. L. Garvin, in the Fortnightly Reviezu.

\section{SIX YEARS OF POLITICS (I 9 I $0-16$ )}

SPEECHES ON FINANCE, FOREIGN AFFAIRS, HOME RULE, AND WOMEN'S SUFFRAGE.

By D. M. Mason, M.P.

3s. 6d. net.

\section{OUR MONEY AND THE STATE}

By Hartley Withers

3s. net.

"It should be read at once by every taxpayer. Mr Withers' latest book can be most heartily commended. It is delightfully written, with never a dull page."-Morning Post.

\section{STATE SERVICES}

By George RADFord, M.A.

3s. 6d. net.

"Mr Radford's presentation is lucid, well-documented, and written in a style which, were he a Scot, other reviewers than ourselves would immediately describe as pawky."-The Nerw Statesman.

JOHN MURRAY, ALBEMARLE STREET, LONDON, W. 1 


\section{Works on Economics \& Politics}

\section{THE COMING WAR}

By Ambrose Poynter

3s. 6d. net.

Deals especially with the inevitable industrial conflict as it affects Great Britain and her Dominions; and contains valuable and striking suggestions as to the best methods of preparing to meet new conditions. The author is particularly well qualified to deal with the subject, both from long and careful study, and from a wide personal knowledge of the conditions of life and trade in both the Old and New Worlds.

\section{PRINCIPLES AND METHODS OF TAXATION}

By G. Armitage Siith, M.A., D. Lit. 2s. 6d. net.

The object of this work is to present in a concise and simple form an account of the British system of taxation and the principles on which it is based, together with some of the leading historical facts in its evolution.

\section{ZIONISM AND THE JEWISH FUTURE}

By various writers. Edited by $H$. SACHER 2s. 6d. net.

"All the more timely because one of the consequences of the war will almost certainly be that the whole Jewish question will have to be approached under auspices which differ widely from those which have hitherto obtained." - The Spectator.

"A vast amount of thought and fact very well expressed."Daily Telegraph.

JOHN MURRAY, ALBEMARLE STREET, LONDON, W. 1 
MR HARTLEY WITHERS' BOOKS ON

\section{FINANCIAL SUBJECTS}

\section{Stocks and Shares}

$4^{\text {th }}$ Impression

Cheaper. Edition, 3s. 6d. net.

7s. 6d. net.

"It is a good book, it is sure of its public, and if the laymen who read it will only follow Mr Withers' advice more than one 'bucketshop ' will be closed till further notice."-Morning Post.

\section{Money Changing}

AN INTRODUCTION TO FOREIGN EXCHANGE. 3rd Edition

3s. 6d. net.

The Financial News in a three-column review says: "Mr Withers makes the topic interesting in spite of its obvious and irrepressible technicality. Occasionally he renders it really amusing."

\section{The Meaning of Money}

I 5 th Impression

38. 6d. net.

"There can be no doubt that Mr Withers' book will supersede all other introductions to monetary science . . . readers will find it a safe and indispensable guide through the mazes of the Money Market."Financial Nerus.

\section{Poverty and Waste}

3s. 6d. net.

"The book views its subject from the advantageous position of an impartial observer, the respective cases for capital and labour, rich and poor, and producer and consumer being brought to the reader's attention in a convincingly logical manner."-Financial Times.

\section{War and Lombard Street} 3rd Edition

3s. 6ä. net.

"Carried out with the same happy touch of literary simplicity and wit combined with an expert knowledge of his subject which has given distinction and popular value to his preceding books. Nothing could be clearer or more enlightening for the general reader."-Times.

\section{International Finance}

3s. 8d. net.

"We heartily commend a timely work dealt with in popular and simple style, which, however, in no way detracts from its value as a standard financial work."-Morning Post.

JOHN MURRAY, ALBEMARLE STREET, LONDON, W. 1. 

Date Due

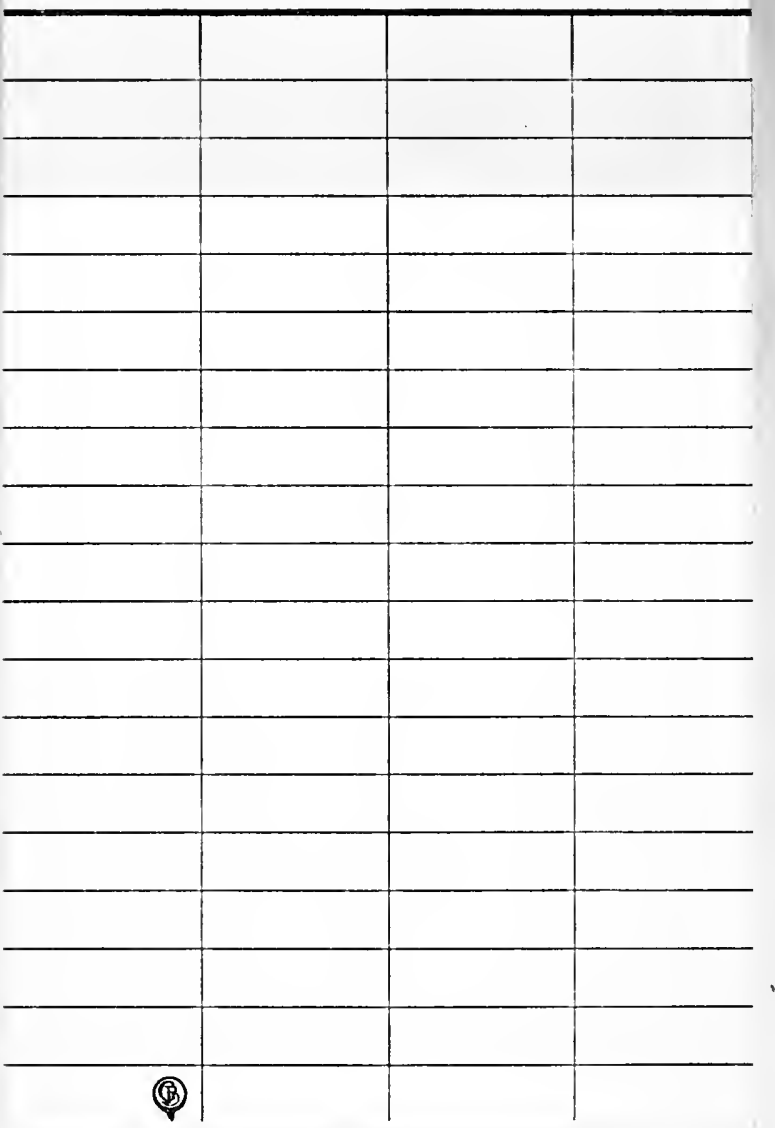


Charman, Sir S.J., ed. TITLE

\section{Labour and capital after the} พar.

DATE DUE BORPOWERGNAME

Charman, Sir S.J., ed.

Labour and capital after the var. 
